UNIVERSIDADE FEDERAL DO AMAZONAS - UFAM UNIVERSIDADE ESTADUAL DO AMAZONAS - UEA BIO INSTITUTO NACIONAL DE PESQUISAS DA AMAZÔNIA - INPA PROGRAMA DE PÓS-GRADUAÇ̃̃o EM BIODIVERSIDADE E BIOTECNOLOGIA DA AMAZÔNIA LEGAL - REDEBIONORTE

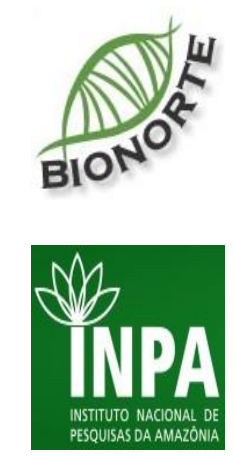

MARCONDE CARVALHO DE NORONHA

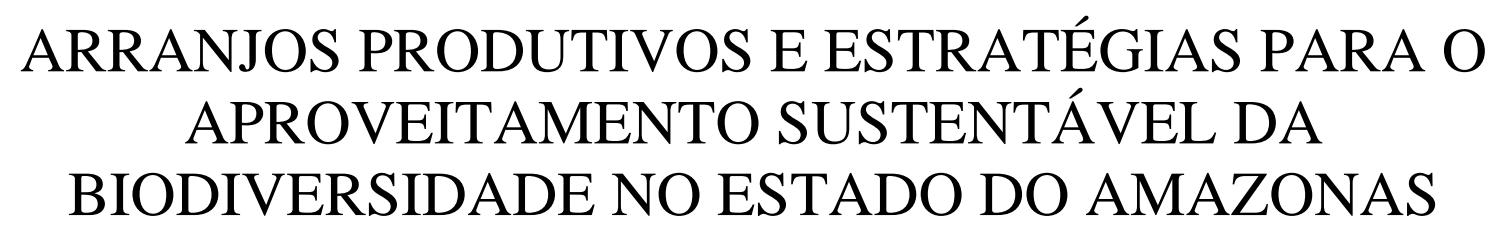

Novembro - 2018

Manaus - Amazonas - Brasil 
UNIVERSIDADE FEDERAL DO AMAZONAS - UFAM UNIVERSIDADE ESTADUAL DO AMAZONAS - UEA INSTITUTO NACIONAL DE PESQUISAS DA AMAZÔNIA - INPA PROGRAMA DE PÓS-GRADUAÇÃO EM BIODIVERSIDADE E BIOTECNOLOGIA DA AMAZÔNIA LEGAL - REDEBIONORTE

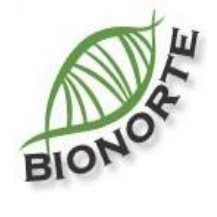

\section{ARRANJOS PRODUTIVOS E ESTRATÉGIAS PARA O APROVEITAMENTO SUSTENTÁVEL DA BIODIVERSIDADE NO ESTADO DO AMAZONAS}

Tese apresentada ao Programa de Pós Graduação em Biodiversidade e Biotecnologia da Amazônia Legal REDEBIONORTE como requisito para obtenção de Doutorado na área de concentração em 'Biodiversidade e Conservação' e linha de pesquisa em 'Gestão do Desenvolvimento Sustentável'.

Orientando: Marconde Carvalho de Noronha Orientadora: Profa. Dra. Ires Paula de Andrade Miranda Co-Orientadora: Profa. Dra. Michele Lins Aracaty e Silva.

Novembro - 2018

Manaus - Amazonas - Brasil 


\section{Ficha Catalográfica}

Ficha catalográfica elaborada automaticamente de acordo com os dados fornecidos pelo(a) autor(a).

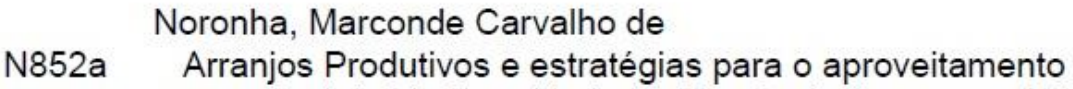
sustentável da biodiversidade no Estado do Amazonas / Marconde Carvalho de Noronha. 2018

110 f.: il. color; $31 \mathrm{~cm}$.

Orientadora: Ires Paula de Andrade Miranda Coorientadora: Michele Lins Aracaty e Silva Tese (Doutorado em Biodiversidade e Biotecnologia da Rede Bionorte) - Universidade Federal do Amazonas.

1. Arranjos Produtivos Locais. 2. APL de Fitoterápicos e Fitocosméticos. 3. Eficiência do desempenho. 4. Desenvolvimento econômico e social. I. Miranda, Ires Paula de Andrade II. Universidade Federal do Amazonas III. Título 


\section{MARCONDE CARVALHO DE NORONHA}

\section{"ARRANJOS PRODUTIVOS E ESTRATÉgIAS PARA O APROVEITAMENTO SUSTENTÁVEL DA BIODIVERSIDADE NO ESTADO DO AMAZONAS".}

Tese de doutorado apresentada ao Curso de Doutorado do Programa de Pós-Graduaçăo em Biodiversidade e Biotecnologia da Rede de Biodiversidade e Biotecnologia da Amazónia Legal, na Universidade do Estado do Amazonas. como requisito para obtençăo do titulo de Doutor em Biodiversidade e Conservação.

Orientador (a): Profa. Dra. Ires Paula de Andrade Miranda Co-orientador(a): Profa. Dra. Michele Lins Aracaty e Silva

Banca Examinadora:

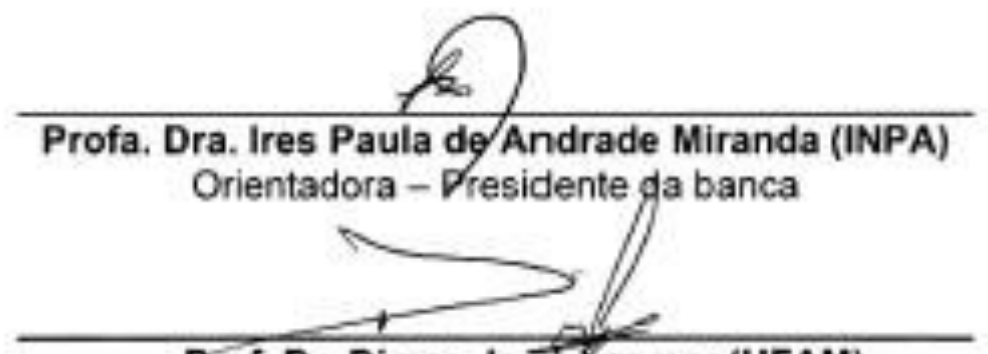

Prof. Dr. Dimas Joste Lasmar (UFAM) Membro

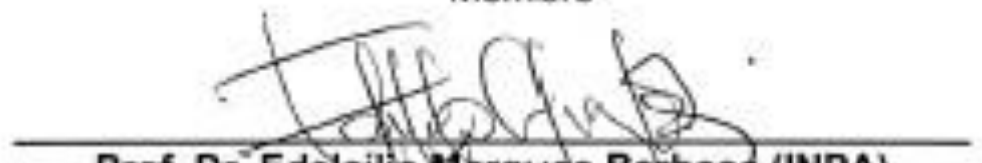

Prof. Dr. Edelcilia Afarques Barbosa (INPA) Membro

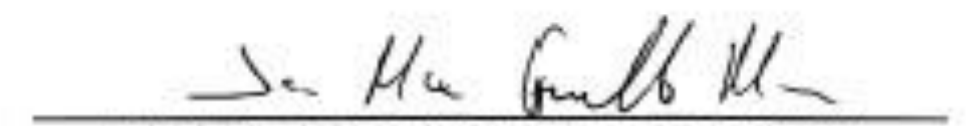

Prof. Dr. Jair Max Furtunato Maia (UEA)

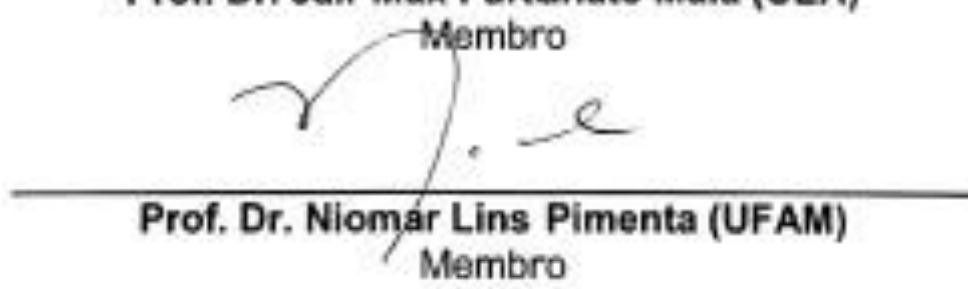

MANAUS - AMIAZONAS

Novembro/2018 


\section{DEDICATÓRIA}

Dedico esta tese ao nosso querido Pai eterno, força superior que rege toda a existência.

Aos meus pais, Leonardo Botelho de Noronha (in memoriam) e Terezinha Carvalho de Noronha, aprendizado inicial para o enfrentamento da vida.

À minha querida esposa Marcionília Santana de Noronha, por seu amor, companheirismo, dedicação e tolerância.

Aos meus filhos Paula, Marlon e Hiuri Noronha, meu neto Théo, meu genro Yuri Teixeira e minhas noras Poliana e Amanda, motivação e continuação de minha vida.

Ao meu tio Raymundo Botelho de Noronha, por todo o aval creditado à minha pessoa e por todo esforço empreendido em prol da criação do Sistema SECT/FAPEAM

Aos meus mestres do ICHL/UFAM aonde obtive a Licenciatura em Estudos Sociais, o Bacharelado em Ciências Econômicas e o Mestrado em Desenvolvimento Regional, pontos de referência para minha carreira profissional.

Ao Prof. Dr. Guajarino de Araújo Filho (in memoriam), ponto de incentivo para participar no doutorado da Rede Bionorte. 


\section{AGRADECIMENTOS}

À Universidade do Estado do Amazonas - UEA, instituição coordenadora regional do Polo Bionorte do Estado Amazonas por apoio no desenvolvimento do trabalho de tese.

À Universidade Federal do Amazonas - UFAM, então Coordenação Geral na época da minha inserção no doutorado dos cursos de pós-graduação da Rede Bionorte, pelo ingresso no doutoramento e ajuda sempre que solicitada.

Ao Instituto Nacional de Pesquisas da Amazônia - INPA pelo apoio oferecido para execução deste trabalho.

À Secretaria de Estado de Planejamento, Desenvolvimento, Ciência, Tecnologia e Inovação SEPLANCTI por possibilitar minha atuação no programa de doutorado.

À Fundação de Amparo à Pesquisa do Estado do Amazonas - FAPEAM e ao Diretor Técnico Dr. Décio Luiz Reis, pelo acesso ao banco de dados para consulta aos editais de subvenção, um dos objetivos do trabalho de pesquisa.

À Profa. Dra. Ires Paula Andrade Miranda, a quem tive o privilégio de ter como orientadora da tese, por sua amizade nos momentos mais desafiadores e por ter exercido um papel fundamental no planejamento e execução do trabalho, alinhando as ações de pesquisa.

À Profa. Dra. Michele Lins Aracati e Silva, pela co-orientação do trabalho, amizade, carinho e apoio na construção do modelo de acompanhamento com a literatura específica.

Ao Prof. Dr. Dimas José Lasmar, por sua valiosa colaboração quando integrou a banca da aula de qualificação.

Ao Prof. Dr. Spartaco Astolfi Filho, Coordenador Geral do PPG-Bionorte à época, pelo carinho e incentivo na participação do referido programa.

Ao Prof. Dr. Jair Max Furtunato Maia, Coordenador Estadual da Rede Bionorte Polo Amazonas, pela amizade, atenção e presteza dispensadas ao andamento das questões acadêmicas do curso.

À Profa. Dra. Patrícia Maia Correia de Albuquerque, Coordenadora Geral do PPG-Bionorte por sua atenção e dedicação na condução do curso de doutorado da Rede Bionorte.

À Profa. Dra. Fátima Bigi, Coordenadora do Banco de Dados do PPG-Bionorte, pela amizade e incentivo no trabalho dos Arranjos Produtivos.

Aos funcionários das coordenações Geral e Estadual do Programa Bionorte, pela colaboração e eficiência nos trâmites administrativos durante o período do meu curso de doutorado.

A todos que diretamente ou indiretamente contribuíram para a realização deste trabalho. 


\section{LISTA DE GRÁFICOS}

Gráfico 1 - Ações Realizadas e Previstas no APL de Fitoterápicos e Fitocosméticos ........ 56

Gráfico 2 - Viabilização financeira nas ações realizadas .............................................. 57

Gráfico 3 - Viabilização financeira nas ações previstas ................................................ 57

Gráfico 4 - Resultados das ações realizadas - APL de Fitoterápicos e Fitocosméticos ..... 58

Gráfico 5 - Resultados das ações previstas - APL de Fitoterápicos e Fitocosméticos ....... 58

Gráfico 6 - Item relacionado por ações - APL de Fitoterápicos e Fitocosméticos ............ 58

Gráfico 7 - Número de parcerias nas ações - APL de Fitoterápicos e Fitocosméticos ....... 59

Gráfico 8 - Conhecimento do instrumento APLs ....................................................... 62

Gráfico 9 - Momento de inserção da empresa no instrumento APL ................................ 63

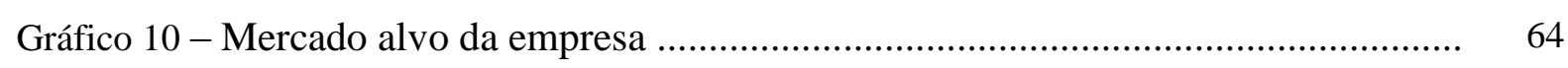

Gráfico 11 - Existência de área específica na empresa para lidar com o tema APL ......... 65

Gráfico 12 - Escolha sobre a área para desenvolver um projeto/parceria em APL .......... 66

Gráfico 13 - Forma como empresas, governos e demais entidades apoiam o negócio ...... 67

Gráfico 14 - Relacionamento da empresa com as demais empresas do setor .................. 68

Gráfico 15 - Relacionamento entre a empresa e a governança do arranjo ...................... 68

Gráfico 16 - Aquisição da matéria prima para o(s) produto(s) da empresa .................... 70

Gráfico 17 - Participação dos fornecedores no desenvolvimento dos negócios .............. 70

Gráfico 18 - Qualificação para acesso ao mercado .......................................................

Gráfico 19 - Aumento percentual no nível de produtividade ......................................... 72

Gráfico 20 - Visibilidade da empresa pelo mercado e sociedade em geral .................... 72

Gráfico 21 - Modelo organizacional utilizado na empresa ........................................... 73

Gráfico 22 - Informatização dos processos administrativos ......................................... 74

Gráfico 23 - Tecnologia de produção implantada na empresa .................................... 74

Gráfico 24 - Participação no PAPPE/FAPEAM de Subvenção aos APLS do Amazonas 76

Gráfico 25 - Obtenção de créditos/financiamentos complementares ............................... 77

Gráfico 26 - Geração de emprego e renda propiciado no instrumento APL às empresas 78

Gráfico 27 - Famílias beneficiadas com o projeto apresentado à Subvenção ................. 78

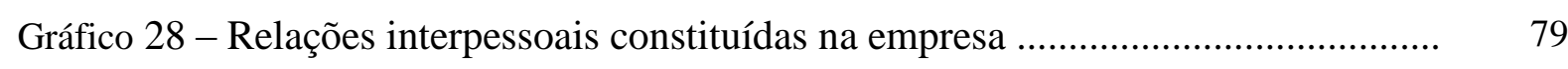

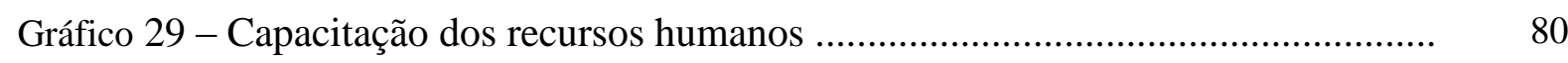

Gráfico 30 - Nível de conhecimento técnico adquirido pelos colaboradores ................. 81

Gráfico 31 - Nível de conhecimento e treinamento gerencial da empresa ...................... 81 


\section{LISTA DE QUADROS}

Quadro 1 - Etapas propostas nos projetos para validação das plantas medicinais.

Quadro 2 - Mapeamento dos APLS no Amazonas..................................................... 30

Quadro 3 - Avanços na medição de desempenho ........................................................ 38

Quadro 4 - Casos recentes de sucesso de APLs no Brasil............................................. 40

Quadro 5 - Variáveis de eficiência e eficácia do desempenho selecionadas ................. 43

Quadro 6 - Variáveis selecionadas para a medição do desempenho do APL ................ 52

Quadro 7 - Empresas Pesquisadas ....................................................................... 53

Quadro 8 - Modelo de estrutura para a construção da Matriz SWOT .......................... 54

Quadro 9 - Área de Concentração, Número de Empresas e Investimentos dos Projetos do PAPPE: edições 2004 e 2008 ............................................................... 61

Quadro 10 - Cadeias Produtivas - familiares ou empresariais ................................... 83

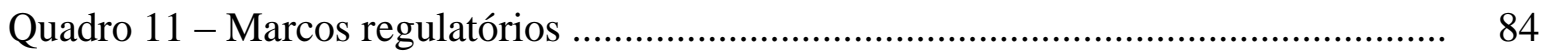

Quadro 12 - Mecanismo de atração de investidores e empresas ................................. 84

Quadro 13 - Capacitação de recursos humanos ...................................................... 85

Quadro 14 - Insumos para a produção em larga escala - limitações, oportunidades ...... 85

Quadro 15 - Desenvolvimento de produtos e processos biotecnológicos ...................... 86

Quadro 16 - Cadeias produtivas, geração de emprego e renda ...................................... 86

Quadro 17 - Capacitação de recursos humanos e assistência técnica ........................... 87

Quadro 18 - Mecanismos de atração de investidores e empresas ................................. 87

Quadro 19 - Produção de insumos em larga escala ................................................. 88

Quadro 20 - Modelo alvo do PAPPE-Subvenção: Responsabilidade Social ........... 91

Quadro 21 - Modelo alvo do PAPPE-Subvenção: Responsabilidade Ambiental ........ 91 


\section{LISTA DE FIGURAS}

Figura 1 - Amazônia Legal no Brasil ................................................................................ 19

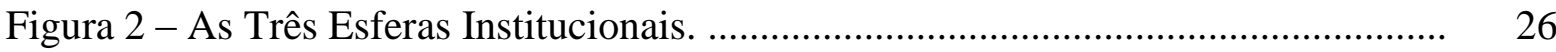

Figura 3 - Estrutura do Núcleo Estadual dos APLs a partir do modelo alvo ................. 29

Figura 4 - Áreas propícias para investimentos em Fitoterápicos e Fitocosméticos ........ 32

Figura 5 - Encadeamento Produtivo …................................................................. 37

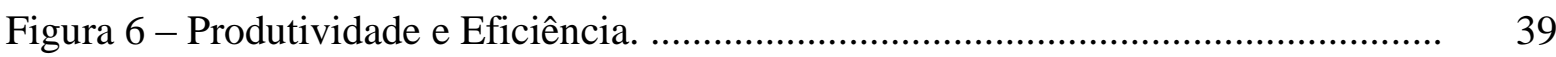

Figura 7 - Perspectiva de gestão da medição de desempenho para APLs ..................... 41

Figura 8 - Alguns indicadores de desempenho para APLs ......................................... 42

Figura 9 - Gestão do desempenho de APLs e a Rede de Cooperação ........................... 44

Figura 10 - Perspectiva de gestão de APLs com a SWOT (FOFA) …......................... 44

Figura 11 - Modelo de Gestão de Desempenho para APLs ...........................................

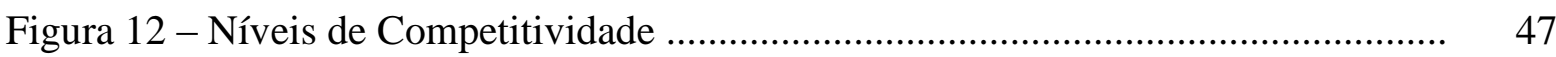

Figura 13 - Estratégia 1 - Meio Ambiente e Regionalização ....................................... 48

Figura 14 - Estratégia 4 - Formação de Recursos Humanos ........................................ 49

Figura 15 - Estratégia 5 - Ciência e Tecnologia ........................................................... 50

Figura 16 - Modelo de gestão do desempenho para a superação de barreiras do APL ... 97 


\section{LISTA DE TABELAS}

Tabela 1 - Orçamento do projeto Desenvolvimento de dois produtos Fitoterápicos e um Fitocosmético a partir de espécies Amazônicas

Tabela 2 - Programas FAPEAM/MCTI/FINEP interconectados com os APLs 


\section{LISTA DE ABREVIATURAS}

ABIHPEC - Associação Brasileira da Indústria de Higiene Pessoal, Perfumaria e Cosméticos AFEAM - Agência de Fomento do Estado do Amazonas

ANVISA - Agência Nacional de Vigilância Sanitária

CIDE - Centro de Incubação e Desenvolvimento Empresarial

CIEAM - Centro da Indústria do Estado do Amazonas

DFA/AM - Delegacia Federal da Agricultura no Amazonas

EMBRAPA - Empresa Brasileira de Pesquisas Agropecuárias

FAEA - Federação da Agricultura e Pecuária do Estado do Amazonas

FAPEAM - Fundação de Amparo à Pesquisa do Estado do Amazonas

FIEAM - Federação das Indústrias do Estado do Amazonas

FUCAPI - Fundação Centro de Análise, Pesquisa e Inovação Tecnológica

FVS - Fundação de Vigilância em Saúde do Estado do Amazonas

IBAMA - Instituto Brasileiro do Meio Ambiente e dos Recursos Naturais Renováveis

IDAM - Instituto de Desenvolvimento Agropecuário do Amazonas

INPA - Instituto Nacional de Pesquisas da Amazônia

IPAAM - Instituto de Proteção Ambiental do Estado do Amazonas

MCTI - Ministério da Ciência, Tecnologia e Inovação

MDIC - Ministério do Desenvolvimento, Indústria e Comércio Exterior

MMA - Ministério do Meio Ambiente

PAPPE - Programa de Apoio à Pesquisa em Pequenas Empresas

PIM - Pólo Industrial de Manaus

PMM - Prefeitura Municipal de Manaus

SDS - Secretaria de Estado do Meio Ambiente e Desenvolvimento Sustentável

SEBRAE/AM - Serviço Brasileiro de Apoio à Micro e Pequenas Empresas do Amazonas

SENAI - Serviço Social da Indústria SESI; Serviço Nacional de Aprendizagem Industrial

SEMDEL - Secretaria Municipal de Desenvolvimento Econômico Local

SEPLANCTI - Secretaria de Estado de Planejamento, Desenvolvimento, Ciência, Tecnologia e Inovação

SEPROR - Secretaria de Estado da Produção Rural

SUFRAMA - Superintendência do Desenvolvimento da Zona Franca de Manaus

UEA - Universidade do Estado do Amazonas

UFAM - Universidade Federal do Amazonas

ZFM - Zona Franca de Manaus 


\section{RESUMO}

A presente tese foi desenvolvida a partir de um estudo sobre o resultado de investimentos do setor público no Arranjo Produtivo Local de Fitoterápicos e Fitocosméticos, com foco no programa da FAPEAM intitulado PAPPE-Subvenção, enquanto modelo alvo para o desenvolvimento econômico no Estado do Amazonas e, por conseguinte, do aproveitamento da biodiversidade, em especial no que tange às experiências decorrentes da participação de empresas de base biotecnológica (fitoterápicos, fármacos, fitocosméticos, entre outras). O estudo foi caracterizado quanto à natureza como uma pesquisa básica, ressaltando o instrumento de gestão em referência, envolvendo stakeholders, tais como, bioindústrias, a partir do modelo alvo apropriado para o aproveitamento comercial da floresta e o desenvolvimento social na Amazônia. Os parâmetros abordados incluíram na parte empírica, a análise preliminar resultante da aplicação de questionários às empresas, com destaque para suas percepções sobre os principais impactos para o desenvolvimento econômico. Utilizou-se para a sistematização das informações dos clusters, a matriz de importância da eficiência do desempenho e a matriz SWOT, para a abordagem do diagnóstico dos componentes, que respondeu e apontou se esse modelo alvo de APLs tende ou não ao êxito e, destarte se tende ao desenvolvimento social e da eficiência do desempenho. Uma premissa foi analisar a interação entre doador e receptor da organização produtiva e a governança dos setores selecionados, enquanto instrumento de apoio à bioeconomia no Estado do Amazonas. Constatou-se como resultado da investigação, que o modelo de APL utilizado como estratégia para o atendimento da alavancagem e responsabilidade socioeconômica das micro e pequenas empresas, requer uma maior e melhor interação institucional. Quanto à cooperação entre os clusters, no sentido de geração de emprego e renda, a formação de recursos humanos do ponto de vista tecnológico, entre outros, necessita maior capacitação em gestão da inovação e o desenvolvimento de competências pessoais e profissionais, para o alcance de novas estruturas e processos organizacionais.

Palavras-chave: Arranjos Produtivos Locais, Eficiência do Desempenho, Desenvolvimento Econômico e Social. 


\begin{abstract}
The present thesis proposes a study about the results of investments of public sector in a cluster phytotherapeutics and phytocosmetics, as a target model for sustainable development in the State of Amazonas and, consequently, for the conservation of biodiversity, especially with regards to the resulting experiences (phytotherapeutics, pharmaceuticals and phytocosmetics), in the FAPEAM Program entitled PAPPE-Subsidy. The study it's characterized in nature as a basic research, highlighting the management tool in question, involving stakeholders, such as bio-industries, from the appropriate target model for the commercial use of the forest and the sustainability of traditional communities in the Amazon. The thesis deals with the theoretical framework built up from bibliographical and documentary research and, in the empirical part, the preliminary analysis resulting from interviews with the protagonists, the culmination of the field research with representatives of companies, researchers, communities and leaders of the public power, highlighting their perceptions about the main impacts for sustainable regional development. It's used for the systematization of information, the matrix of importance of economic efficiency and the SWOT matrix, to approach the diagnosis of the components of the study, which should answer and point out to what extent this target model of APLs is successful or not, this is based on the foundations of sustainable development and economic efficiency. One premise was to analyze interactively between the donor and recipient of the productive organization and the governance of the selected sectors, as a tool to support the bioeconomy in the State of Amazonas. As a result of the research, the APL model used as a strategy for meeting the economic leverage and socio-environmental responsibility of micro and small enterprises requires a greater and better institutional interaction. As for the cooperation between the clusters, in the sense of generating employment and income, the training of human resources from the technological point of view, among others, requires greater capacity in innovation management and the development of personal and professional competences, to reach new organizational structures and processes.
\end{abstract}

Key words: Local Production Arrangements, Economic Efficiency, Development Economic and Social. 


\section{SUMÁRIO}

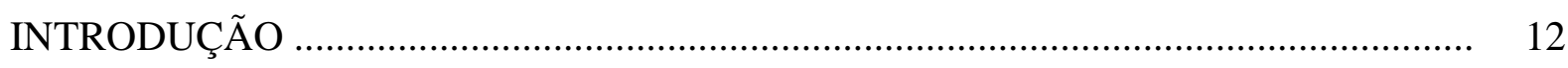

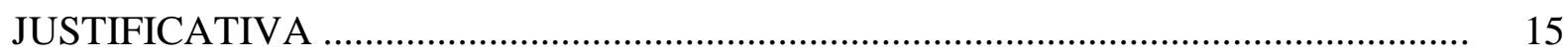

FORMULAÇÃO DO PROBLEMA DE PESQUISA …………………….................... 16

OBJETIVO GERAL E OBJETIVOS ESPECÍFICOS …………………………......... 17

LIMITAÇÕES DO ESTUDO ................................................................................ 18

1. REFERENCIAL TEÓRICO

1.1 RECURSOS NATURAIS, CONSERVAÇÃO E BIODIVERSIDADE ....................... 19

1.2 O MODELO DE ARRANJO PRODUTIVO LOCAL - APL ……………………….... 23

1.2.1 Implantação do Núcleo Estadual de APL - NEAPL ........................................ 29

1.2.2 Elaboração do Plano de Desenvolvimento Preliminar - PDP .......................... 31

1.2.3 O APL de Fitoterápicos (ou Fármacos) e Fitocosméticos ................................ 32

1.3 DESENVOLVIMENTO SOCIOECONÔMICO X SUSTENTABILIDADE ............ 34

1.4 EFICIÊNCIA DO DESEMPENHO .................................................................... 38

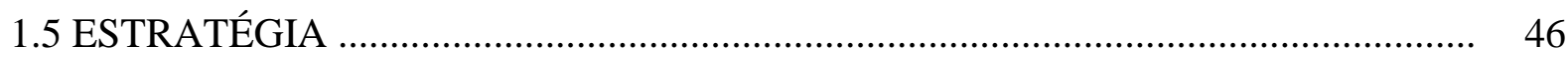

2. METODOLOGIA

2.1 Classificação da Pesquisa ................................................................................ 51

2.2 Etapas da Pesquisa …………………………………............................. 51

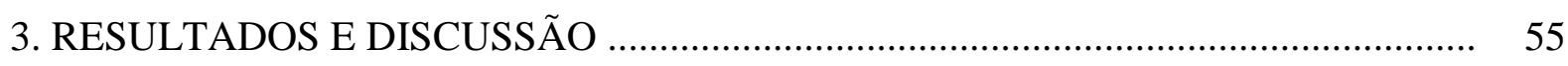

3.1 DAS AÇÕES DO PROGRAMA PLATAFORMAS TECNOLÓGICAS ATÉ A ADOÇÃO DA ESTRATÉGIA DE APL ………………………………………….... 55

3.2 DA PESQUISA DO DESEMPENHO DAS EMPRESAS …...................................... 60

3.3 DA MATRIZ SWOT DE IMPORTÂNCIA DO DESEMPENHO .............................. 82

3.4 DOS RELATÓRIOS DAS EMPRESAS ……………………………………….... 89

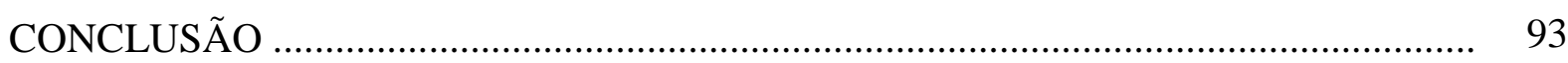

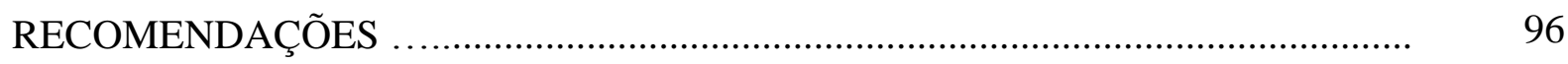

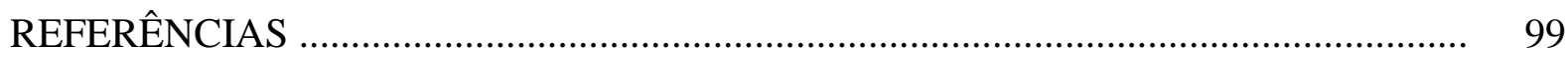

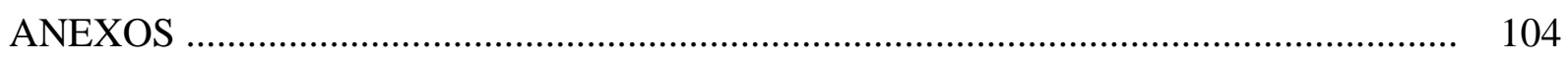




\section{INTRODUÇÃO}

$\mathrm{O}$ atual modelo econômico e ambiental amazonense tem sido bastante questionado, considerando o grande potencial em sua rica biodiversidade, o que leva a sociedade a vislumbrar um outro cenário possível, onde os recursos gerados não sejam provenientes exclusivamente do Polo Industrial de Manaus com suas transnacionais, que nada mostram ao mercado mundial das verdadeiras riquezas da Amazônia e o quanto sua diversidade biológica poderia proporcionar de retorno socioeconômico para a região.

O desenvolvimento nos últimos anos tem se traduzido em pequenos ganhos sociais para a maioria da população amazonense, em especial, àquela que vive no interior do Estado do Amazonas. Mesmo nas principais cidades que contam com razoáveis equipamentos e serviços sociais básicos, estes ainda não são suficientes para atender às demandas locais e regional.

Outra inquietação é o padrão de desenvolvimento em curso no território amazonense, catalisada pelo simpósio da Organização das Nações Unidas - ONU, conhecido como Rio 92, em que se acatou uma agenda positiva de atividades orientadas para a preservação e conservação da floresta, com o financiamento de países mais desenvolvidos. Apesar de tímidos em termos dos desafios existentes, esses esforços sinalizam para a necessidade de incluir a dimensão do aproveitamento racional nos programas e projetos de desenvolvimento de qualquer natureza.

Assim, o meio científico tem apresentado modelagens estratégicas e tecnológicas plausíveis para evitar a perda brutal da maior biodiversidade do planeta com o atual modelo. $\mathrm{O}$ avanço na investigação científica, com participação dos principais agentes econômicos, se constitui em um forte apelo para alavancar novos produtos nos últimos anos, a ponto de despertar no protagonismo local iniciativas empreendedoras em prol do desenvolvimento econômico e social.

Por muito tempo o Amazonas ficou conhecido pelo extrativismo, cujos produtos durante muitos anos foram a base de sua economia. Ainda hoje a população rural tem nesta atividade uma fonte de renda. Os produtos estão dispersos por todo o Estado como, por exemplo, a andiroba, a copaíba, o cumaru, entre outros. A população rural desenvolve esta atividade de forma tradicional, sobretudo na calha dos rios Madeira, Jutaí e Purus.

Estes simples exemplos, que por um lado expressam a forte tendência para o uso de produtos naturais da Amazônia e intenções de investimentos, por outro, não apresentam um indicativo maior no mercado para níveis apreciáveis no curto prazo. Entre os principais 
produtos demandados figuram xarope, chá, unguento, emplastro, tintura, cápsula, pomada, creme, loção.

Como resultado da visão prospectiva de um grupo representativo de diversos segmentos sociais, da consciência de cidadania, comprometimento e inabalável confiança na possibilidade de concretização de um ideal, consolidou-se uma visão em prol do desenvolvimento econômico com base no aproveitamento racional dos recursos naturais.

Eis que o modelo de Arranjo Produtivo Local - APL foi pensado para implementar pesquisas em CT\&I neste mercado, visando a criação e/ou inovação de produtos da biodiversidade para diversas demandas. O trabalho com APL se iniciou em 2001 no Programa Plataformas Tecnológicas do MCT, pautado nos estudos da SUFRAMA voltado às potencialidades regionais para gerar emprego e renda em diversos setores econômicos.

Esta fase inicial pode ser considerada embrionária para o APL em estudo e, portanto, fundamental, pois incluiu sensibilização e mobilização de diversas instituições. Em seguida houve a migração de sua gestão do MCT para o MDIC, por designação do Governo Federal em 2003, sem romper com as conquistas do Plataformas Tecnológicas, mas, ao contrário, promovendo uma segunda fase marcada pelo acréscimo de articulação e estruturação, em virtude da mudança do foco em CT\&I, voltando-se desta vez ao fortalecimento comercial do APL com possível alavancagem de novos produtos para os mercados nacional e internacional.

A fase de 2006 até 2011, que coincide com a criação de núcleos estaduais por todo o Brasil, foi marcada por inúmeras ações de sensibilização e articulação e, ao seu final, a coordenação do Núcleo de APLs no Amazonas migrou da SEPLAN para a Agência de Desenvolvimento Sustentável - ADS, por determinação do novo governo estadual à época, como uma medida para dar maior operacionalidade comercial segundo orientação do próprio governo federal via Grupo de Trabalho Permanente - GTP para todo o país.

É nítido que para o APL de Fitoterápicos e Fitocosméticos, a região tem grande potencial para produção e exportação de bioprodutos em geral, dado o grande potencial existente da biodiversidade, entretanto carece de uma política específica voltada para o desenvolvimento endógeno e socioeconômico no sentido de se poder promover a criação de uma nova base econômica, com a exploração de culturas produtivas para uso na bioindústria no Estado do Amazonas. Aparentemente os desafios se concentram em obstáculos tecnológicos, uma vez que não se dispõe de massa crítica suficientemente qualificada e parque industrial capacitado para desenvolver Ciência, Tecnologia e Inovação - CT\&I.

Para a compreensão dos investimentos e o custo-benefício das ações empreendidas no APL em foco, foi proposto um objetivo geral para analisar resultados dos investimentos do 
setor público no APL, instrumento de planejamento e gestão de incentivos governamentais, como subvenções, concebidas para auxiliar setores da biodiversidade no Estado do Amazonas. A pesquisa se volta ao APL de Fitoterápicos e Fitocosméticos, considerando as empresas beneficiadas por tal incentivo.

Além desta breve contextualização e caracterização do modelo alvo do APL estudado, a tese apresenta referencial teórico, análise dos resultados preliminares e considerações sobre o estudo. No referencial teórico são apresentados conceitos e pontos de vista de autores renomados sobre o tema, como também os diversos aspectos que envolvem o problema da gestão do aproveitamento comercial da biodiversidade no Amazonas.

Trata-se de uma revisão da literatura que proporcione familiaridade com o assunto, por pensar em uma hipótese que busca previsibilidade às possíveis situações em que os segmentos e o meio cultural possam se encontrar, utilizando-se de uma abordagem qualitativa e quantitativa, pois, considera-se que exista uma relação dinâmica entre o mundo real e o sujeito.

A operacionalização das informações tem origem nas consultas realizadas por meio de questionamentos junto às empresas do APL de Fitoterápicos e Fitocosméticos participantes nas edições do PAPPE Subvenção, coordenadas pela FAPEAM. Para a análise foram selecionadas 16 (dezesseis) variáveis de eficiência do desempenho utilizadas na avaliação de outros modelos de APLs. Também os clusters serão mapeados de acordo com a interconexão das empresas do APL com os atores acadêmicos, dos bancos de dados institucionais.

O trabalho de tese caracteriza-se como uma pesquisa básica e exploratória, na medida que tem a finalidade de gerar conhecimentos novos úteis para o avanço da ciência e auxiliar as tomadas de decisões nas políticas públicas de fomento ao desenvolvimento econômico e social. 


\section{JUSTIFICATIVA}

O estudo proposto nesta tese se justifica primeiramente em função do modelo alvo do APL de Fitoterápicos e Fitocosméticos e estratégias, considerando a atividade extrativista na Amazônia e no crescimento anual desenfreado da degradação florestal que vem acontecendo na região e, consequentemente, no Estado do Amazonas, encerrando um problema complexo, que requer atenção especial, na medida em que envolve interesses públicos e privados, os quais tem deixado muito a desejar no que tange ao planejamento estratégico para a gestão do aproveitamento dos recursos florestais.

Em segundo lugar, a partir do notório interesse científico e econômico na biodiversidade amazônica quanto ao potencial de suas espécies vegetais e, à necessidade de sua conservação, no contexto do APL, enquanto instrumento de aproveitamento racional dos recursos da floresta levando-se em conta a interação entre os agentes empresa, governo e academia. Sabe-se que o assunto tem sido alvo de muitas pesquisas.

Em terceiro lugar, em virtude de uma maior exposição do tema da biodiversidade, quando do levantamento de informações para o planejamento do desenvolvimento de cadeias produtivas promissoras no Amazonas, o que oportuniza uma discussão sobre os resultados do APL, assim como, a existência ou não de impactos socioeconônimicos.

Sendo assim, percebe-se a necessidade de aprofundar os estudos quanto aos resultados obtidos até o momento da utilização do modelo alvo para o aproveitamento da floresta no segmento selecionado, com foco em uma análise da importância deste instrumento e em que proporção atende ou não aos fundamentos do desenvolvimento socioeconômico. 


\section{FORMULAÇÃO DO PROBLEMA DE PESQUISA}

Nesta pesquisa a pergunta a ser respondida é se o APL em estudo e suas estratégias, adotadas como instrumento de investimento para aproveitar os recursos naturais da biodiversidade no Estado do Amazonas, apresentaram eficiência de desempenho e, consequentemente, benefícios para a sociedade. Portanto, coloca-se como desafio nesta tese, a produção de um estudo que possa apurar o modelo alvo, a partir do entendimento de que este problema é uma questão a ser resolvida e que se torna objeto de discussão devido a grande necessidade de corrigir os desequilíbrios produzidos nas últimas décadas, na situação socioeconômico entre a capital e o interior do Estado, como as grandes diferenças no nível de emprego e renda, distribuição da população, infraestrutura econômica, bem estar social, e outras questões. 


\section{OBJETIVOS}

\section{- Geral}

Analisar o modelo de Arranjos Produtivos Locais e estratégias de eficiência de desempenho nos resultados dos investimentos do setor público, como um instrumento de gestão para a biodiversidade do Estado do Amazonas.

\section{- Específicos}

a) Descrever o modelo alvo de investimento do setor público do Arranjo Produtivo Local de Fitoterápicos e Fitocosméticos.

b) Mapear os 'clusters' de empresas e instituições interconectadas para a subvenção do APL de Fitoterápicos e Fitocosméticos.

c) Apontar em que medida o modelo alvo de investimento atendeu às políticas públicas com base na responsabilidade social e econômica.

d) Recomendar um modelo de acompanhamento que leve ao conhecimento dos resultados e sua utilização para a superação de barreiras ao desenvolvimento socioeconômico do APL de Fitoterápicos e Fitocosméticos. 


\section{LIMITAÇÕES DO ESTUDO}

A tese limita-se a uma análise dos resultados preliminares dos investimentos públicos no setor econômico de fitoterápicos (ou fármacos) e fitocosméticos por meio do Arranjo Produtivo Local e suas estratégias, como instrumento que possa agregar mais conhecimento para o processo de fortalecimento de cadeias produtivas que utilizam a biodiversidade, com modelo adequado para o desenvolvimento econômico e social.

O trabalho proposto por esta pesquisa limita-se, portanto, ao diagnóstico do nível de atuação das empresas nos aspectos pertinentes a sua participação como membro de um arranjo produtivo local, considerando-se assim as micro e pequenas empresas que fazem parte deste tipo de organização. Outros aspectos necessários ao desenvolvimento das empresas em geral podem ser encontrados na literatura, com foco no desenvolvimento individual da empresa.

Da relação doador receptor, algumas empresas selecionadas para a investigação podem não retornar aos contatos via eletrônica (e-mail e/ou fone) e, no que tange a ánalise de relatórios das empresas investigadas que participaram do programa de subvenção na FAPEAM, pode acontecer restrições ao acessar o relatório de algumas pelo fato de não ser localizado em tempo hábil.

A aplicação do trabalho de pesquisa restringe-se ao nível de diretoria (ou gerencial), não abrangendo o chão de fábrica ou setores específicos, por tratar-se de questões que requerem uma visão abrangente da empresa, expectativa que estima-se que os entrevistados deste nível da organização atendam. 


\section{REFERENCIAL TEÓRICO}

\subsection{RECURSOS NATURAIS, CONSERVAÇÃO E BIODIVERSIDADE}

A Amazônia ainda se apresenta como o maior bloco (aproximadamente 5,4 milhões de $\mathrm{km}^{2}$ ) de vegetação tropical remanescente e contínua do mundo e mais de $80 \%$ de sua extensão ainda se encontra preservada. O Brasil abriga $60 \%$ desta riqueza, como enfatizado na Figura 1. A região é também considerada berço da biodiversidade ${ }^{1}$ planetária, abrigando mais de $20 \%$ das espécies terrestres conhecidas e se constitui como peça fundamental para o equilíbrio climático regional e global (MALHI et al, 2008).

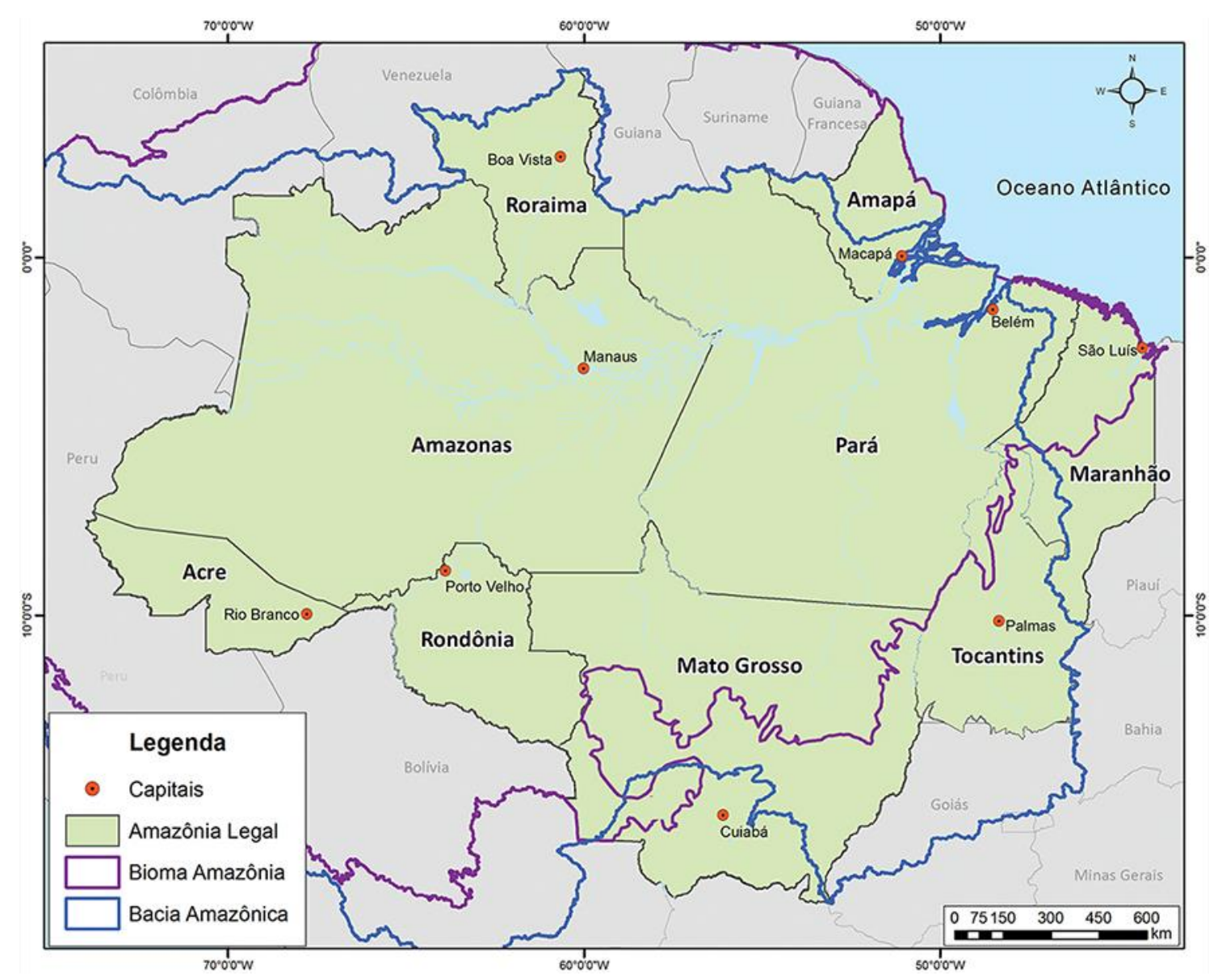

Figura 1 - Amazônia Legal no Brasil.

Fonte: Instituto Brasileiro de Geografia e Estatística - IBGE.

Levada a aceitar a relevância da questão ambiental, considerando as ameaças sobre a vida na Terra e a tendência de extinção de várias espécies, a visão humana vem sofrendo

\footnotetext{
${ }^{1}$ Biodiversidade ou diversidade biológica é um conjunto de todos os organismos vivos e suas interações e processos no âmbito dos ecossistemas. Representa variedade de formas de vida, dentro de uma espécie, no ecossistema, bioma ou do planeta, daí ser vital a integridade dos ecossistemas, dado que em boa parte da existência humana não houve preocupação com a sua conservação, consequentemente com extinção dos recursos naturais (Convenção sobre Diversidade Biológica, 1992).
} 
mudanças conceituais sobre a preservação da natureza nos últimos anos, da ênfase nos ecossistemas à ênfase na alteridade ${ }^{2}$ homem e natureza (MACE, 2014). Para Muden (2013), a dinâmica do uso da Amazônia, vem se traduzindo numa superexploração da floresta, o que traz efeitos devastadores sobre os ecossistemas e a sociedade.

Dias (2011) enfatiza que entre as décadas de 1940 a 1980, diversos acidentes com impacto global, levam à reflexões sobre as fragilidades ambientais e resultados dos modelos de desenvolvimento perseguidos até hoje. Dentre esses grandes acidentes, Dias destaca: derramamento de mercúrio na baia de Minamata-Japão, 1956; naufrágio do petroleiro Torrey Canyon, sul da Inglaterra, 1967; vazamento de gases letais, Bhopal-Índia, 1984; acidente nuclear de Chernobyl e o vazamento de petróleo do Exxon Valdez na América do Norte.

Do modo como é feito, o desenvolvimento não pode ser universalizado e essa idéia tem sido responsável por desviar as atenções da missão básica de identificar necessidades humanas vitais e possibilidades que abre ao avanço da ciência, para concentrá-las em propósitos abstratos como investimentos, exportações, crescimento do PIB, dentre outros. A culminância tem sido a busca por padrões de consumo e estilos de vida que levam, naturalmente, ao rompimento e aos caos e coloca a sociedade exposta a um colapso global (ENRÍQUEZ, 2008).

O Brasil sediou uma importante conferência sobre meio ambiente, a ECO-92, com o objetivo de encontrar medidas que permitissem o desenvolvimento socioeconômico aliado à conservação da natureza. Foi por intermédio da Agenda 21, principal produto da conferência, que este assunto passou para a agenda global, posto que ajudou a difundir questões ambientais nacionais e internacionais. Assim, buscou-se conscientizar nações ricas a ajudarem os países em desenvolvimento na implementação de uma economia sustentável (MERICO, 2002).

Segundo a Convenção da Diversidade Biológica - CDB de 1992, a biodiversidade da Amazônia possui um extraordinário patrimônio genético ${ }^{3}$, que deve ser estudado intensivamente, na medida em que os recursos naturais renováveis com valor econômico seriam preservados quando usados. A conjugação biodiversidade, biotecnologia e Amazônia pode contribuir para salvar a região de eventuais ações aquém da preservação. Partindo da premissa de que os governos devem proteger porque tem valor potencial via biotecnologia, a Medida Provisória 2186-16/2001, converte a biodiversidade de bem comum a patrimônio nacional. Porém, ela continua sendo perdida, fato observado nas conferências da ONU, pois, conclui que o sistema econômico não muda por tratado ambiental (SOUZA et al, 2015).

\footnotetext{
2 Concepção que parte do pressuposto de que todo o homem social interage e interdepende de outros indivíduos. Assim, como muitos cientistas afirmam, a existência do "eu-individual" só é permitida mediante um contato com o outro, que em uma visão expandida se torna o Outro - a própria sociedade diferente do indivíduo (MACE, 2014).

3 Informação de origem genética contida nos seres vivos, princípios ativos, proteínas, enzimas... (MMA, 2015).
} 
É nítido que a degradação não está destruindo somente a biodiversidade, mas, também causa ruptura no tecido social e qualidade de vida das comunidades que interagem com a floresta, produzindo saberes, mitos e crenças transmitidos às futuras gerações, caracterizando o Conhecimento Tradicional Associado - $\mathrm{CTA}^{4}$. Souza et al (2015) acrescenta que os conhecimentos indígenas, podem contribuir para o desenvolvimento, porém, é necessário que esses temas se tornem prioridade na agenda da Ciência, Tecnologia e Inovação regional e local.

Evidentemente, o uso racional dos recursos naturais é incompatível com o jogo sem restrições das forças de mercado. Os mercados são por demais míopes para transcender os curtos prazos e cegos para quaisquer considerações que não sejam lucros e eficiência smithiana $^{5}$ de alocação de recursos (SACHS, 2002). Esta situação remete a ideia de que:

Necessitamos, portanto, uma abordagem holística e interdisciplinar, na qual cientistas
naturais e sociais trabalhem juntos em favor do alcance de caminhos sábios para o uso
e aproveitamento dos recursos da natureza respeitando a sua diversidade. Conservação
e aproveitamento racional da natureza devem andar juntos. O uso produtivo não
necessariamente precisa prejudicar o meio ambiente ou destruir a diversidade, se
houver consciência de que todas as atividades econômicas estão fincadas no ambiente
natural (SACHS, 2002).

A relação da biodiversidade amazônica com o APL em estudo se dá na associação do extrativismo às populações da floresta na obtenção de insumos para empresas tradicionais de cosméticos ou especializadas em produtos naturais, como produtos fitoterápicos, com produção arcaica em pequena escala, que exige novas técnicas. Outra forma se dá por bioprospecção de moléculas, pautada na sintetização química, muito semelhante à desenvolvida pela indústria farmacêutica, o que requer a institucionalização da coleta da flora, para se evitar a biopirataria e/ou a extinção das espécies incorporadas ao processo de produção (SEPLAN, 2013).

Citando um estudo desenvolvido pelo Núcleo de Estudos e Pesquisa em Inovação NEPI em 2006 para o Centro de Gestão e Estudos Estratégicos - CGEE, Lasmar e Santos (2007), destacam sobre a biodiversidade da Amazônia que:

[...] seus recursos constituídos de genes, moléculas e microrganismos que, por seu potencial de aplicação, tem crescido em importância, pois são elementos que servem como matéria prima para o desenvolvimento de produtos de significativo potencial econômico, especialmente produtos biotecnológicos. Embora em graus diferenciados, são utilizados nas seguintes áreas: alimentos - incluindo os suplementos alimentares denominados nutracêuticos -, energia, cosméticos, higiene pessoal - incluindo os mais sofisticados, com fins terapêuticos, chamados de cosmecêuticos -, indústria farmacêutica, incluindo os fitoterápicos, bionegócio, agronegócio, etc. (LASMAR e SANTOS, 2007).

\footnotetext{
4 Conhecimento que indica um uso para o patrimônio genético: barbatimão é cicatrizante, copaíba é antiinflamatório... (Lei da Biodiversidade, MMA, 2015).

5 Eficiência Smithiana (A. Smith): agentes com livre atuação chegariam ao crescimento, a partir de um processo endógeno de acumulação e investimento, dispensando a ação do Estado para esse efeito (Sachs, 2002).
} 
Segundo o Plano de Desenvolvimento Preliminar - PDP ${ }^{6}$ (SEPLAN, 2013) do APL em estudo, existem quatro cadeias produtivas: fornecimento de matéria prima; extração de óleo bruto, refinamento de óleos vegetais ${ }^{7}$ e indústria de produtos fitoterápicos ${ }^{8}$ e fitocosméticos. A atuação das empresas neste contexto se relaciona ao esforço de cada uma em melhorar suas atividades, administrar e ampliar seu capital, porém, na maioria das vezes desconsideram o meio natural. Para as empresas, isso gera uma força que possibilita ao cluster alcançar níveis mais altos de crescimento, melhorando a produção em escala, essencial para a alavancagem.

No entanto, do ponto de vista da responsabilidade socioambiental é necessário identificar os impactos a partir dos insumos de uso comum e estabelecer mecanismos de inovação para não comprometer a conservação. Segundo Miranda et al (2001), a biodiversidade da região amazônica somente poderá ser utilizada de forma sistematizada por meio de uma proposta transparente de uso econômico das plantas preocupando-se com a manutenção da cobertura vegetal.

Como alternativa, é de suma importância considerar esse parâmetro para espécies que tem sido submetidas a exploração extrativistas. A preocupação da preservação, faz com que haja um compromisso de vinculação entre ciência e a produção, importante para a expansão de modelos e de novas tecnologias. Por exemplo, para a utilização de fontes de matéria prima, fazse necessário favorecer o uso direto por populações amazônicas, associadas à produção e comercialização de produtos regionais (MIRANDA et al, 2001).

\subsection{O MODELO DE ARRANJO PRODUTIVO LOCAL - APL}

Os estudos acerca dos arranjos produtivos locais remontam a um desdobramento do trabalho do economista inglês Alfred Marshall de 1842-1924 sobre os distritos industriais na

\footnotetext{
6 Trata-se de um plano resultante do trabalho de vários técnicos representantes de instituições governamentais e não-governamentais que compõem um núcleo coordenado por uma instituição do governo estadual, criado com a finalidade de estruturar ações para fortalecer as cadeias produtivas com base no apoio do Governo Federal aos segmentos econômicos promissores do Amazonas. Sua função é explicitar às instituições federais e a toda sociedade, em um único documento, o esforço de reflexão e de articulação local que contemple informações para uma Agenda de Compromissos, a respeito dos desafios dos APLs e suas oportunidades de negócio; das ações que estão sendo implementadas ou que precisam ser desenvolvidas com vistas a transformar essas oportunidades em investimentos; e, dos investimentos que precisam ser fortalecidos para que busquem resultados orientados para o desenvolvimento sustentável das localidades (SEPLAN, 2013).

${ }^{7}$ Dentre os óleos vegetais que tem demanda constante, pode-se mencionar a Copaíba, o Urucum, a Andiroba e o Pau-rosa (SEPLAN, 2013).

${ }^{8}$ Todo medicamento tecnicamente obtido e elaborado, empregando exclusivamente matérias primas vegetais com finalidade profilática, curativa ou diagnóstico, com benefício para o usuário. É caracterizado pelo conhecimento da eficácia e riscos de seu uso, assim como pela reprodutibilidade e constância de sua qualidade; é o produto final acabado, embalado e rotulado. Não podem estar incluídas substâncias de outras origens, não sendo considerado produto fitoterápico quaisquer substâncias ativas, ainda que de origem vegetal, isoladas ou associações com extratos vegetais e substâncias ativas. Também são chamados de fitomedicamentos. Nos EUA prevalece a expressão herbal medicines e na União Europeia herbal medicines products (SEPLAN, 2013).
} 


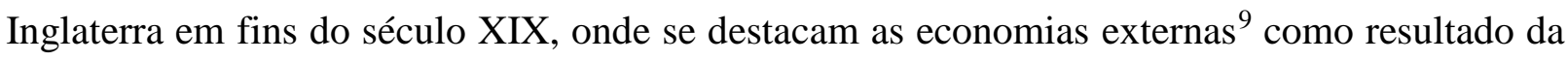
especialização setorial e concentração espacial, conforme defende Schmitz (1999), que utilizou este conceito para definir atividades detentoras de alcance limitado, por envolver apenas ganhos e perdas decorrentes da facilidade de acesso a insumos especializados, mão de obra e outros fatores, que aliadas à ação conjunta dos atores leva à eficiência coletiva.

Schmitz (1999) afirma ainda que as ações conjuntas podem ser incidentais ou planejadas. No primeiro caso, os ganhos de eficiência surgem de forma espontânea, ou seja, derivados da própria existência da aglomeração industrial. São as economias externas puras ou marshallianas. No segundo caso, a eficiência coletiva é resultado de ações conjuntas deliberadas dos atores envolvidos no processo produtivo, tanto de empresas no sentido de cooperação como do setor público na implementação de políticas públicas.

Um Arranjo Produtivo Local - APL tem sua origem normalmente ligada a trajetórias históricas a partir de uma base social comum, ou seja, resulta de um processo histórico cultural. Ambientes com maior integração, cooperação e confiança entre os agentes, são mais propícios à sua construção, em um processo de complementariedade (REDESIST $\left.{ }^{10}, 2009\right)$.

De fato, a cooperação dentro dos APLs é considerada tão importante que representa um dos principais fatores que diferenciam teoricamente esse tipo de aglomeração produtiva dos outros. Não se trata de qualquer cooperação, pois o que se dá nesses espaços é diferente do observado na relação cliente/fornecedor dos complexos petroquímicos e automobilísticos ou nas parcerias estratégicas que ocorrem principalmente na área de desenvolvimento de produtos. $\mathrm{O}$ que merece atenção são os diferentes tipos de cooperação, incluindo a produtiva ${ }^{11}$, que significa obtenção de economia de escala, bem como melhoria dos índices de qualidade e produtividade, diminuição de riscos, custos, tempo e dinamização do potencial inovativo.

\footnotetext{
9 Aglomerações de empresas (especialmente pequenas) em dado local geram economias externas que beneficiam todos. Tipos de economias externas: Disponibilidade de oferta de mão-de-obra local especializada; Conexões das empresas com fornecedores e clientes; Conhecimento e informação sobre inovação produzidas e em uso (SCHMITZ, 1999).

10 Rede de pesquisa interdisciplinar, formalizada desde 1997, sediada no Instituto de Economia da Universidade Federal do Rio de Janeiro e que conta com a participação de várias universidades e institutos de pesquisa no Brasil, além de parcerias institucionais da América Latina, África, Europa e Ásia (REDESIST/UFRJ).

${ }^{11}$ Genericamente existem pelo menos dois tipos: $a$ ) a cooperação coordenada por uma instituição representativa de associação coletiva com autonomia decisória; e $b$ ) a cooperação caracterizada pela colaboração feita para solucionar objetivos específicos, limitados e sem autonomia decisória, independentemente da negociação e do objetivo predefinido das partes. Chama-se aqui o primeiro tipo de cooperação de multilateral, o que pode ser exemplificado por um sindicato, uma associação, cooperativa de crédito, consórcio de exportação, centro de tecnologia ou de treinamento de gestão coletiva ou de associações. O segundo tipo chama-se de cooperação bilateral e pode ser exemplificado como relações formais ou informais de troca de conhecimento, compra de tecnologia, joint ventures, desenvolvimento conjunto e relações de longo prazo cliente/fornecedor (REDESIST/UFRJ).
} 
Para a REDESIST (2009), os APLs são aglomerados ${ }^{12}$ de agentes econômicos, políticos e sociais, localizados no mesmo território que apresentam vínculos consistentes de articulação, interação, cooperação e aprendizagem, incluindo, além das empresas associadas, outras instituições públicas e privadas, de capacitação, $\mathrm{P} \& \mathrm{D}$ e engenharia, promoção e financiamento.

O trabalho com os APLs e estratégias em segmentos alvos abre uma perspectiva alternativa ao modelo ZFM, ainda hoje com setores econômicos não vinculados diretamente aos recursos naturais. O Estado deve possuir planos para o desenvolvimento de segmentos promissores, elaborados via processo endógeno, em que são reunidas ações previstas, além daquelas que as organizações já vêm empreendendo (THURY et al, 2010).

Segundo Thury et al (2010), os APLs se constituem instrumento de intervenção governamental de aproveitamento dos recursos naturais mais promissores, que tem como antecedente o Programa Plataformas Tecnológicas, do Ministério de Ciência e Tecnologia MCT (hoje Ministério de Ciência, Tecnologia e Inovação - MCTI, que demanda inicialmente parceria do Banco da Amazônia - BASA, da extinta SEDEC (atual SEPLANCTI) e da FUCAPI, para avançar nos estudos de segmentos econômicos, como uma maneira de incentivar o uso sustentável da biodiversidade, conforme apontou o "Estudo das Potencialidades Regionais" para sustentabilidade e redução das desigualdades regionais.

No estudo editado pela SUFRAMA (2001), que atua no fomento de cadeias produtivas nos estados da Amazônia Ocidental e nas Áreas de Livre Comércio de Macapá-Santana ALCMS, setores prioritários são indicados a partir de um consenso entre pesquisadores, empresários, produtores e o setor público. Assim, os segmentos priorizados inicialmente são: fitoterápicos e fitocosméticos, fruticultura, piscicultura e madeira.

Se inicia então no governo estadual, um processo de implementação da ação na extinta SEDEC que se apresenta como interveniente entre o MCT e a FUCAPI na implantação do programa Plataformas Tecnológicas, o que veio a contribuir com o processo, discutindo-se gargalos importantes no encadeamento produtivo.

Consta no Plano de Desenvolvimento Preliminar do APL (SEPLAN, 2013), que embora esta iniciativa tenha representado uma ação relevante, a ideia de trabalhar em prol do fortalecimento dos segmentos selecionados tomou forma somente em 2002, durante a elaboração do documento intitulado "Subsídios para Política Pública de Biotecnologia para o Estado do Amazonas", dentro do programa Plataformas Tecnológicas, induzindo a um processo

\footnotetext{
12 Aglomerados são caracterizados por concentrações geográficas de empresas inter-relacionadas, fornecedores especializados, prestadores de serviços, empresas em setores correlatos e outras instituições específicas (Universidades, Órgãos de Pesquisa e Extensão, Órgãos de Regulação, Associações Comerciais, ONGs, etc.), que competem mas também cooperam entre si (Porter, 2000).
} 
de envolvimento e negociação entre os participantes do setor produtivo, universidades, centros de pesquisas, Sistema “S”, Embrapa, governo estadual, entre outros.

O Programa Plataformas Tecnológicas seleciona os primeiros APLs visando incentivar o desenvolvimento das potencialidades regionais, atual e potencial, com foco na sustentabilidade e diminuição das desigualdades regionais, obedecendo o seguinte: 1) Levantamento e análise dos APLs de importância atual e/ou potencial para o desenvolvimento socioeconômico e a diminuição das desigualdades regionais; 2) Seleção dos APLs a serem abordados, com apoio dos Comitês de Gestão estaduais; 3) Análise das principais características dos arranjos selecionados, considerando as relações intra e intersetoriais que os definem; 4) Identificação dos principais gargalos tecnológicos e de formação, qualificação e especialização de mão de obra para o setor produtivo; 5) Definição de ações a serem executadas em empresas, instituições de ensino e pesquisa e de prestação de serviços técnicos e tecnológicos; 6) Definição de projetos cooperativos para concretização das ações; 7) Apresentação dos projetos cooperativos às agências de fomento.

A utilização dos APLs, segundo a REDESIST (2009), é diretriz do Governo Federal que, em parceria com estados, objetiva a geração de emprego e renda, via aglomerações que tenham um número significativo de empreendimentos no território e indivíduos que atuam em torno de uma atividade predominante, e que compartilhem formas percebidas de cooperação e algum mecanismo de governança em rede.

Trata-se de uma articulação estreita entre os agentes institucionalizados para estabelecer as parcerias com o fim de distribuir atividades entre as instituições com maior experiência na área enfocada. Desta forma, é feito um acompanhamento integral e continuado de cada ação quanto à gestão de seus recursos, de seus cronogramas, e da manutenção das informações atualizadas. Requer envolvimento direto dos atores das atividades em todas as fases da estratégia, transferindo desta forma aos participantes todas as informações necessárias à condução da atividade, formando, desse modo, agentes multiplicadores.

Especificamente sobre inovação, existem os Sistemas Produtivos e Inovativos Locais SPIL, que são APLs articulados e com vínculos consistentes, resultantes da interação, cooperação e aprendizagem, possibilitando dessa maneira processos inovativos diversos, que geram maior competitividade empresarial e capacitação social. Sistemas Inovativos (SI) são, portanto, APLs similares aos distritos industriais, em que a capacidade inovativa endógena surge mediante combinação das externalidades incidentes com aquelas que surgem como resultado da ação de cooperação entre os agentes locais (CASSIOLATO et al, 2008). 
Representa um instrumento que une planejamento e ação e é, ao mesmo tempo, um processo de envolvimento e negociação entre as três esferas institucionais, quais sejam, Governo (G), Empresas (E) e Academia (A) - GEA (Figura 2), que podem apresentar as denominadas Redes de Conhecimento ${ }^{13}$, as quais permitem captar rico e diverso conjunto de relações entre as instituições acadêmicas e o setor produtivo, onde as atividades não são, necessariamente, restritas à inovação tecnológica (PIMENTA, 2014).

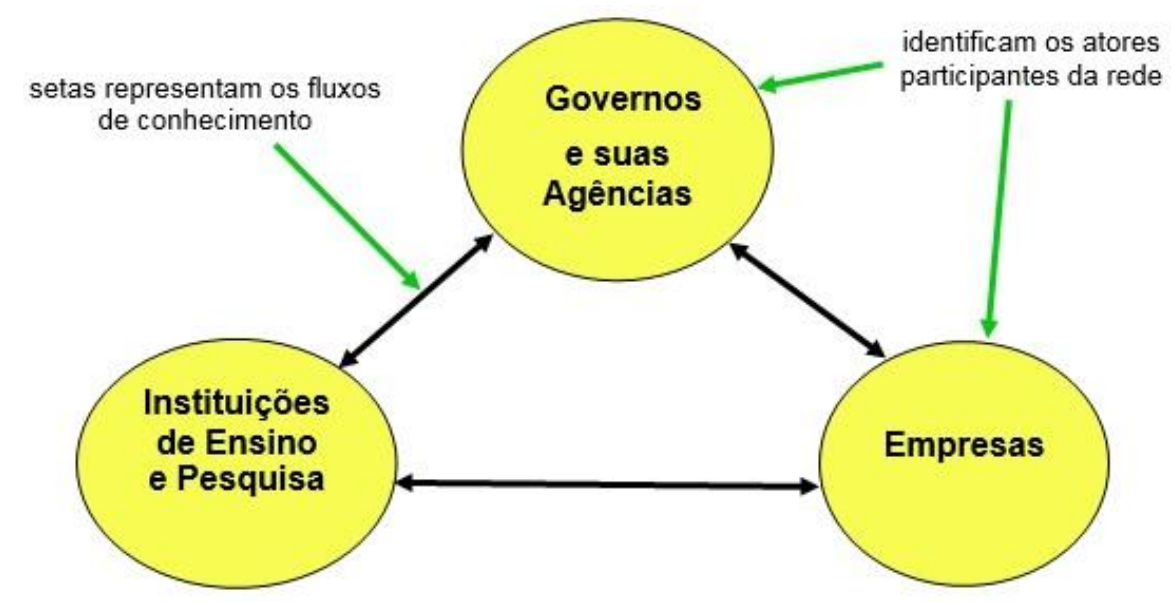

Figura 2 - As Três Esferas Institucionais.

Fonte: Adaptado de Pimenta, 2007.

Conforme Borges (2006), essas três esferas institucionalizadas formam um modelo que une forças em prol de inovação e um novo modo de produção em rede, com relações incertas e uma diversidade de ambientes no estudo da ciência, sendo que tende, inicialmente, a buscar seus pares entre aqueles que atuam na fronteira do conhecimento, principalmente nos países centrais. Já o governo, age com ações diretas do estado para romper o isolacionismo no sistema CT\&I em relação à base econômica.

Foi em 1996 que se discutiu pela primeira vez em uma conferência a questão da interação governo, empresas e academia, a partir do Modelo da Tríplice Hélice ${ }^{14}$ apresentado por Henry Etzkowitz (Universidade Estadual de Nova Yorque, Purchase) e Loet Leydesdorff (Universidade de Amsterdam), que defenderam uma colaboração crescente entre as iniciativas públicas, privadas e universidades, como um novo modo de produção e disseminação do conhecimento. Em 2000, esses cientistas publicaram um artigo incluindo no modelo as redes trilaterais que geram organizações hibridas (BORGES, 2006).

\footnotetext{
${ }^{13}$ Redes de Conhecimento são definidas a partir de fluxos e processos de aprendizagem e de informações e das trocas de conhecimentos que ocorrem entre empresas e instituições, independentemente do fluxo de bens.

${ }^{14}$ Considera múltiplos estágios de geração e disseminação de conhecimento e de interações entre os três agentes (G-E-A), até um ponto em que um ator passa a desempenhar as funções que eram exclusivas de outros autores (Zau e Lasmar, 2015).
} 
Para Pimenta (2014), deve-se recorrer a algumas abordagens para a formação de Redes de Conhecimento, que tem propiciado novas habilitações para solucionar problemas, tais como implementação de inovações; criação de novas empresas; aumento da produtividade e intercâmbios para a transferência de novas tecnologias. Para Zau e Lasmar (2015), isto pode acontecer quando da utilização de alguns recursos como o Modelo Linear ou Modo $1^{15}$, no qual a maioria das instituições de pesquisas acadêmicas e corporativas trabalham de forma isolada e a ciência diverge do interesse da sociedade na produção de conhecimento, ou Modo 2 não Linear, associado a um Sistema de Inovação $^{16}$ (SI) mais interdisciplinar pluralístico e colaborativo, guiado pelo contexto, focado no problema, em que empresas também produzem conhecimento, normalmente visando atender demandas específicas, de forma articulada ou não, com instituições de ensino, $\mathrm{P} \& \mathrm{D}$, buscando a inovação de seus produtos ou, mesmo, a melhoria de seus processos produtivos.

Pimenta (2014) recomenda a formação de Redes de Conhecimento, utilizando a metodologia Hélice Tríplice, para determinar um Sistema Local de Inovação nas áreas de fármacos e cosméticos no Estado do Amazonas. Acrescenta que muitas estratégias estão surgindo em resposta, como, por exemplo, a "Gestão da Inovação Fechada", de Henry Brough, com empresas, mercados e ICTs, e a Rede Europeia "Living Labs". À luz dessas experiências de sucesso, instituições vem trabalhando para implantar Parques Científicos Tecnológicos, com objetivos de adequar sua missão de formação de competências técnicas para atender às necessidades sociais do mercado formando jovens talentos; ampliar a infraestrutura para dar maior consequência socioeconômica; fortalecer a interação com o setor produtivo, pelo intercâmbio de profissionais, compartilhamento de infraestrutura, monitoramento e troca de informações e desenvolvimento conjunto de tecnologias; difundir e socializar conhecimentos via transferência de tecnologias; Estruturar laboratórios multiusuários, incubação das iniciativas dos segmentos institucionais.

No caso do Modelo de APL, o governo brasileiro avançou com a desconcentração espacial na aplicação dos recursos federais, intensificando as parcerias com os estados e atuando com foco no setor produtivo, na perspectiva da constituição e aperfeiçoamento de clusters. Esta abordagem recente apresenta uma perspectiva mais qualitativa e dinâmica das mudanças tecnológicas, enfatizando variáveis como: competitividade sistêmica, inovação,

\footnotetext{
${ }^{15}$ Uma abordagem adotada em tempos recentes para descrever o papel da pesquisa acadêmica na sociedade pós industrial (Zau e Lasmar, 2015).

${ }^{16}$ São organizações - estruturas formais criadas com propósitos específicos - e as instituições - conjuntos de costumes, normas, práticas, regras ou leis comuns, que regulamentam as relações dos indivíduos, grupos e organizações (Zau e Lasmar, 2015).
} 
empreendedorismo, flexibilidade, adaptabilidade, além dos aspectos nas abordagens anteriores como a cooperação e difusão do conhecimento (SANTANA e SANTANA, 2004).

De acordo com a SEPLAN (2013), em um primeiro evento de lançamento e sensibilização, se discutiu a conceituação de fitoterápicos e fitocosméticos segundo a Resolução 17 da ANVISA, bem como as etapas da cadeia produtiva, gargalos tecnológicos e não tecnológicos e ações possíveis com respectivas instituições para resolver.

Foram selecionadas 4 plantas promissoras, priorizadas no APL de Fitoterápicos e 7 plantas como APL de Fitocosméticos. O principal gargalo tecnológico identificado foi o da validação, pois para que um produto possa entrar no mercado ele precisa ser validado e registrado na ANVISA/Ministério da Saúde, e este processo consiste em se realizar diversos ensaios químicos, fisicoquímicos, microbiológicos, analíticos, toxicológicos e farmacológicos, garantindo a segurança e a eficácia do produto em todas as fases do seu prazo de validade, incluindo o armazenamento, a distribuição e o uso (SEPLAN, 2013).

Foram apresentadas as plantas que estariam mais preparadas para ser validadas, sendo as fitoterápicas Muirapuama e Chichuá e a fitocosmética Crajiru. Define-se também as três coordenações de cada área para reunir os especialistas que devem ser envolvidos a fim de validar e elaborar conjuntamente o projeto para cada uma das três plantas selecionadas, os quais seriam encaminhados para a agência financiadora (Quadro 1).

\begin{tabular}{|l|l|l|}
\hline Entidade & Coordenações & Etapas propostas nos projetos \\
\hline INPA & Botânica & $\begin{array}{l}\text { Revisão bibliográfica; inventário botânico; descrição } \\
\text { macroscópica e microscópica; distribuição geográfica. }\end{array}$ \\
\hline INPA & Fitoquímica & $\begin{array}{l}\text { Padronização qualitativa e quantitativa dos princípios ativos } \\
\text { ou marcadores; padronização fisicoquímica e da metodologia } \\
\text { analítica; formação de um banco de padrões; determinação de } \\
\text { contaminantes - principalmente metais pesados. }\end{array}$ \\
\hline UFAM & $\begin{array}{l}\text { Toxicologia, Farmacolo- } \\
\text { gia e Microbiologia }\end{array}$ & $\begin{array}{l}\text { Atividade antidiabética; DL50; toxicidade subaguda e } \\
\text { crônica; exposição a músculo liso; exposição a músculo } \\
\text { estriado; pressão arterial; coração; atividade anti-inflamatória; } \\
\text { ação fertilizante). }\end{array}$ \\
\hline
\end{tabular}

Quadro 1 - Etapas propostas nos projetos para validação das plantas medicinais.

Fonte: Elaborado pelo autor segundo PDP/Seplan, 2013.

A Fundação Nacional de Saúde - FNS encaminha ao governo o "Relatório Final do I Seminário de Inserção de Fitoterápicos na Assistência Farmacêutica do SUS”, que serve de reforço aos trabalhos, manifestando o desejo de todos em ver a proposta de criação de um Polo da Bioindústria do Amazonas transformada em prioridade do governo estadual.

O "I Seminário de APLs e o Desenvolvimento Regional", se caracterizou como um balanço da primeira fase no Amazonas, incluindo painéis e debates sobre o status dos APLs 
prioritários. Segundo diretriz do MDIC durante a Oficina de Orientação à Instalação de Núcleos Estaduais de Apoio a APLs - Região Norte, os APLs devem ser validados junto ao Grupo de Trabalho Permanente - GTP APL.

\subsubsection{Implantação do Núcleo Estadual de APL - NEAPL}

O Núcleo Estadual de Arranjos Produtivos Locais no Amazonas - NEAPL/AM e seu modelo inicial de trabalho (Figura 3), é criado pelo Governo do Estado dentro da SEPLAN por meio do Decreto 26.957, de 3.09.2007, para coordenar, estimular e comprometer as lideranças na elaboração, no acompanhamento e avaliação do PDP - e de promover a articulação institucional e empreendedora de segmentos emergentes, além de analisar as propostas.

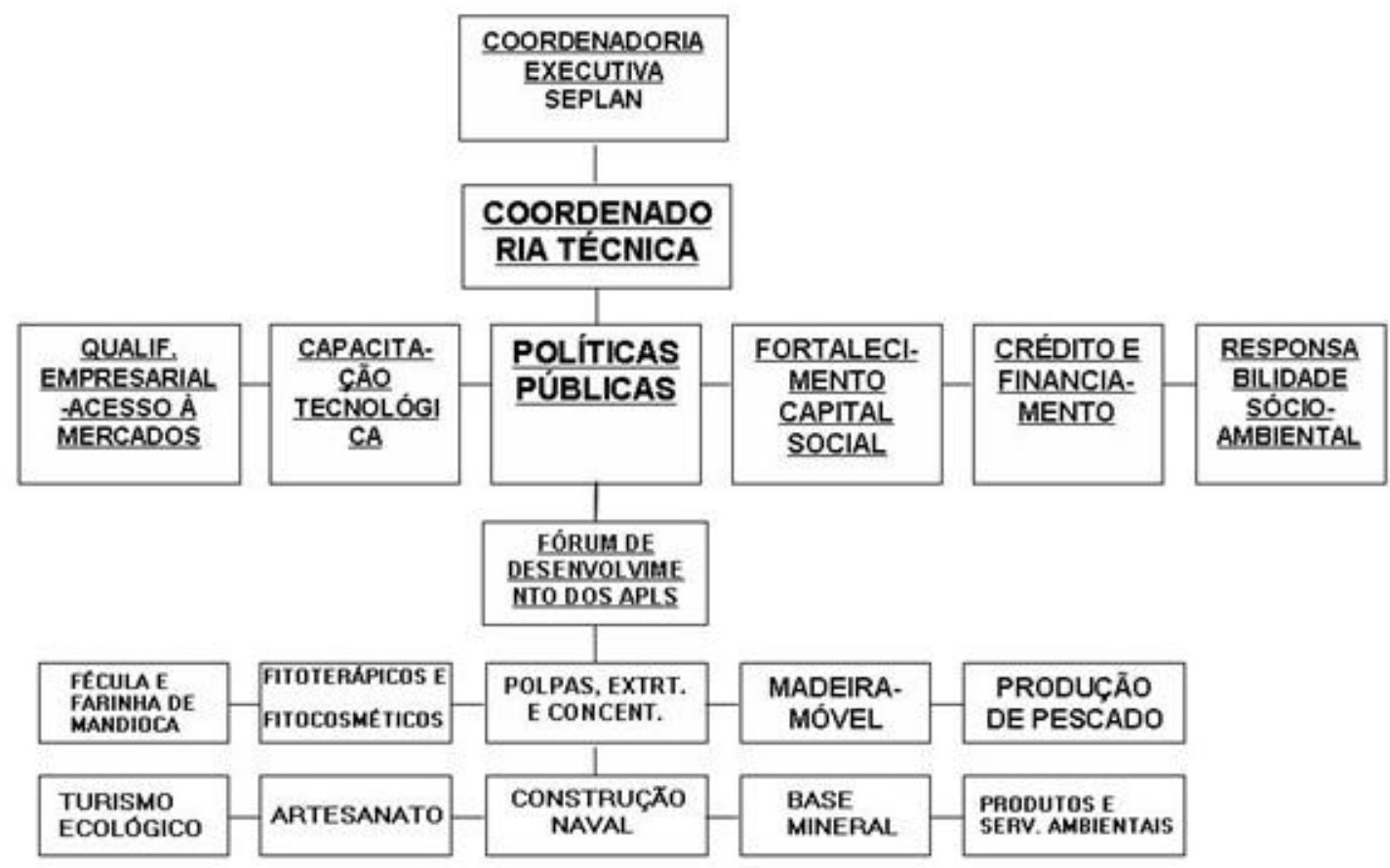

Figura 3 - Estrutura do Núcleo Estadual dos APLs a partir do modelo alvo Fonte: NEAPL/SEPLAN, 2013.

Segundo a SEPLAN (2013), os objetivos do NEAPL são: levantar indicadores socioeconômicos e ambientais e coordenar visitas técnicas; estudar a viabilidade e a potencialidade dos recursos produtivos locais; promover eventos e definir metodologias, atendendo ao perfil do participante e a especificidade de cada comunidade; realizar estudos para o desenvolvimento de instrumentos de integração dos PDPs; e, elaborar, encaminhar e acompanhar a implementação dos PDPs, nos locais fixados.

Para o SEPLAN (2013), os benefícios que o NEAPL pode apresentar são: Desenvolver as vocações, potencialidades e oportunidades locais; ampliar a capacidade competitiva duradoura; melhorar a inserção competitiva e sustentável no mercado; ajudar na inclusão social 
pela via do empreendedorismo; incrementar o protagonismo local - atores ou rede de atores locais liderando processos de mudança.

Os segmentos contemplados inicialmente mais o de mandiocultura, formam os cinco primeiros APLs do Núcleo Estadual do Amazonas, instituído por decreto governamental. Não obstante a identificação do APL em trabalho de mapeamento do Banco da Amazônia, da SUDAM e do GTP-APL/MDIC, aquela que de fato se consubstancia em atuação, com participação do setor público sob a égide dos APLs, foi a do Núcleo Estadual - NEAPL (THURY et al, 2010), conforme se pode visualizar no Quadro 2.

\begin{tabular}{|c|c|c|c|}
\hline $\begin{array}{lr}\text { Projeto } & \text { Iniciativa } \\
\text { Amazônia } & - \\
(2002 \sim 2003) & \text { BASA } \\
\end{array}$ & $\begin{array}{ll}\text { Plano } & \text { Amazônia } \\
\text { Sustentável } & - \text { ADA* } \\
(2003) & \\
\end{array}$ & $\begin{array}{l}\text { GTP/APL }- \\
\text { (2004) }\end{array}$ & $\begin{array}{l}\text { Plano de Desenvolvi- } \\
\text { mento Preliminar - } \\
\text { NEAPL (2007) }\end{array}$ \\
\hline $\begin{array}{l}1 \text { TVs e Monitores } \\
\text { (Manaus) } \\
2 \text { Mandioca (Tefé e } \\
\text { Alvarães) } \\
3 \text { Turismo (Manaus) } \\
4 \text { Pesca Extrativa } \\
\text { (Itacoatiara, Parintins, } \\
\text { Manacapuru, Tapauá) } \\
5 \text { Indústria Material de } \\
\text { Transporte (Manaus) } \\
6 \text { Guaraná (Maués) } \\
7 \text { Ind. de Madeira e } \\
\text { Mobiliário (Manaus e } \\
\text { Itacoatiara). }\end{array}$ & $\begin{array}{l}\text { 1 Avicultura de Postura } \\
2 \text { Mandioca } \\
3 \text { Guaraná } \\
4 \text { Pesca e Piscicultura } \\
5 \text { Fármacos e } \\
\text { Cosméticos } \\
6 \text { Turismo } \\
7 \text { Madeira, móveis e } \\
\text { artefatos } \\
8 \text { Fruticultura } \\
9 \text { Componentes e } \\
\text { produtos do PIM } \\
10 \text { Construção Naval } \\
11 \text { Ind. Reciclagem } \\
12 \text { Produtos não } \\
\text { madeireiros } \\
13 \text { Grãos (milho, arroz e } \\
\text { soja) } \\
14 \text { Dendê (mudas) } \\
15 \text { Pecuária bovina e } \\
\text { bubalina } \\
16 \text { Hortaliças } \\
17 \text { Café } \\
18 \text { Artesanato } \\
19 \text { Minerais para a } \\
\text { construção civil }\end{array}$ & $\begin{array}{l}\text { 1 Apicultura } \\
2 \text { Agricultura } \\
3 \text { Extração de substâncias } \\
\text { tanantes } \\
4 \text { Produtos Aromáticos, } \\
\text { Medicinais e Tóxicos } \\
5 \text { Fabricação de produtos } \\
\text { da mandioca } \\
6 \text { Abacaxi } \\
7 \text { Agricultura / } \\
\text { Mandiocultura } \\
8 \text { Eletroeletrônico } \\
9 \text { Extração Florestal / } \\
\text { Madeireiro } \\
10 \quad \text { Farmacologia } \\
\text { Produtos Fitoterápicos } \\
11 \text { Fruticultura / Castanha } \\
12 \text { Horticultura } \\
13 \text { Madeira e Móveis } \\
14 \text { Turismo } \\
15 \text { Látex/Seringueira } \\
16 \text { Fruticultura / Guaraná } \\
17 \text { Agricultura / Raízes } \\
18 \text { Artesanato Indígena } \\
19 \text { Piscicultura } \\
20 \text { Extração Calcário }\end{array}$ & $\begin{array}{l}1 \text { Fitoterápicos } \\
\text { Fitocosméticos } \\
2 \text { Polpas, Extratos e } \\
\text { Concentrados de Frutas } \\
\text { Regionais } \\
3 \text { Produção de Pescado } \\
4 \text { Madeira, Móveis e } \\
\text { Artefatos } \\
5 \text { Fécula e Farinha de } \\
\text { Mandioca } \\
6 \text { Artesanato } \\
7 \text { Turismo Ecológico e } \\
\text { Rural } \\
8 \text { Base Mineral: Polo } \\
\text { Cerâmico-Oleiro } \\
9 \text { Construção Naval } \\
\text { 10 Produtos e Serviços } \\
\text { Ambientais }\end{array}$ \\
\hline
\end{tabular}

Quadro 2 - Mapeamento dos APLS no Amazonas.

Fonte: Elaborado pelo autor segundo 'Políticas para APLs'. EDUFRN. 2010.

A adoção da estratégia dos APLs, exige uma abordagem sistêmica de sensibilização e mobilização do protagonismo local, por meio de reuniões, oficinas, seminários, entre outros, o que possibilita o levantamento das informações acerca de intervenções realizadas e a realizar, como também o conhecimento da situação de segmentos priorizados, quando do lançamento de um programa de Plataformas Tecnológicas, momento em que se avalia a viabilidade da cadeia produtiva com os atores locais, visando fornecer conteúdos para que o governo com os demais agentes, fomentem o desenvolvimento socioeconômico. 


\subsubsection{Elaboração do Plano de Desenvolvimento Preliminar - PDP}

A iniciativa para a elaboração do PDP se dá em reunião do fórum, aonde são encaminhados os assuntos: validação dos municípios; metodologia; licenciamento ambiental; legislação especial; subsídios; programa de crédito; associativismo/cooperativismo; levantamento de mercado; questionário. É acertado que as organizações informem as ações realizadas, fornecendo indicativos de ações, estratégias e parcerias que culminem na implementação de atividades, a partir da alocação de recursos, com o fim de promover a redução das desigualdades regionais e a inclusão social, gerando ocupação e de renda.

Neste processo busca-se identificar diversos aspectos, em especial, gargalos ao aumento da competitividade, a partir de uma concepção de pesquisa para conhecer diferentes fatores intervenientes e conceber processos produtivos exemplares, não se reduzindo apenas a junção de várias áreas do conhecimento, mas, sobretudo, estabelecendo um fluxo de aglutinação dos saberes, definindo como norte a busca pela alavancagem.

Dentro das atividades a desenvolver, encontra-se a implantação do Programa de Arranjos Produtivos Locais - APLs, ação que pode garantir ao estado um planejamento resultante do esforço de reflexão, articulação e convergência de interesses, contemplando em um Plano de Desenvolvimento Preliminar (PDP), informações sobre desafios e oportunidades, resultados, ações e investimentos necessários a cada APL priorizado.

O PDP aprovado é encaminhado à Secretaria Técnica do GTP APL conforme critérios regulamentados em manual. Esta, por seu turno, encaminha o PDP aos órgãos integrantes a fim de se manifestarem quanto ao tipo e forma de apoio que podem prestar aos APLs. Na sequência é realizado um 'Seminário de Apresentação dos Planos de Desenvolvimento', evento em que são feitas as defesas dos planos dos APLs às instituições do GTP APL do MDIC.

Realiza-se periodicamente também uma 'Atividade de Ajuste dos Planos dos APLs', segundo a avaliação feita pelo GTP APL, com os seguintes objetivos/atividades: ajustar e proceder às correções nos PDPs; priorizar projeto(s)/ação(ões), do grupo das "em andamento" e/ou "previstas"; confirmar o(s) município(s) polo(s) a ser contemplado(s); definir o coordenador e equipe para cada APL; alinhar as ações comuns aos PDPs; indicar nomes e listas para o cadastramento das entidades de classe e ONGs.

\subsubsection{O APL de Fitoterápicos (ou Fármacos) e Fitocosméticos}

De acordo com o Instituto Brasileiro de Geografia e Estatística (2014), a região Amazônica, além da sua vasta extensão territorial, possui enorme riqueza em sua 
biodiversidade, com uma variedade de recursos naturais amplamente utilizados na economia. Herculano (2013), salienta que recursos florestais direcionados à indústria de perfumaria e cosméticos, por exemplo, seria uma opção econômica viável, diante da excepcional riqueza vegetal que a Floresta Amazônica possui.

Acrescenta o autor quanto à utilização para fins econômicos de produção de insumos, que ativos da biodiversidade vegetal amazônica são passíveis de serem utilizados na produção comercial de cosméticos por parte de empresas localizadas em Manaus, no restante do Brasil e no exterior e possuem grande relevância econômica devido ao apelo da marca Amazônia. Existe grande incidência para as indústrias que utilizam plantas medicinais e cosméticos, nos altos rios, em especial na calha dos rios Juruá, Purus, Madeira e Solimões (Figura 4).

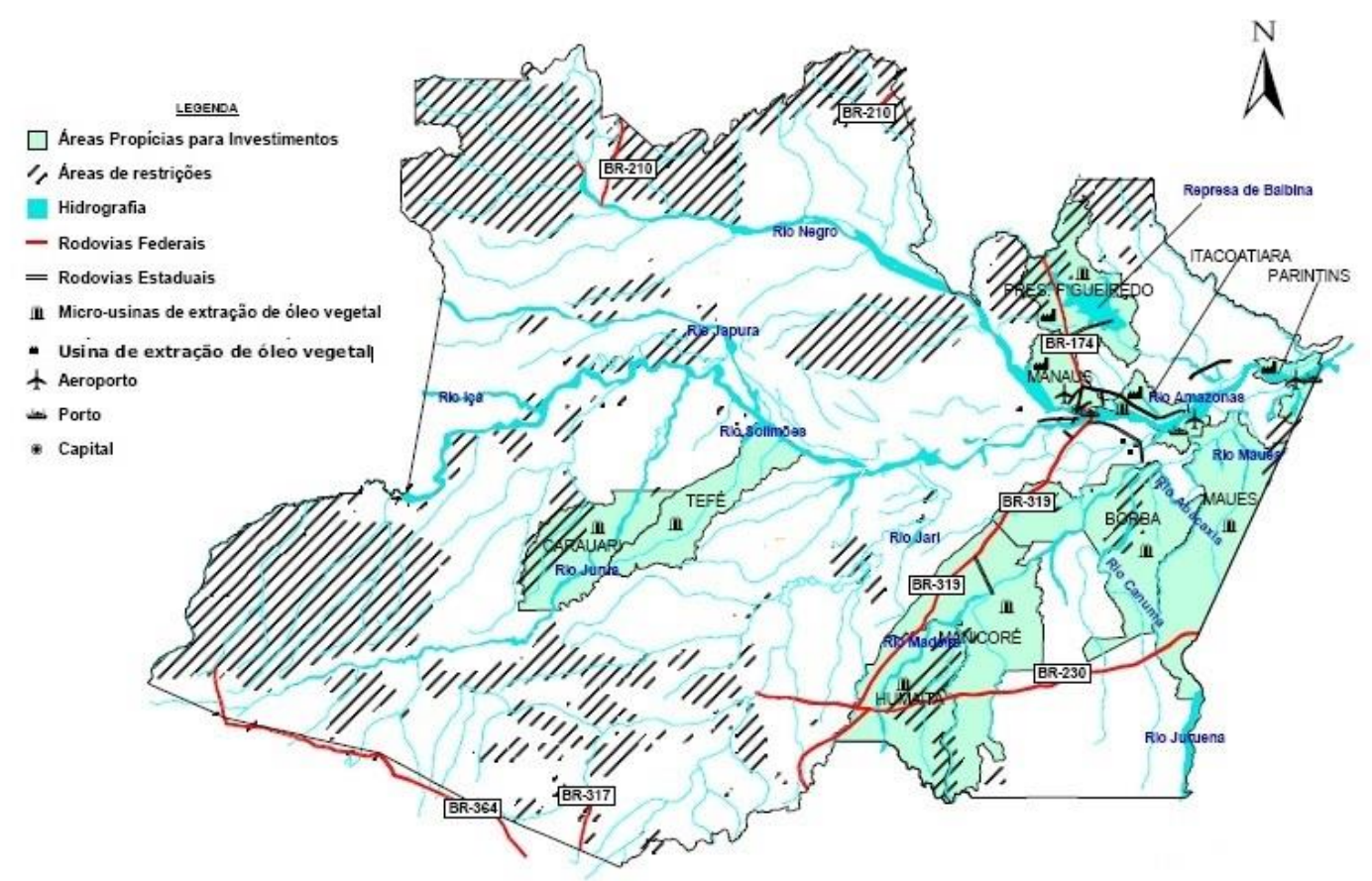

Figura 4 - Áreas Propícias para Investimentos em Fitoterápicos e Fitocosméticos. Fonte: SEPLAN, 2013.

A indústria de bioprodutos busca a matéria prima vegetal como insumo e a biodiversidade amazônica pode ser uma rica fonte para tal fim. O potencial de produção local relaciona óleos vegetais e essenciais, corantes e adoçantes naturais, além de insumos de castanha, açaí, copaíba, entre outros. Segundo Folhadela et al (2015), o Brasil ocupa o terceiro lugar no mercado consumidor global de produtos de $\mathrm{HPPC}^{17}$, atrás da China e EUA, registrando US\$289,5 bi e o latino americano um faturamento total de US\$ 43 bi em 2011. Trata-se de um mercado em ascensão, com crescimento e participação média da ordem de

\footnotetext{
${ }^{17}$ HPPC: higiene pessoal, perfumaria e cosméticos.
} 
$22,3 \%$ e de $10 \%$, respectivamente, tornando difícil justificar a existência de um número tão baixo de empresas de HPPC no Pólo Industrial de Manaus.

No início do cluster no estado do Amazonas havia um pequeno número de empresas, mostrando uma característica: ameaças ao lado de oportunidades. Se de um lado, o reduzido número de empresas atuantes pode indicar dificuldades existentes, de outro, é possível vislumbrar espaço para surgir novos empreendedores, caso as barreiras sejam removidas.

Clusters localizados fora da região testam práticas diferenciadas, estabelecendo contratos de parceria com pequenos produtores. Nesses contratos se prevê o fornecimento de sementes selecionadas, tecnologia de plantio, cultivo, coleta e secagem e a garantia da compra da produção. Este modelo pode servir de referência para experiências na região, considerando as prováveis adaptações que terão que ser realizadas (SEPLAN, 2013).

No SEPLAN (2013), é informado que as empresas do setor são as que mais empregam, incentivam a qualificação, o empreendedorismo e a inovação tecnológica. Dados do MDIC (2010), revelam que empresas da Amazônia lidam diretamente com mais de 35 países. Dentre os produtos mais vendidos estão o açaí, a castanha do Brasil, a andiroba, a copaíba, entre outros, conhecidas como superfrutas devido as suas propriedades.

Produtos substitutos aos fitoterápicos (ou fármacos ${ }^{18}$ ) devem cumprir as mesmas funções. Os medicamentos da indústria farmacêutica são esses produtos. Porém, empresas do setor têm na indefinição sobre a legislação que normalizará o registro de fitoterápicos junto a ANVISA, o seu maior desafio, pois está em questão a viabilidade da indústria fitoterápica no país. Enquanto não são definidas regras, a comercialização de novos produtos é baseada em protocolos de registro, instrumento não aceitável por algumas empresas. Os fitoterápicos que não foram classificados como tradicionais passaram a ser suplementos nutricionais, deixando de conter indicações terapêuticas ou profiláticas nos rótulos (SEPLAN, 2013).

A OMS estima que 25 mil espécies de plantas são usadas no mundo para a produção de medicamentos, incluindo somente aqueles obtidos por síntese a partir dos produtos naturais, mas também os medicamentos comercializados como fitoterápicos. Estima ainda que $85 \%$ da população mundial, cerca de 4 bilhões de pessoas, utilizam plantas medicinais na cura das enfermidades, especialmente dos países pobres e em desenvolvimento.

\footnotetext{
18 Substâncias isoladas de plantas usadas como medicamentos ou na preparação destes. A rutina e a pilocarpina são exemplos de fitofármacos, também chamados de phytomedicines na Alemanha. Os estudos sobre os mercados de fármacos e fitoterápicos nos anos de 1990, tinham como referencial o mercado nacional, sendo que os primeiros estudos não focavam a diferenciação entre fármacos (sintetizados) e fitofármacos, e os demais centraram-se nos fitoterápicos, independente da origem das planta (SEPLAN, 2013).
} 
Todo o mercado brasileiro de medicamentos e cosméticos movimenta em média U\$25 bilhões/ano, a partir de 2003. O mercado de fitoterápicos contribuiu com U\$340 milhões. Se estima que existam hoje, cerca de 120 produtos originários de plantas de uso indígena que estão em estudo clínico. A maior parte dos medicamentos obtidos de plantas é comercializada em grande escala na União Europeia, países asiáticos e nos EUA (SEPLAN, 2013).

Segundo o SEPLAN (2013), inúmeras espécies abundantes na biodiversidade estão no centro da atenção do poderoso mercado mundial de fármacos e fitoterápicos, estimado em U\$22 bilhões, sendo que o Brasil movimenta mais de US\$1 bilhão/ano com aplicação em antibióticos, analgésicos, remédios para aids e câncer.

Muitas empresas brasileiras estão entrando neste disputado mercado que cresce a cada ano, como a Natura e a Aché. Porém, das plantas da Amazônia, também se produzem fitofármacos, substância medicamentosa extraída de plantas. No Amazonas, o segmento, embora incipiente, evolui com negociação de relativamente pouca diversidade de matéria prima, mas com representatividade significativa no mercado mundial (SEPLAN, 2013).

Estimativas da SEPLAN (2013), demonstram que o estado do Amazonas tem todas as condições de participar do mercado de fitoterápicos e fitocosméticos, gerando novos postos de trabalho e um aumento significativo na arrecadação dos impostos estaduais diretos e indiretos. Seu Produto Interno Bruto - PIB é o $16^{\circ}$. maior do Brasil, com destaque para a área industrial e de produtos do extrativismo, sendo que a área de Eletroeletrônicos, Petróleo e Gás e Duas Rodas lideram o ranking. O Amazonas e o Pará, que possuem economia mais desenvolvida, são alvo para o fomento da produção de óleos esseciais, por exemplo.

\subsection{DESENVOLVIMENTO SOCIOECONÔMICO X SUSTENTABILIDADE}

A Comissão Mundial sobre Meio Ambiente e o Desenvolvimento - CMMAD (1991) das Nações Unidas, entende por desenvolvimento o progresso humano em todas as áreas, que deve ser possível a todas as nações. Segundo a CMMAD, houve uma ampliação desse conceito a partir da importância da crítica ambiental e as diversas dimensões da definição de sustentabilidade; da busca por justiça social nas sociedades urbanas pós-modernas; dos movimentos sociais e políticas de empoderamento; do desenvolvimento humano; do ressurgimento ampliado da ética: a ética do convívio entre espécies.

Foi a partir da Conferência em Estocolmo, que se passou a discutir mais o uso racional dos recursos naturais, originando a conceituação de desenvolvimento sustentável, em especial quando acrescidas as contribuições de Strong, quanto aos pilares do ecodesenvolvimento, 
dentro da sustentabilidade social, econômica, ecológica e geográfica, e, a de $\operatorname{Sachs}^{19}$ em 1985, de que precisamos de capacidade de sustentação (XIMENES et al, 2008).

A visão de Sachs (2002) remete ao entendimento do termo sustentabilidade, que surgiu primeiramente vinculado à questão ambiental a partir da preocupação com a preservação ambiental. Sequencialmente, o mesmo termo aparece vinculado aos sistemas humanos e seus diferentes modos de desenvolvimento, agregando além da perspectiva ambiental e entre outras, a social, econômica, cultural e a perspectiva espacial geográfica.

Segundo Ximenes et al (2008), vários autores enfatizam que este conceito foi questionado por não definir quais as necessidades do presente nem quais as do futuro, mas, o Relatório de Brundtland focou sua discussão para a atenção do cenário internacional em se encontrar novas formas de desenvolvimento, sem redução e degradação dos recursos naturais e danos ao ambiente. E mais, definiu três princípios básicos a serem cumpridos: desenvolvimento econômico, proteção ambiental e equidade social.

Segundo Thomé (2010), as políticas ambientais, cujos princípios estão pautados na precaução e prevenção de atividades que causem degradação, devem estar alicerçadas por uma avaliação estratégica dos desafios naturais, por meio da análise sistemática dos impactos advindos da empreendoria humana, considerando-se a interação e a somatória dos efeitos ocasionados num certo território, com o objetivo de promover o desenvolvimento sustentável.

Para Sachs (2002), o desenvolvimento socioeconômico necessita de um padrão de vida dentro dos limites impostos pela natureza, ou seja, deve-se viver dentro da capacidade do meio ambiente, sem desperdício e poluição dos recursos naturais e do ambiente. Defende que no conceito está implícito uma preocupação com a igualdade social entre pessoas de uma mesma geração e pessoas de uma geração e de outra, aonde uma não deve destruir os recursos, impedindo a outra de usar. Para ser consistente e sustentável, deve elevar as oportunidades e a viabilidade e competitividade da economia local, aumentando a renda e a riqueza, ao mesmo tempo em que assegura a conservação da natureza.

Assim, o desenvolvimento local/regional como um processo endógeno registrado em unidades territoriais e grupos humanos capaz de promover o dinamismo econômico local e a qualidade de vida, pode representar singular transformação nas bases econômicas e organização

19 Ignacy Sachs (Varsóvia, 1927) é um economista polonês, naturalizado francês. Também é referido como ecossocioeconomista, por sua concepção de desenvolvimento como uma combinação de crescimento econômico, aumento igualitário do bem-estar social e preservação ambiental. O termo ecossocioeconomia foi cunhado por Karl William Kapp, economista de origem alemã e um dos mais brilhantes inspiradores da ecologia política nos anos 1970. Há mais de trinta anos Sachs lançou alguns dos fundamentos do debate contemporâneo sobre a necessidade de um novo paradigma de desenvolvimento, baseado na convergência entre economia, ecologia, antropologia cultural e ciência política. Suas idéias são hoje mais claramente compreendidas, no cenário das mudanças climáticas e da crise social e política mundial. 
social em nível local, resultando em mobilização social, exploração de capacidades e potencialidades específicas (BUARQUE, 2002).

A ideia de 'envolver populações locais' remete à reflexões sobre a natureza do espaço geográfico e a necessidade de saberes empíricos, base do estudo de Milton Santos, que buscou a reconstrução intelectual do mundo nas experiências com foco no lugar, considerando 'espaço como instância social'; 'categoria de formação socioespacial'; 'geografia como filosofia das técnicas'; 'o presente como dialética de uma ordem global e local; 'força da solidariedade organizacional destruindo solidariedade orgânica', tornando o espaço mais racional; 'normas como meio de homogeneização técnica e organizacional'; face material da globalização refletida na expansão técnico-científico-informacional (ELIAS, 2002).

De acordo com Lasmar e Santos (2007), com o surgimento de um novo paradigma tecno-econômico para exploração de recursos naturais, houve o interesse do referido tema na agenda pública nas últimas décadas. Neste contexto, fica evidente a importância de se estimular mecanismos de desenvolvimento regional sustentável, com uma estratégia de efetiva participação de unidades de produção local.

Em sua retórica, Sachs (2002) agrega o pensamento de Robert Kuttner que demonstrou ser a eficiência smithiana raramente aliada da eficiência keynesiana, direcionada para a plena utilização do potencial de produção, e da eficiência schumpeteriana relativa à inovação tecnológica. Se for somada a essas três a ecoeficiência, a busca simultânea para uma quarta solicitação de extensiva regulamentação do mercado irá requerer algum tipo de intervenção e planejamento por parte do Estado, fazendo frente a contra-revolução neoliberal com o ressurgimento do mito laissez faire.

O autor citado, salienta que o pensamento de Kuttner é fundamental porque mostra que nem tudo está à venda, ao mesmo tempo em que procura equilíbrio entre mercado, Estado e sociedade civil, considerando as perspectivas corretas para redimensionar economias mistas e reabilitar o planejamento, ferramenta indispensável para promover estratégias de produtividade.

Como um esforço de iniciativa, o SEBRAE/AM (2015) participa com a ação do Encadeamento Produtivo (Figura 5), que é uma estratégia para ampliar a competitividade, a cooperação, a competência tecnológica e a gestão das empresas, por intermédio de relacionamentos cooperativos, de longo prazo e mutuamente atraentes, que se estabelecem entre grandes, médias, pequenas e microempresas de sua cadeia de valor.

Para o SEBRAE/AM (2015) cadeia de valor é uma rede estratégica de empresas que se articula para levar um produto desde a produção primária até o consumidor final. Esta rede se baseia na complementaridade e especialização do trabalho e das funções entre seus integrantes, 
visando criar vantagens competitivas e benefícios para toda a cadeia, gerar maior valor agregado e obter uma distribuição mais equitativa dos custos, benefícios e riscos.

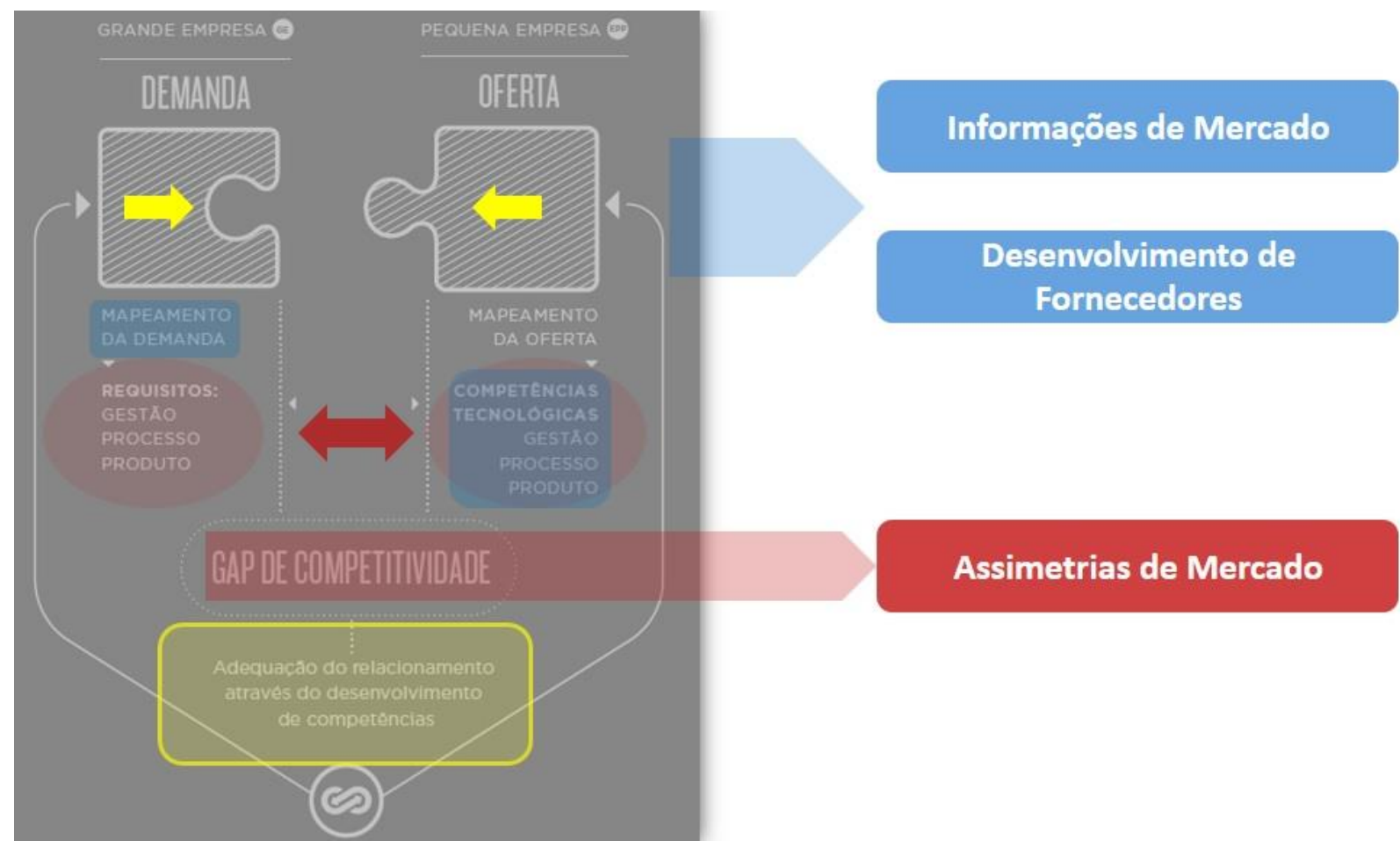

Figura 5 - Encadeamento Produtivo

Fonte: Adaptado de SEBRAE/AM. 2015.

Portanto, nesta linha de pensamento cluster $^{20}$ ou APL é uma cadeia de valor que se encontra em uma mesma localidade. É uma concentração geográfica de empresas estreitamente conectadas, ao longo de uma cadeia de valor ou como uma rede que se estabelece em torno de um comprador/empresa, agroindústria ou supermercado, por exemplo (SEBRAE/AM, 2015).

\subsection{EFICIÊNCIA DO DESEMPENHO}

O termo 'eficiência' significa que os recursos estão a ser usados da melhor forma possível para satisfazer às necessidades e desejos das pessoas. Dito de outra forma, a existência de eficiência é sinônimo de ausência de desperdício. Para Nascimento (2007), do ponto de vista formal - a eficiência somente tem valor se conservar a natureza e produzir equidade social.

Segundo Neely e Adams (2001), a medição do desempenho é um processo utilizado para quantificar a eficiência da empresa, nos processos de negócio ou atividades realizadas por

20 Cluster é uma concentração geográfica e setorial de micro e pequenas empresas, operando com intensa cooperação nas etapas do processo de produção. Esta concentração propicia ganhos de eficiência coletiva ou vantagem competitiva resultante de economias externas e da ação conjunta (SCHMITZ, 1999). 
pessoas. Trata-se de um método que contribui com o processo de tomada de decisão porque permite quantificar a eficiência e eficácia de ações passadas, facilitando o uso da informação.

Para Galdámez (2009) apud Gerolamo, o processo de gestão de desempenho do APL:

[...] pode caracterizar-se a partir do planejamento de estratégias de desenvolvimento sustentável para a região. É operacionalizado com a implantação de métodos de melhoria e mudança (ações cooperadas) que promovem o desempenho do arranjo produtivo e o capital social. Demanda uma infraestrutura de cooperação e um processo de avaliação de desempenho para tomar as decisões e promover o processo de inovação contínua.

Conforme Suzigan et al (2002) ocorreram muitos avanços na medição de desempenho (Quadro 3) nos aspectos econômicos, apesar de existir uma lacuna na área de gestão da produção por processos. Os conceitos, métodos, técnicas e práticas de gestão da produção podem contribuir com o processo de desenvolvimento das MPEs inseridas em APLs.

\begin{tabular}{|l|l|}
\hline \multicolumn{1}{|c|}{ MÉTODO } & \multicolumn{1}{c|}{ FONTE } \\
\hline - SMART - "Performance Pyramid" & - Cross e Linch (1990); McNair et alli (1990) \\
\hline $\begin{array}{l}\text { - Sistema de Medição de Desempenho para } \\
\text { Competição Baseada no Tempo }\end{array}$ & - Azzone et alli (1991) \\
\hline - Sistema de Feedback de Gestão do Desempenho & - Graddy (1991) \\
\hline - Balanced Scorecard (BSC) & $\begin{array}{l}\text { - Kaplan e Norton (1992); Kaplan e Norton } \\
\text { (1993); Kaplan (1994); Kaplan e Norton (1996) }\end{array}$ \\
\hline - Modelo para Medição do Valor Adicionado & - Barker (1993) \\
\hline - Estruturas de Indicadores de Gestão & - Muscat e Fleury (1993) \\
\hline - Sete Critérios do Desempenho & - Sink e Tutle (1993) \\
\hline - Medição do Progresso da TQM & - Cupello (1994) \\
\hline - Matriz do Objetivo de Desempenho & - Das (1994) \\
\hline - Desempenho Quantum & - Hronec (1994) \\
\hline - Performance Measurement Questionnaire (PMQ) & - McMann e Nanni (1994); Rummler e Brache \\
\hline - Modelo de Medição de Desempenho para & - Kasul e Motwani (1995) \\
\hline Manufatura Classe Mundial & - Lee et alli (1995) \\
\hline - Sistema de Avaliação do Desempenho do Negócio & - Rose (1995) \\
\hline - Modelo de Medição de Desempenho & - Bemowski (1996), Best (1997) e Brown (1997) \\
\hline - Prêmio da Qualidade "Malcolm Baldrige” & - De Toni e Tonchia (1996) \\
\hline - Medição de Desempenho para Gestão por Processos & - Bititci et alli (1997) \\
\hline - Sistema de Medição de Desempenho - SMD Integrado & - Daniels e Burns (1997) \\
\hline - Sistema de Medição de Desempenho Proativo & - Ghalayini et alli (1997) \\
\hline - SMD Integrado e Dinâmico & - Nickols (1997) \\
\hline - Accountability Scorecard & - Slater et alli (1997) \\
\hline - Strategic Scorecard &
\end{tabular}

Quadro 3 - Avanços na medição de desempenho.

Fonte: Martins, 1999.

Utilizando essa hipótese como base, foi construído um Sistema de Medição do Desempenho - SMD, para APLs, a partir das pesquisas realizadas nos APLs de Ibitinga Indústria de Bordados de Cama, Mesa e Banho; e Jaú - Indústria de Calçado Feminino, 
vislumbrando as perspectivas de gestão de desempenho e os respectivos indicadores de avaliação de desempenho (GALDÁMEZ, 2009).

Diversos autores do Brasil, como, por exemplo, Galdámez, Suzigan, Lastres, Cassiolato, Oliveira, Caporali, Volker, entre outros, utilizam-se de métodos de aplicação de variáveis para demonstrar análises relacionadas à medição de desempenho da eficiência, eficácia e efetividade dos APLs para a melhoria dos produtos e serviços e a inovação das Microempresas e Empresas de Pequeno Porte (EPP $)^{21}$, as quais podem ter seu faturamento comprometido pela ausência do uso de métodos e ferramentas de melhoria contínua. Na literatura de SMDs, o porte da empresa é tratado de uma forma genérica, percebendo-se que ainda é reduzido o número de publicações que descrevem, especificamente, as características dos SMDs para MPEs.

Galdámez (2009) destaca que os principais elementos determinantes para o uso do SMD são: a capacidade da empresa em satisfazer os clientes (resultados), a capacitação das pessoas, os recursos financeiros disponíveis, a forma de coletar as informações, os métodos de processamento de informações e meios utilizados para distribuir e armazenar as informações.

Caporali e Volker (2004) relacionam a eficiência com a produtividade por ser um dos eixos responsáveis pela gestão da empresa e onde se trata da necessidade de investimento em formação gerencial na busca da ampliação do capital humano, formação profissional, empreendedorismo e aprimoramento de processos produtivos visando alcançar maior eficiência. Não é somente obter o máximo de eficiência "fazendo certo as coisas", mas, atingir o máximo de eficácia "fazendo as coisas certas" (Figura 6). É necessário ir além do conceito básico de output/input e entender os fatores determinantes da melhoria da produtividade.

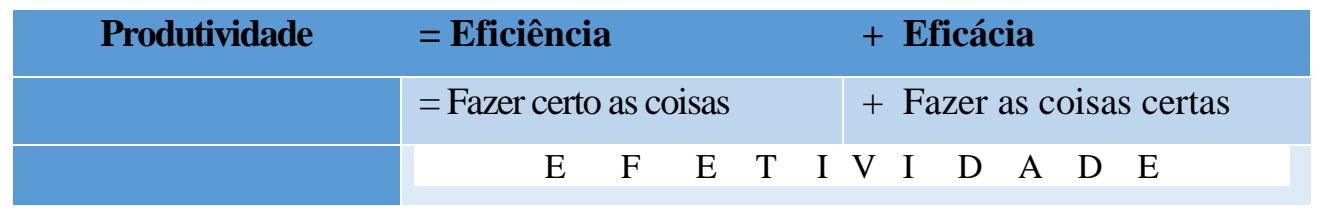

Figura 6 - Produtividade e Eficiência.

Fonte: elaborado pelo autor.

\footnotetext{
${ }^{21}$ A microempresa é conceituada na Lei n. 7.256/84, pautada pela Lei n. 9.841, de 05/10/1999 que determina normas não só para a microempresa mais também para as de pequeno porte, atendendo ao disposto que se encontra nos artigos 170 e 179 da CF, que diz "é assegurado às MPEs tratamento jurídico diferenciado e simplificado nos campos administrativo, tributário, previdenciário, trabalhista, creditício e de desenvolvimento empresarial, em conformidade com o que dispõe esta Lei e a Lei no 9.317, de 5.07.1996, e alterações posteriores". A Lei Geral, também conhecida como Estatuto Nacional da MPEs, foi criada pela Lei Complementar Federal 123/2006 para regulamentar tratamento favorecido, simplificado e diferenciado a esse segmento de negócios, conforme disposto na $\mathrm{CF}$, definindo-se que Microempresas são empreendimentos com receita bruta anual igual ou inferior a $\mathrm{R} \$$ $360.000,00$ e EPP com receita bruta anual superior a $\mathrm{R} \$ 360.000,00$ e igual ou inferior a $\mathrm{R} \$ 3,6$ milhões. No caso da EPP, em 2016 passou de $\mathrm{R}$ 3,6 milhões para $\mathrm{R}$ \$ 4,8 milhões/ano e também mudança nas tabelas do SIMPLES, com a inserção de alíquotas progressivas (Portal da Lei Geral, 2017).
} 
Segundo os autores citados, a produção em MPEs vem aumentando nos países desenvolvidos, servindo até como indicador para o desenvolvimento. Paradoxalmente, nos países em desenvolvimento predominam grandes negócios, se excluindo muitas vezes as MPEs das políticas oficiais, embora constituam maior contingente de produtores e serem responsáveis por uma considerável parcela da produção de produtos básicos.

Para o Instituto de Assessoria para o Desenvolvimento Humano - IADH (2010), é possível tomar como parâmetro mais próximo alguns exemplos de sucesso no Brasil (Quadro 4), com destaque para o APL de Biotecnologia da Região Metropolitana de Belo Horizonte, um conjunto de empresas do setor de biotecnologia e ciências da vida, que tem atuado em regime de cooperação com o objetivo de ganhos coletivos e externalidades positivas para empresas.

Para Meyer-Stamer e Harmes-Liedtke (2001) a avaliação de desempenho é um instrumento importante para o processo de aprendizagem em termos de gestão de desempenho dos aglomerados. O fator mais importante do sucesso destes APLs (Quadro 4), foi a organização dos stakeholders $^{22}$ em prol do fortalecimento e êxito na empreendedoria do APL, chegando a um estágio avançado de relação empresarial e autogestão, o que deve ser propiciado pelo estado, que por seu turno, deve exercer um papel crucial nesse sentido, sendo o articulador dessas estratégias, especialmente na formação de mão de obra qualificada (IADH, 2010).

\begin{tabular}{|c|c|c|c|c|c|}
\hline & TIC & EMHO & Metalmecânico & BIOTEC & Apicultura \\
\hline Estrutura & \begin{tabular}{|l|}
200 peq. empresas; \\
4 grandes exterior; \\
CESAR; segmentos \\
especializados; Ele- \\
vada Cooperação. \\
\end{tabular} & \begin{tabular}{|lr}
69 empresas; & $80 \%$ \\
pequenas; & $20 \%$ \\
médias; & Baixa \\
Cooperação. & \\
\end{tabular} & $\begin{array}{l}\text { CSN; Empresas ânco- } \\
\text { ras automotriz + 471 } \\
\text { metalm.+ } 79 \text { plástico; } \\
\text { Coop. específica: for- } \\
\text { necedores e âncoras. } \\
\end{array}$ & $\begin{array}{l}57 \text { EPPs; Segmen- } \\
\text { tos especializados; } \\
\text { Média cooperação }\end{array}$ & $\begin{array}{l}1.600 \text { cooperados + } \\
\text { Unidade Institu- } \\
\text { cional + CENTAP; } \\
\text { Cooperação vertical }\end{array}$ \\
\hline $\mathrm{CoO}$ & $\begin{array}{l}\text { OSCIP; } \\
\text { Gestácleo de do Porto } \\
\text { Digital (NGPD); }\end{array}$ & $\begin{array}{l}\text { Fundação Municipal; } \\
\text { FIPASE (CEDINA + } \\
3 \text { Incubadoras + } \\
\text { Núcleo Tecnológico) }\end{array}$ & $\begin{array}{l}\text { Sindicato; METAL- } \\
\text { SUL + SEBRAE + } \\
\text { FIRJAN. }\end{array}$ & \begin{tabular}{|l|} 
AMBIOTEC: \\
empresas; Assoc. \\
Civil direito priva- \\
do + FIEMG + SE- \\
BRAE+ SEDEMG. \\
\end{tabular} & $\begin{array}{l}\text { CASA APIS; } 9 \\
\text { Cooperativa }+ \\
\text { Central; Conselho } \\
\text { Consultivo; CS. de } \\
\text { Apicultura. } \\
\end{array}$ \\
\hline $\begin{array}{l}\text { Política } \\
\text { Pública }\end{array}$ & $\begin{array}{l}\text { Governo PE; Porto } \\
\text { Digital; Revitaliza- } \\
\text { ção urbana; Econo- } \\
\text { mia Criativa; PRO } \\
\text { APL com BID. } \\
\end{array}$ & $\begin{array}{ll}\text { Prefeitura; } & \text { Governo } \\
\text { SP; Parque } & \text { Tecnoló- } \\
\text { gico USP. }\end{array}$ & $\begin{array}{l}\text { SEDEIS/RJ; Proble- } \\
\text { mas de infraestrutura } \\
\text { e Meio Ambiente. }\end{array}$ & $\begin{array}{l}\text { Governo MG tem } \\
\text { Superintendência } \\
\text { de APL e Programa } \\
\text { com o BID. }\end{array}$ & $\begin{array}{l}\text { SEDEC/PI; FBB; } \\
\text { SEBRAE; } \\
\text { CODEVASF. }\end{array}$ \\
\hline
\end{tabular}

Quadro 4 - Casos recentes de sucesso de APLs no Brasil.

Fonte: Instituto de Assessoria para o Desenvolvimento Humano - IADH, 2010.

Entretanto, nos APLs do Brasil, a avaliação ou medição de desempenho (Figura 7) não é uma prática comum na gestão da produção por processo, o que compromete a eficiência das ações e uso de fontes financeiras e humanas, entre outros. Para uma avaliação da eficiência é

\footnotetext{
${ }^{22}$ Stakeholders: Podem ser representados por uma pessoa ou grupo de pessoas que tem um relacionamento formal com o negócio. A capacidade é definida como a combinação de pessoas, práticas, tecnologias e a infraestrutura da empresa, aspectos que coletivamente criam valor para seus stakeholders a partir das atividades integradas dos processos gerenciais e operacionais, alinhadas com a estratégia da empresa (NEELY; ADAMS, 2001).
} 
preciso contar com a existência de variáveis determinantes como, por exemplo: concentração de unidades e cadeias produtivas; localidade e território; capital humano e social; capacidade tecnológica e empreendedora; disponibilidade de assistência técnica (GALDÁMEZ, 2009).

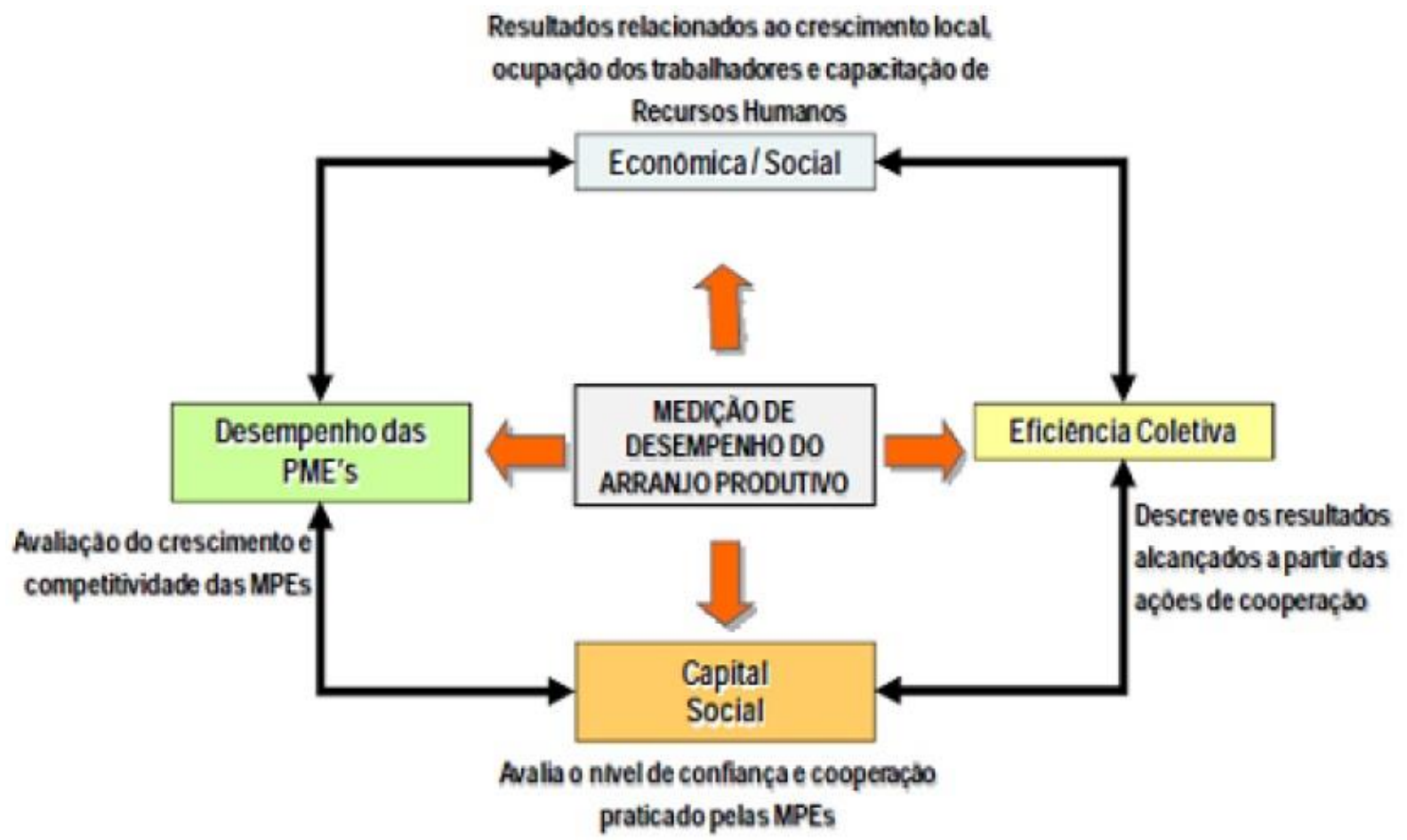

Figura 7 - Perspectiva de gestão da medição de desempenho para APLs. Fonte: Galdámez, 2009.

Em Maringá, Paraná, se desenvolveu um trabalho a partir do projeto de cooperação no APL, cujo objetivo foi implantar ações de melhoria nas empresas, por meio de indicadores de desempenho (Figura 8) construídos a partir do diagnóstico nas áreas de produção e qualidade nas empresas.

Entre os principais resultados que o projeto promoveu destaca-se a introdução de práticas de gestão do desempenho empresarial nas MPEs, estimulando a cooperação, a inovação contínua nos processos de manufatura e qualidade dos produtos e processos. Estes indicadores somados aos de outros casos citados anteriormente (Ibitinga e Jaú) constituem referência para o estudo do APL de Fitoterápicos e Fitocosméticos, proporcionando uma investigação com variáveis adequadas à sua realidade (Quadro 5).

Quando se conhece o nível de desempenho é possível perceber quão longe se está dos objetivos da sustentabilidade e o que precisa ser revisto para que a sua trajetória seja revertida em prol da conservação, da mesma forma em que é possível entender melhor os resultados da avaliação da maturidade da cadeia produtiva. A gestão da medição do desempenho da 
eficiência se torna uma forma do APL saber onde está, como evoluir, contribuir nos ganhos sociais e mitigar os impactos ambientais (CAPORALI e VOLKER, 2004).

\begin{tabular}{|c|c|c|c|c|c|c|}
\hline $\begin{array}{c}\text { Perspectiva } \\
\text { de } \\
\text { desempenho }\end{array}$ & $\begin{array}{c}\text { Indicadores } \\
\text { de } \\
\text { desempenho }\end{array}$ & Objetivo & Método & Unidade & $\begin{array}{l}\text { Frequiência } \\
\text { da medida }\end{array}$ & Resp. \\
\hline \multirow{4}{*}{$\begin{array}{l}\text { Desempenho } \\
\text { das MPEs }\end{array}$} & Produtividade & $\begin{array}{l}\text { Aumentar a } \\
\text { quantidade } \\
\text { de produtos } \\
\text { produzidos }\end{array}$ & $\begin{array}{c}\text { Valor } \\
\text { adicionado / } \\
\text { N. de pessoas } \\
\text { ocupadas }\end{array}$ & $\mathrm{R} \$ / \mathrm{PO}$ & Semestral & \multirow{9}{*}{ 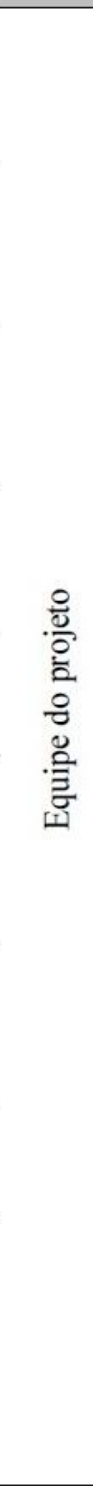 } \\
\hline & $\begin{array}{l}\text { Prazo de } \\
\text { Entrega }\end{array}$ & $\begin{array}{l}\text { Reduzir } \\
\text { prazos de } \\
\text { entrega dos } \\
\text { produtos }\end{array}$ & $\begin{array}{l}\text { Tempo de } \\
\text { entrega do } \\
\text { pedido }\end{array}$ & Dias & Semestral & \\
\hline & Terceirização & $\begin{array}{l}\text { Melhorar a } \\
\text { produtividad } \\
\text { e das facções }\end{array}$ & $\begin{array}{c}\text { Refugo / } \\
\text { Produção e } \\
\text { Quantidade / } \\
\text { Tempo } \\
\end{array}$ & $\%$ & Semestral & \\
\hline & Qualidade & $\begin{array}{l}\text { Melhorar a } \\
\text { qualidade } \\
\text { dos produtos }\end{array}$ & $\begin{array}{c}\text { Peças } \\
\text { defeituosas / } \\
\text { quantidade } \\
\text { produzida }\end{array}$ & $\%$ & Semestral & \\
\hline \multirow[t]{3}{*}{$\begin{array}{l}\text { Economia } \\
\text { Local }\end{array}$} & $\begin{array}{l}\text { Pessoas } \\
\text { Ocupadas }\end{array}$ & $\begin{array}{c}\text { Incentivar a } \\
\text { geração de } \\
\text { emprego }\end{array}$ & $\begin{array}{c}\text { Pessoas } \\
\text { ocupadas nas } \\
\text { MPEs }\end{array}$ & Pessoas & Semestral & \\
\hline & $\begin{array}{c}\text { Pessoas } \\
\text { Qualificadas }\end{array}$ & $\begin{array}{c}\text { Melhorar } \\
\text { liabilidades e } \\
\text { competência } \\
\text { s da mão-de- } \\
\text { obra local } \\
\end{array}$ & $\begin{array}{l}\text { Pessoas que } \\
\text { concluíram os } \\
\text { cursos de } \\
\text { capacitação }\end{array}$ & Pessoas & Semestral & \\
\hline & Rotatividade & $\begin{array}{c}\text { Reduzir a } \\
\text { rotatividade } \\
\text { de } \\
\text { funcionários } \\
\end{array}$ & In put / out put & Pessoas & Semestral & \\
\hline $\begin{array}{l}\text { Eficiência } \\
\text { Coletiva }\end{array}$ & $\begin{array}{l}\text { Cooperação } \\
\text { Empresarial }\end{array}$ & $\begin{array}{l}\text { Aumentar a } \\
\text { cooperação } \\
\text { empresarial }\end{array}$ & $\begin{array}{c}\text { Projeto de } \\
\text { Cooperação } \\
\text { Empresarial }\end{array}$ & Empresa & Semestral & \\
\hline $\begin{array}{l}\text { Capital } \\
\text { Social }\end{array}$ & $\begin{array}{l}\text { Porcentagem } \\
\text { de einpresas } \\
\text { envolvidas em } \\
\text { ações de } \\
\text { cooperação }\end{array}$ & $\begin{array}{l}\text { Aumentar o } \\
\text { número de } \\
\text { participantes } \\
\text { (MPEs) }\end{array}$ & $\begin{array}{l}\text { Número de } \\
\text { MPEs que } \\
\text { participaul de } \\
\text { ações } \\
\text { coletivas/ } \\
\text { Total de MPEs } \\
\text { do Projeto }\end{array}$ & $\%$ & Semestral & \\
\hline
\end{tabular}

Figura 8 - Alguns indicadores de desempenho para APLs.

Fonte: Oliveira et al (2010).

De acordo com Almeida e Almeida (2004), o motivo que leva as organizações a utilizarem as ferramentas de medição de desempenho é o fato que, por meio delas, conseguem: identificar as atividades que agregam valor ao produto e/ou serviços desenvolvidos pela empresa; realizar comparações de desempenho com seus concorrentes; e, rever estratégias organizacionais para curto, médio e longo prazo na obtenção de resultados. 
O modelo de APLs requer mecanismos que viabilizem o desempenho contínuo das MPEs nos processos de gestão empresarial. Para promover a melhoria contínua é fundamental que as empresas tomem decisões baseados em dados que reflitam o desempenho empresarial (Medição de Desempenho) e promova o desempenho do aglomerado (OLIVEIRA et al, 2010).

\begin{tabular}{|c|c|c|}
\hline Variável & Descrição & Fonte \\
\hline $\begin{array}{l}\text { Nível de } \\
\text { enquadramento }\end{array}$ & $\begin{array}{l}\text { Refere-se a classificação das MPEs segundo seu nível de } \\
\text { faturamento. }\end{array}$ & Portal da Lei Geral \\
\hline $\begin{array}{l}\text { Conhecimento do } \\
\text { APL }\end{array}$ & $\begin{array}{l}\text { Identifica como a empresa conheceu o modelo de APL e } \\
\text { a formação de redes de conhecimento nas áreas de } \\
\text { fármacos e cosméticos no Estado do Amazonas. }\end{array}$ & $\begin{array}{l}\text { Caporali e Volker, 2004; } \\
\text { Pimenta, 2014. }\end{array}$ \\
\hline $\begin{array}{l}\text { Instrumento de } \\
\text { inserção no Apl }\end{array}$ & $\begin{array}{l}\text { Identificação de programas, ações, entre outros, capazes } \\
\text { de arregimentar empresas para o Apl. }\end{array}$ & Caporali e Volker, 2004 \\
\hline $\begin{array}{l}\text { Inserção nos } \\
\text { mercados interno } \\
\text { e externo }\end{array}$ & $\begin{array}{l}\text { Capacidade produtiva e mercadológica da empresa, a fim } \\
\text { de garantir condições de concorrência sustentáveis nos } \\
\text { mercados interno e externo. }\end{array}$ & $\begin{array}{l}\text { Suzigan et al., 2002; } \\
\text { Mendonça, } 2008\end{array}$ \\
\hline $\begin{array}{l}\text { Desenvolvimento } \\
\text { Tecnológico }\end{array}$ & $\begin{array}{l}\text { Compreende a participação das unidades de produção, } \\
\text { por meio de atitudes práticas conjuntas, em relação à } \\
\text { força de trabalho no aumento do emprego e da renda. }\end{array}$ & $\begin{array}{l}\text { Suzigan } \text { et al., } 2002 ; \\
\text { Lasmar 2005; Mendonça, } \\
2008\end{array}$ \\
\hline $\begin{array}{l}\text { Especialização } \\
\text { Produtiva }\end{array}$ & $\begin{array}{l}\text { Envolve além da produção de bens, conhecimento, tácito } \\
\text { ou explicito, que as pessoas/empresas de um território } \\
\text { possuem em torno de uma atividade econômica principal. }\end{array}$ & $\begin{array}{l}\text { Zacarelli, 1995; Suzigan } e t \\
\text { al., 2003; Herculano, } 2014 .\end{array}$ \\
\hline $\begin{array}{ll}\text { Estrutura } & \text { de } \\
\text { Governança } & \end{array}$ & $\begin{array}{l}\text { Identifica os canais (pessoas físicas ou organizações) } \\
\text { capazes de coordenar e promover ações de negócios e } \\
\text { processos decisórios entre os atores de um APL. }\end{array}$ & $\begin{array}{l}\text { Takeda et al., 2008; } \\
\text { Mendonça, } 2008\end{array}$ \\
\hline $\begin{array}{l}\text { Cooperação } \\
\text { Empresarial }\end{array}$ & $\begin{array}{l}\text { Caracteriza as relações entre as empresas frente ao } \\
\text { ambiente instável de negociação ao qual estão imersas. }\end{array}$ & $\begin{array}{c}\text { Lasmar 2005; Oliveira et } \\
\text { al., } 2010\end{array}$ \\
\hline $\begin{array}{l}\text { Eficiência } \\
\text { Coletiva }\end{array}$ & $\begin{array}{l}\text { Analisa a capacidade de redução de gastos associados às } \\
\text { transações entre agentes econômicos. }\end{array}$ & Oliveira et al., 2010 \\
\hline $\begin{array}{l}\text { Capacidade de } \\
\text { competição }\end{array}$ & $\begin{array}{l}\text { Compreende os elementos responsáveis pela melhoria da } \\
\text { competitividade individual e coletiva. }\end{array}$ & $\begin{array}{l}\text { Suzigan } \text { et al., 2002; Porter, } \\
\text { 2000; Mendonça, } 2008\end{array}$ \\
\hline $\begin{array}{l}\text { Desempenho das } \\
\text { MPEs }\end{array}$ & $\begin{array}{l}\text { Exame do aumento da quantidade e qualidade dos } \\
\text { produtos produzidos/produtividade e qualidade. }\end{array}$ & Oliveira et al., 2010 \\
\hline $\begin{array}{l}\text { Trajetória } \\
\text { Evolutiva }\end{array}$ & $\begin{array}{l}\text { Trata da evolução da produção, qualidade e de } \\
\text { comercialização. }\end{array}$ & $\begin{array}{c}\text { Suzigan } \text { et al., 2002; } \\
\text { Siqueira, 2003, Mendonça, } \\
2008 \\
\end{array}$ \\
\hline $\begin{array}{ll}\text { Tecnologia } & \text { da } \\
\text { Informação } & \\
\end{array}$ & $\begin{array}{l}\text { Representa o grau de absorção e utilização da tecnologia } \\
\text { da informação na empresa. }\end{array}$ & $\begin{array}{l}\text { Oliveira et al., 2010; } \\
\quad \text { Pimenta, } 2014 .\end{array}$ \\
\hline Capital Social & $\begin{array}{l}\text { Representa o aumento do número de participantes } \\
\text { envolvidos em ações de cooperação. }\end{array}$ & $\begin{array}{l}\text { Oliveira et al., 2010; } \\
\quad \text { Pimenta, } 2014 .\end{array}$ \\
\hline Tecido Social & $\begin{array}{l}\text { O capital social é determinante para o desenvolvimento } \\
\text { socioeconômico, através da confiança mútua, participa- } \\
\text { ção, organização e cooperação entre os atores sociais. }\end{array}$ & $\begin{array}{l}\text { Suzigan } \text { et al., 2002; } \\
\text { Siqueira, 2003, Mendonça, } \\
2008\end{array}$ \\
\hline $\begin{array}{l}\text { Capacitação } \\
\text { Tecnológica }\end{array}$ & $\begin{array}{l}\text { Refere-se ao processo de criação, absorção e difusão de } \\
\text { novos conhecimentos traduzidos em produtos. }\end{array}$ & $\begin{array}{l}\text { Crocco et al., 2003; Lasmar } \\
\text { 2005; Mendonça, } 2008\end{array}$ \\
\hline
\end{tabular}

Quadro 5 - Variáveis de eficiência do desempenho selecionadas.

Fonte: elaborado pelo autor.

Gerolamo et al (2008) enfatiza que o processo de gestão de desempenho do APL pode caracterizar-se a partir do planejamento de estratégias de desenvolvimento sustentável para a região. É operacionalizado com a implantação de métodos de melhoria e mudança (ações cooperadas) que promovem o desempenho do APL e o capital social. Demanda uma infra- 
estrutura de cooperação e um processo de avaliação de desempenho para tomar as decisões e promover o processo de melhoria e inovação contínua do APL (Figura 9).

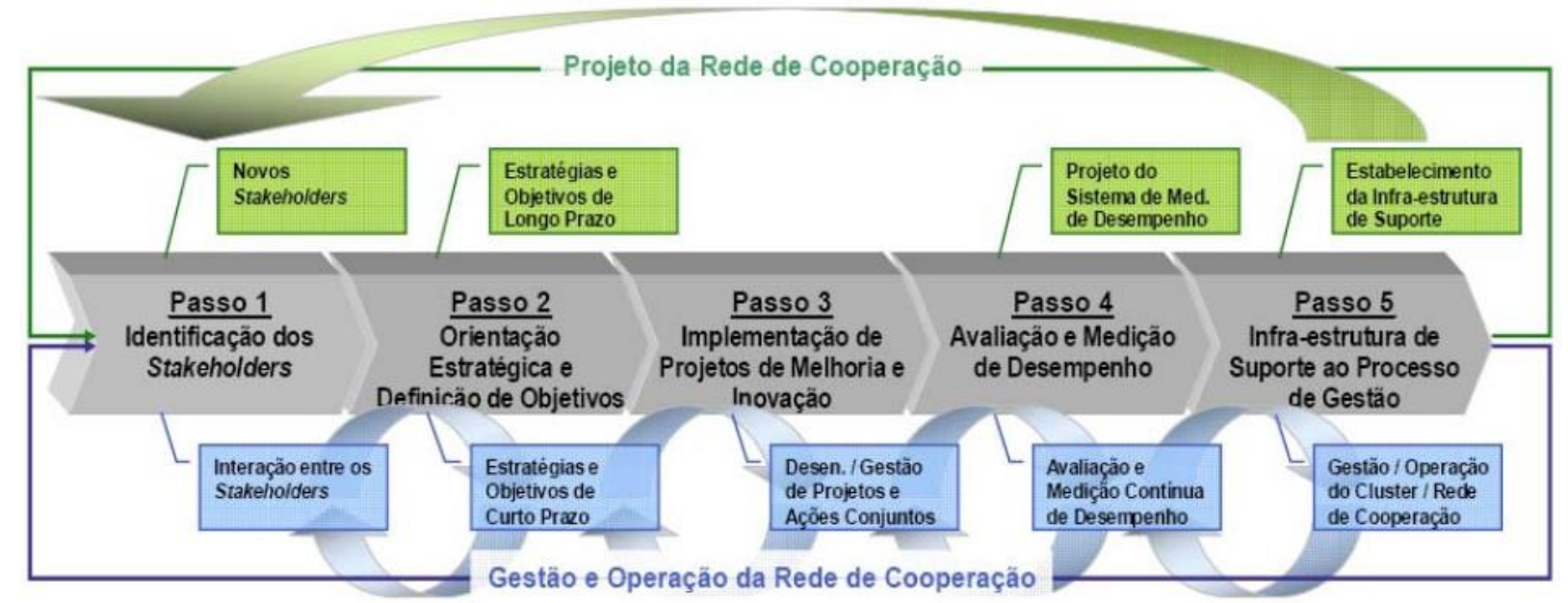

Figura 9 - Gestão do desempenho de APLs e a Rede de Cooperação.

Fonte: Gerolamo et al (2008).

Para Kotler e Keller (2006), a Matriz SWOT (FOFA em português), que serve para identificar forças (strengths), oportunidades (opportunities), fraquezas (weaknesses) e ameaças (threats), é uma técnica em que se pode analisar fatores internos e externos das empresas, bem como transformar oportunidades em grande potencial. Daychouw (2007), afirma que é uma ferramenta para analisar detalhes ocultos, vitais para definir decisões estratégicas (Figura 10).

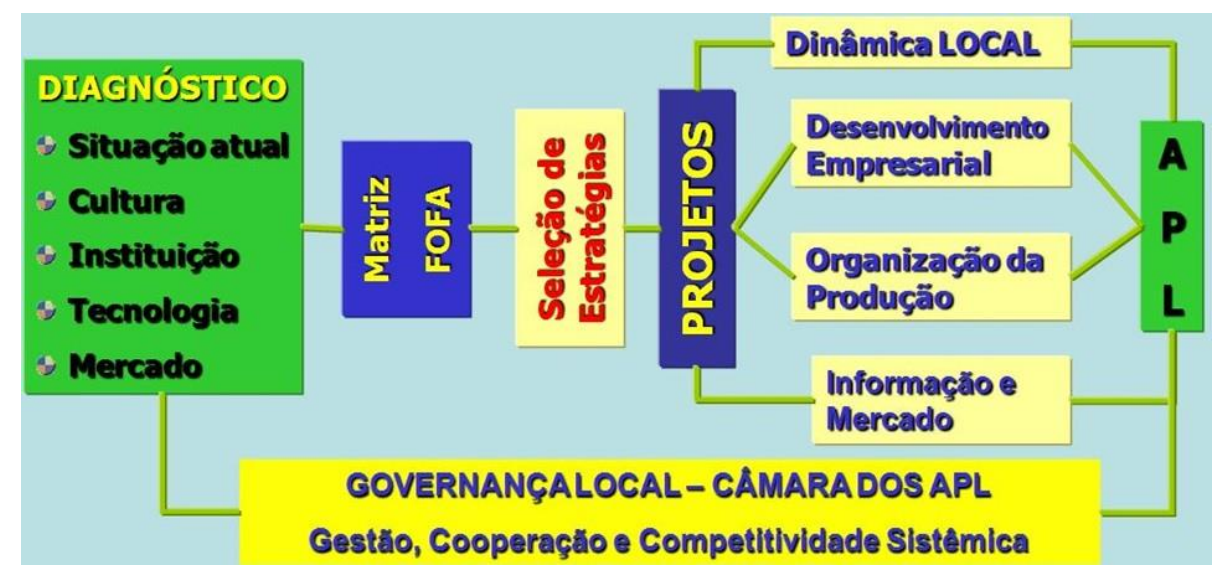

Figura 10 - Perspectiva de gestão de APLs com a SWOT (FOFA) Fonte: Adaptado de Antônio Oliveira, UFPA (2009).

\subsection{ESTRATÉGIA}

Para Caporali e Volker (2004), quando se considera as cadeias produtivas, a organização da produção e, consequentemente seu crescimento, aparece como estratégia ${ }^{23}$ a

${ }^{23}$ É a criação de uma posição singular e valiosa, envolvendo um conjunto diferente de ações. É o padrão ou plano que integra metas, políticas e sequência de ações em um todo coerente (Porter, 2000). 
observar porque se volta à produtividade, se relacionando ao fundamento da eficiência do desempenho, como produção total ${ }^{24}$, custos totais (soma dos fixos mais variáveis) e marginais, recursos humanos, logística, tecnologia e finanças, enfim, tudo o que pode gerar uma relação de aproveitamento que viabilize o crescimento de mercado.

Nesse contexto, fica evidente a importância de se estimular mecanismos de desenvolvimento com uma estratégia de efetiva participação de MPEs. Na consolidação desse sistema é fundamental o desenvolvimento de procedimentos tecnológicos adequados à realidade socioeconômica das cadeias produtivas regionais. Se destaca, também, que neste sistema sejam tomados os cuidados necessários para minimizar os impactos ambientais.

Segundo Caporali e Volker (2004), a construção de modelos sólidos e realizáveis, que definam sua estratégia e estabeleçam sua linha de atuação, incluindo planos de redução dos custos e de investimentos em tecnologia, com o objetivo de qualificar e certificar produtos e processos, representam soluções fundamentais para o desenvolvimento sustentável. A sua implementação permite diagnosticar a eficiência do desempenho, especialmente, quando se conhece o nível econômico dos micro e pequenos empreendedores ou produtores.

Com uma estratégia metodológica de intervenção, é possível optar pela visão sistêmica devido à existência de interdependências entre os componentes que participam dos segmentos econômicos. A base conceitual da visão sistêmica utilizada tem em seu conteúdo fundamental os conceitos de sistema, interações e organização do sistema. Com esta aliança, envolvendo instituições parceiras, se consolida e dissemina modelos estratégicos, de modo técnico, com a adoção de metodologias adequadas, para atendimento do mercado demandante regional, nacional e internacional, culminando com o resgate, através da inserção socioeconômica, da dignidade dos produtores e empreendedores (HAMMERSCHMIDT e SANTOS, 2012).

Para tanto, é imprescindível utilizar-se de um 'planejamento estratégico', que segundo Chiavenatto (2008) é um processo gerencial que se refere à formulação de objetivos para a seleção de programas de ação e para sua execução, levando em conta as condições internas e externas à organização e sua evolução esperada. Também considera premissas básicas que a organização deve respeitar para que todo o processo tenha coerência e sustentação.

O planejamento estratégico do APL prevê o futuro da organização, em relação ao longo prazo. De forma genérica, consiste em saber o que deve ser executado e de que maneira. Este é crucial para o sucesso da organização, e a responsabilidade da estratégia se assenta sobretudo nos gestores de topo, dado o nível de decisões que é necessário tomar (Figura 11) .

\footnotetext{
24 Também denominada de produto total, se refere à quantidade total produzida num determinado período de tempo (Matesco et al, 2008).
} 
É vital em todos os tipos de organização como instrumento para o atingir metas, em especial quando o objetivo, no caso de política pública, é concretizar o desenvolvimento sustentável, com geração de emprego e renda, por conseguinte, melhoria da qualidade de vida.

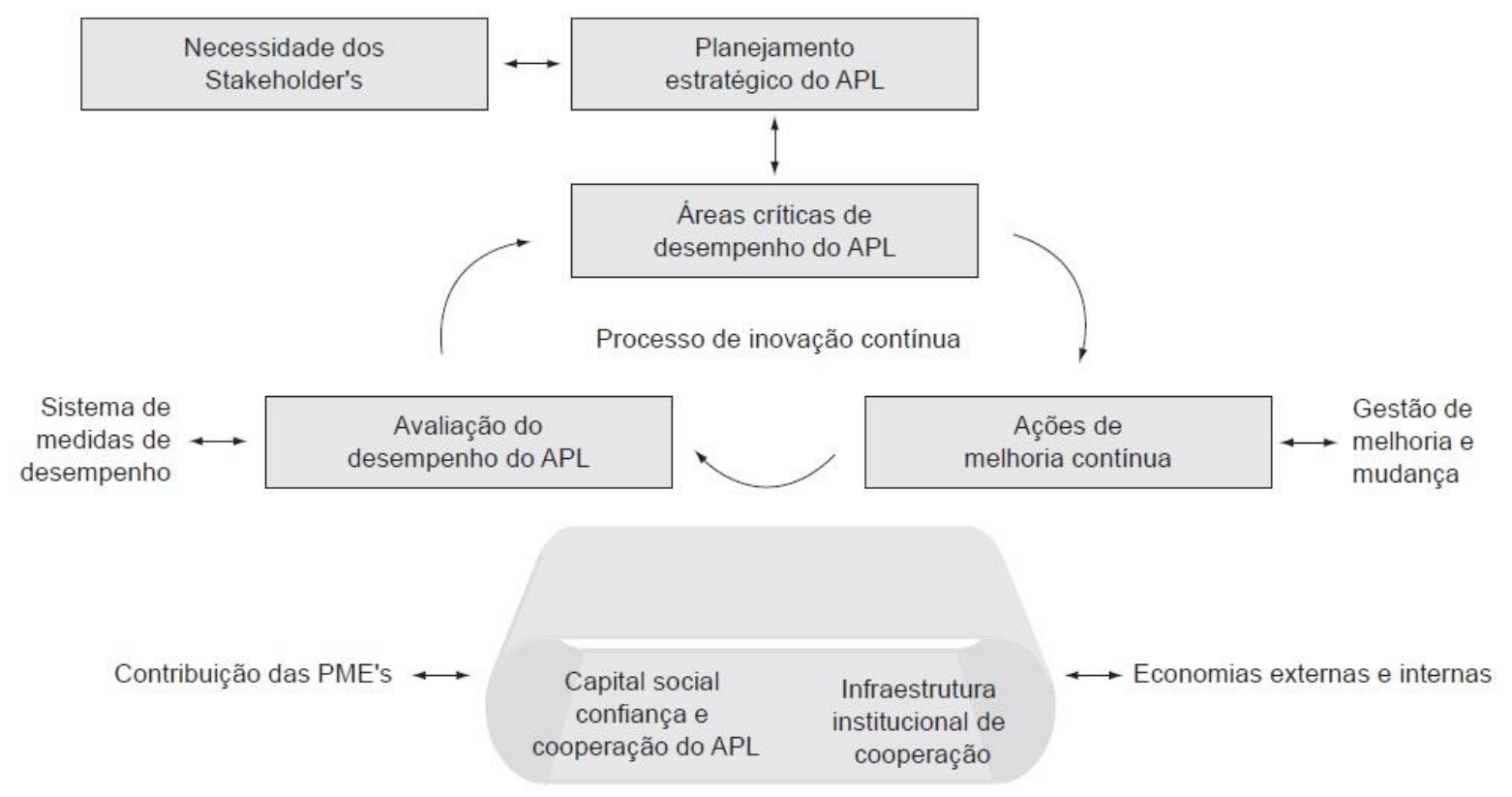

Figura 11 - Modelo de gestão de desempenho para APLs.

Fonte: Galdámez, 2009.

O último planejamento do Estado intitulado "Plano Estratégico de Desenvolvimento do Amazonas 2012-2030" foi desenvolvido na então Secretaria de Planejamento e Desenvolvimento Econômico - SEPLAN (atual SEPLANCTI) e parceiros, com atividades sobre racionalização e coordenação das ações de governo; incremento dos APLs; expansão do mercado de trabalho; descentralização e interiorização do processo de desenvolvimento; viabilização do atendimento, com redução de custos, das políticas públicas e da atenção ao cidadão; e melhoria das condições gerais da administração, de modo a viabilizar, no campo prático e efetivo, os projetos, atividades e ações de Estado para a sociedade.

Como esta tese se volta para o APL de Fitoterápicos e Fitocosméticos não se poderia deixar de fora essa referência até para posterior análise da situação. Para a SEPLAN (2013), neste tema o plano estratégico baseia-se no princípio de desenvolvimento sustentável e foi concebido com a missão de enfrentar desafios econômicos e socioambientais, aliados aos desafios típicos das distâncias, heterogeneidade, dificuldade de logística e custo de transporte.

Um plano deve analisar, com base em diagnóstico, experiências de desenvolvimento vivenciadas até então e volta-se para o futuro, captando as transformações que são manifestadas na região, no país e no mundo, bem como as tendências prováveis, ajustando as trajetórias, compatibilizando-as com a evolução do processo econômico e exigências da sociedade. 
Segundo a SEPLAN (2013), os produtos esperados em seu plano estratégico devem servir para potencializar, economicamente, os recursos naturais; aumentar a produtividade agrícola com novas tecnologias; reestruturar, reconverter e expandir as atividades produtivas, com vista a dois grandes macro objetivos: especial atenção à ZFM e o desenvolvimento do interior; estabelecer uma base educacional capaz de refletir as tendências vocacionais de cada localidade; reestruturar a organização administrativa do Estado, para um serviço de qualidade.

Consta no "Plano Estratégico de Desenvolvimento do Amazonas 2012-2030" uma visão segmentada com vistas ao meio socioeconômico, aonde vislumbra investimento em recursos humanos, capacitando a força de trabalho para as novas exigências do padrão tecnológico necessário às diversificações produtivas enunciadas no plano, sendo esse papel assumido pelo sistema de ensino médio, superior, público e privado.

O resultado esperado é que se tenha uma competitividade sistêmica ${ }^{25}$ obtida pela diversificação e reestruturação produtiva e pela ampliação e diversificação de mercado, estimulando as exportações, tomando como base o crescimento sustentado no trinômio meio ambiente, homem e produção (Figura 12).

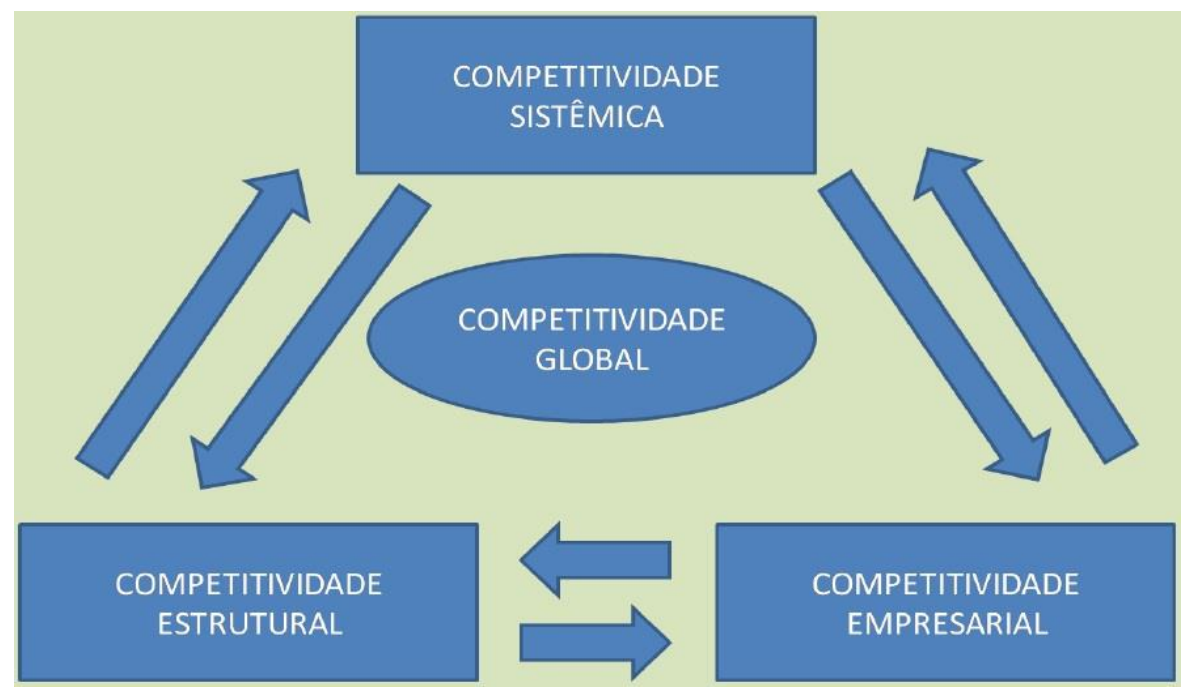

Figura 12: Níveis de competitividade.

Fonte: Souza (2004)

Na questão ambiental propõe um novo relacionamento entre o homem e a natureza, que contempla o uso racional e metódico de seus recursos e, paralelamente a sua conservação, tendo com centro do ambiente o homem e a produção, o seu meio de sustentação.

\footnotetext{
${ }^{25}$ A competitividade sistêmica é caracterizada por políticas diferenciadas para um conjunto de empresas. No nível estrutural são realizadas atividades em conjunto, como fabricação dos produtos, obtenção de crédito e capacitação, valorização do produto e da marca, participação em feiras e eventos, dentre outros fatores. O nível empresarial é onde se realizam atividades na busca de desenvolvimento tecnológico, como cursos de treinamento e formação, criação de novas tecnologias, busca por consultoria tecnológica e atividades neste sentido (Souza, 2004).
} 
Os princípios básicos do plano enfatizam a mediação entre presente e futuro e entre passado e futuro; previsão de possibilidades quando a predição for impossível; capacidade de lidar com surpresas e mediação entre conhecimento e ação. Sua elaboração teórica pauta-se na problematização das ameaças e oportunidades atuais e potenciais e as demandas da sociedade.

Também sugere a definição do conteúdo propositivo, com base na análise de cenários e dos atores, resultados desejados e recursos disponíveis; viabilidades para garantir sua realização com o máximo de eficiência, com ação sobre a realidade concreta e a própria gestão.

O Plano Estratégico de Desenvolvimento do Amazonas 2012-2030 está relacionado com a adaptação da organização a cenários mutáveis, sujeito às incertezas a respeito dos eventos ambientais, ajustando-se à complexidade de um mundo competitivo e suscetível a mudanças. Envolve o Estado como uma totalidade, abarcando todos os seus recursos, no sentido de obter efeitos sinérgicos de todas as capacidades e potencialidades existentes. Suas principais características são: Orientação para resultados e indicadores; Transparência, participação e controle social; Atitude e ambiente empreendedores; Profissionalização da Gestão Pública; Articulação de recursos públicos e privados; Ênfase na regulação, na promoção e na parceria com a sociedade; Planejamento como ferramenta indispensável.

O plano apresenta variáveis para estabelecer indicadores de crescimento e/ou desenvolvimento dos seus produtos e serviços para o Estado do Amazonas, dentre os quais se destacam: produtividade, capacidade, efetividade, qualidade, competitividade. Esses indicadores estão relacionados aos objetivos previstos nos macrocenários.

Meio ambiente e regionalização (Cenário 1): Proceder o macrozoneamento ecológicoeconômico a partir do conhecimento da realidade social e ambiental do Estado com vista a execução de um plano diretor de desenvolvimento sustentável (Figura 13).

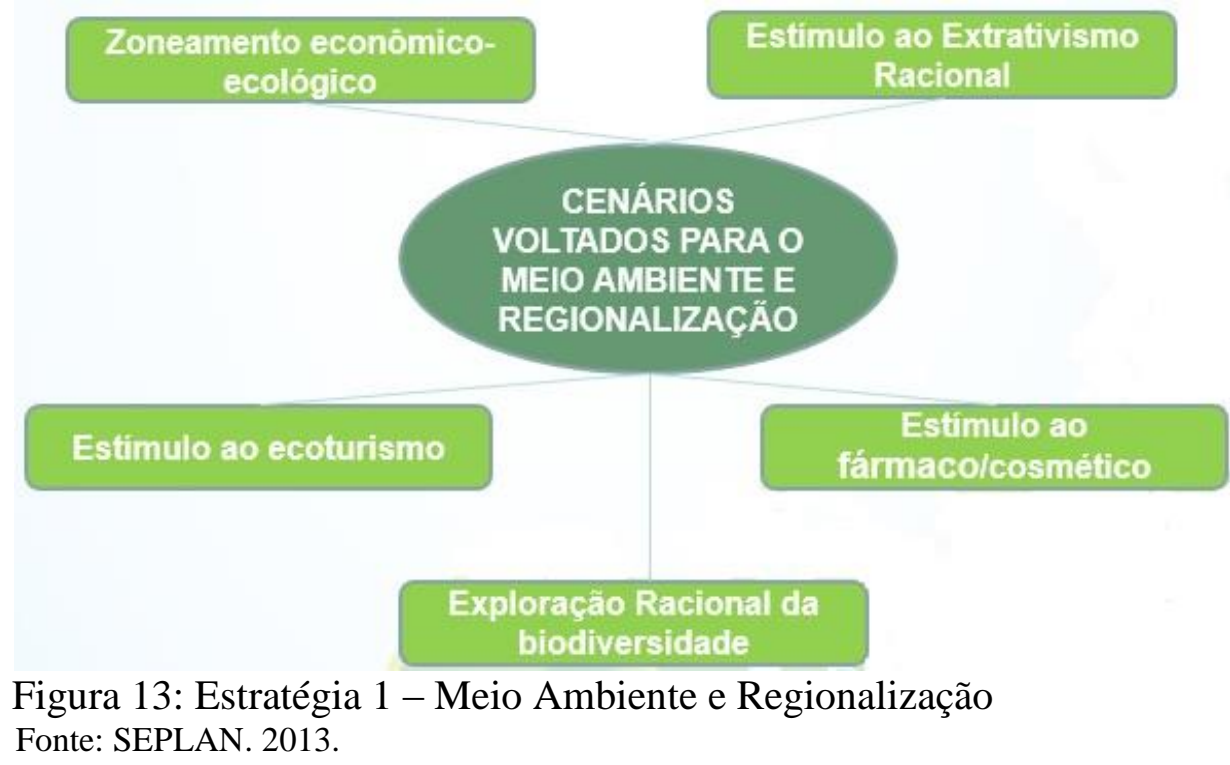


Infraestrutura básica (Cenário 2): complementar a infraestrutura logística de integração inter-regional e internacional de transporte intermodal, reestruturação da matriz energética para o gás, solar e hídrica (Tucuruí e Santo Antônio), bem como a instalação de fibras óticas que permitam uma comunicação efetiva.

Transformação produtiva (Cenário 3): proceder a reestruturação, reconversão e expansão das atividades produtivas do Estado, especialmente do Distrito Industrial da ZFM e a expansão produtiva dos recursos naturais do Amazonas.

Formação de recursos humanos (Cenário 4): Capacitação para demandas do processo produtivo e de acordo com as peculiaridades de seu ambiente vocacional, como, também, das inovações tecnológicas de todos os segmentos (Figura 14).

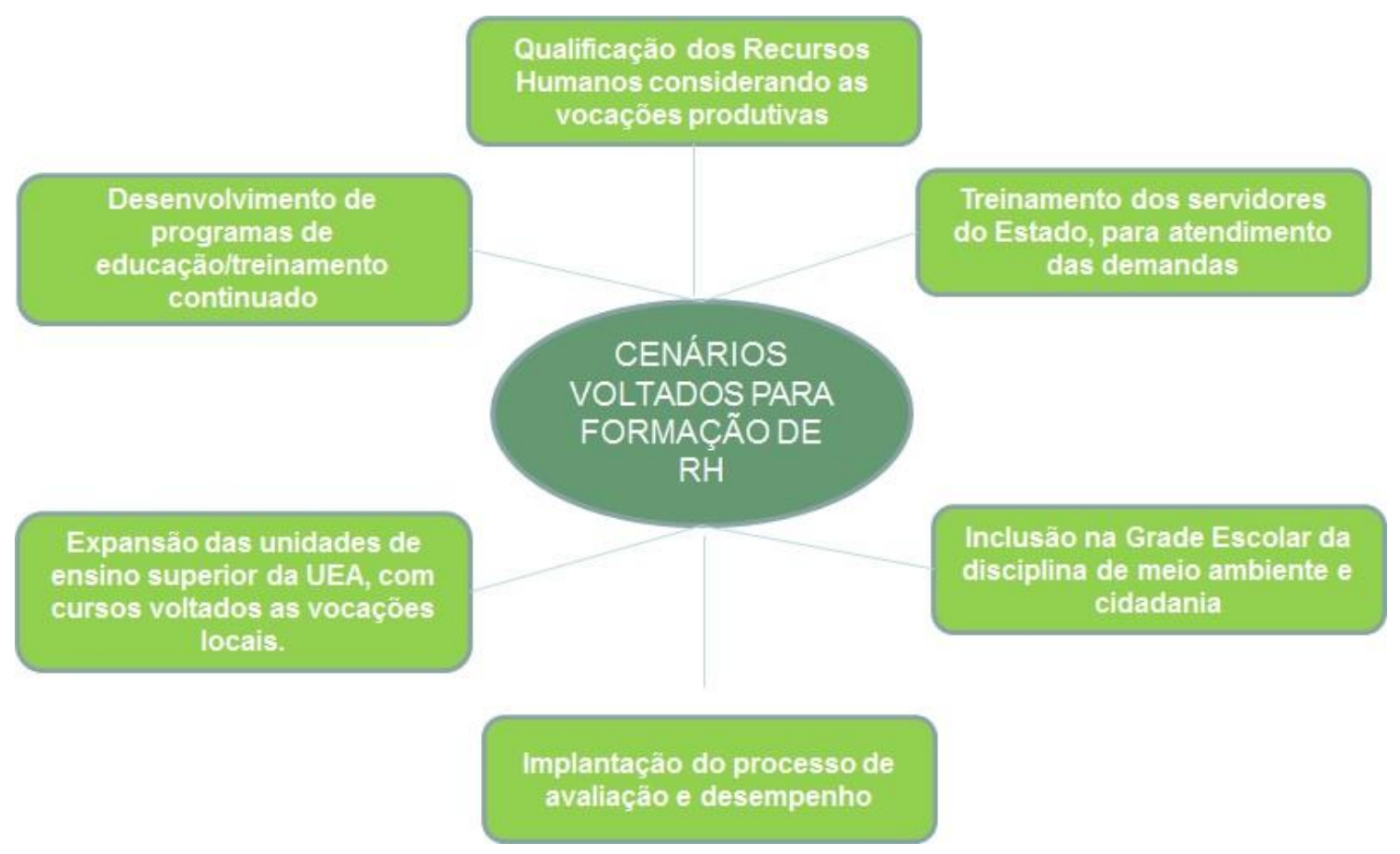

Figura 14: Estratégia 4 - Formação de Recursos Humanos. Fonte: SEPLAN. 2013.

Ciência e tecnologia (Cenário 5): Consolidar a base científica e tecnológica existente no Estado, considerando para as demandas do processo produtivo e de acordo com as peculiaridades local e vocacional ao mesmo tempo em que é necessária uma articulação nacional e internacional, mantendo-se em permanente atualização com a fronteira do conhecimento existente (Figura 15). 


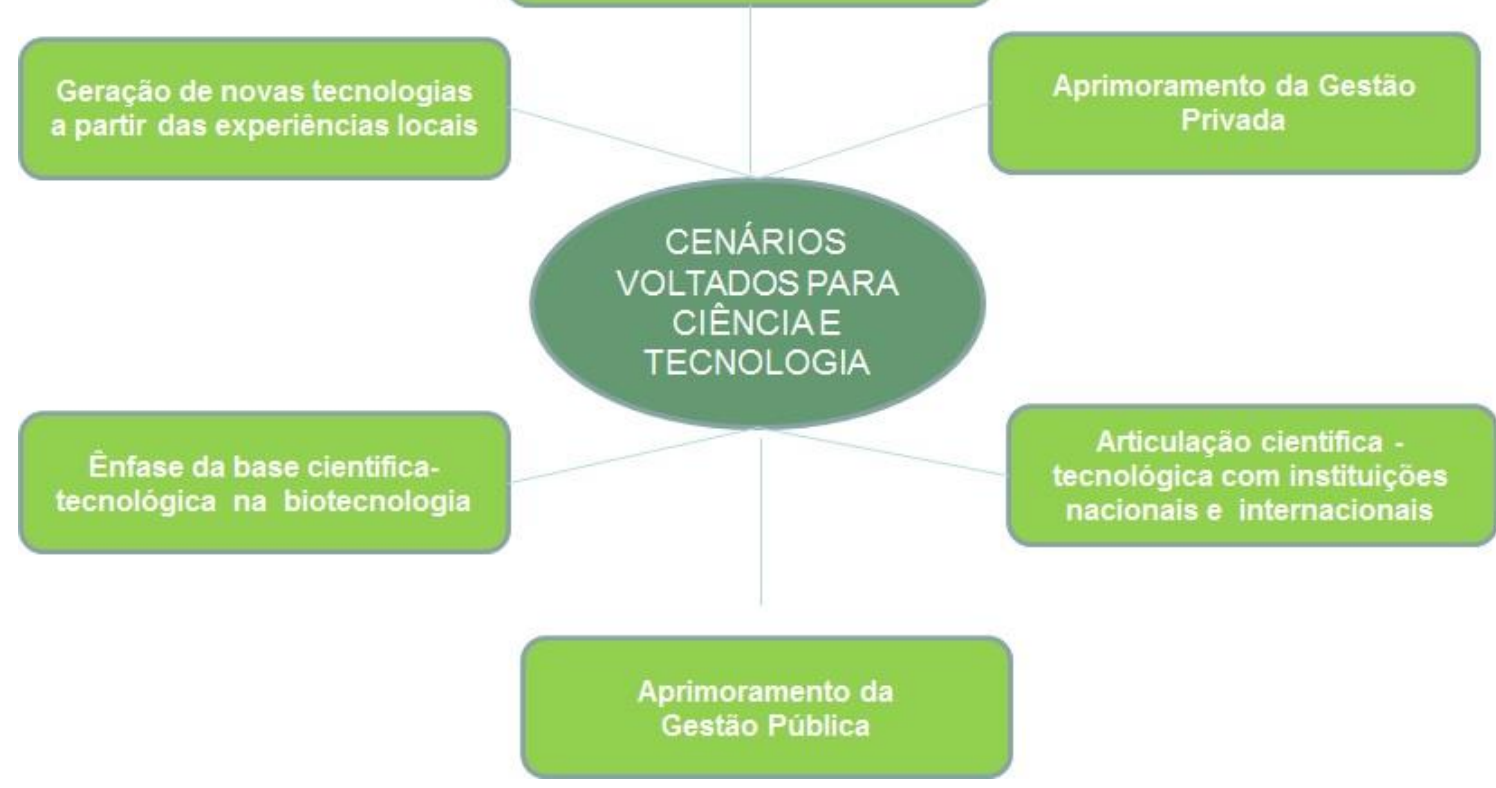

Figura 15: Estratégia 5 - Ciência e Tecnologia.

Fonte: SEPLAN. 2013.

O Planejamento Estratégico deve, portanto, contribuir para o desenvolvimento almejado, pois, requer transformações qualitativas por via de mudanças culturais e o incremento quantitativo devido ao progresso tecnológico que incorpora maior eficiência e dinamismo à estrutura do sistema. A expectativa, deve consistir em encontrar um ponto de equilíbrio social e econômico capaz de maximizar vantagens e benefícios do aceleramento do ritmo de expansão das forças produtivas, cujo benefício será sempre o próprio homem, que é o ator e protagonista deste novo cenário.

A economia deve ser organizada em diversos segmentos e de acordo com as finalidades locais, gerando emprego e renda. A estratégia deve ter como base de partida a intenção de um processo de auto sustentação com base na trilogia - meio ambiente, homem e economia - que deve ser a síntese do desenvolvimento sustentável pretendido a partir da responsabilidade socioambiental (KRAEMER, 2015). 


\section{METODOLOGIA}

\subsection{Classificação da Pesquisa}

O estudo utilizou-se, quanto à natureza, da linha de trabalho caracterizada como pesquisa básica, considerando que tem por premissa gerar conhecimento para solucionar problemas e aprimorar técnicas de observação, interpretação e comparação, primordiais para embasar e certificar os fundamentos pesquisados em literatura, os quais merecem toda consideração. A interpretação leva a investigação baseada nos dados escolhidos pela pesquisa segundo Medeiros (2008).

Com relação a abordagem do problema, trata-se de uma pesquisa quali-quantitativa e descritiva, a partir de dados obtidos para classificá-los e analisá-los, e, também, qualitativa, na medida em que se busca um fenômeno específico em profundidade, com descrições, comparações e interpretações seguindo o método proposto por Silva e Menezes (2005).

Tomou-se por base, a taxonomia de Vergara (2009), que classifica os tipos de pesquisa segundo a ótica dos fins aos quais o estudo se destina, bem como os meios de investigação que foram utilizados. Quanto aos fins, a pesquisa é exploratória e descritiva, uma vez que se realizou em área com pouco conhecimento agregado e, quanto aos meios, é bibliográfica, documental e de campo, pois levantou dados contidos em publicações técnicas e acadêmicas e em observância ao uso de material de órgãos públicos, como planos, relatórios, entre outros.

\subsection{Etapas da Pesquisa}

A investigação se iniciou a partir da identificação de fontes bibliográficas e documentais em atenção ao objetivo específico de descrever o modelo alvo de investimento público do APL de Fitoterápicos (ou fármacos) e Fitocosméticos do Amazonas. Foram caracterizadas as ações do referido modelo proposto, levantando-se os pontos de vista de autores e instituições renomadas no referencial teórico para se ter uma base conceitual.

Foram analisadas para obtenção de informações iniciais referentes aos investimentos públicos, as ações institucionais durante o período de culminância do Programa Plataformas Tecnológicas até o de implantação dos APLs. Os dados obtidos nesta busca documental foram tabulados em planilha Excel e em seguida demonstrados os percentuais em gráficos e tabelas. A mesma metodologia foi aplicada para as empresas investigadas.

Os questionários aplicados possuem questões objetivas relacionadas ao APL dos participantes do Programa Amazonas de Apoio à Pesquisa, Desenvolvimento Tecnológico e 
Inovação em MPEs (PAPPE Subvenção/Integração FINEP-AM), da FAPEAM, em que os clusters foram mapeados segundo interconexão empresarial com a academia e banco de dados.

Esta escolha se deu em função da instituição FAPEAM, do Governo do Estado, apresentar à época da adoção da estratégia, maior identidade com o conjunto dos APLs, em vista da demanda por recursos públicos para a subvenção de pesquisa de C\&T na empresa, incluindo-se neste conjunto o de Fitoterápicos e Fitocosméticos. Das 92 (noventa e duas) empresas participantes do PAPPE-Subvenção/Integração - FAPEAM, identificou-se 20 (vinte) empresas interconectadas de Manaus, sendo que retornaram a entrevista 10 (dez) empresas.

Para as opções incluídas nas perguntas relacionadas ao questionário semiestruturado, foi utilizada a metodologia adotada por Neely e Adams (2001), Caporali e Volker (2004) e Cabete e Dacol (2008). Foram registrados os dados para a composição da análise de 16 (dezesseis) variáveis de medição do desempenho, comparando-se com o questionário empresarial. Para esta métrica, elaborou-se um quadro para consolidar os resultados (Quadro 6).

\begin{tabular}{|c|c|c|c|c|}
\hline & Grupo & Variável & Fonte & Questão \\
\hline 01 & \multirow{5}{*}{ Dados Gerais } & Nível de enquadramento & Portal da Lei Geral & $1^{\mathrm{a}}$. \\
\hline 02 & & Conhecimento do APL & $\begin{array}{c}\text { Caporali e Volker, 2004; } \\
\text { Pimenta, 2014. }\end{array}$ & $2^{\mathrm{a}}$. \\
\hline 03 & & $\begin{array}{l}\text { Instrumento de inserção no } \\
\text { APL }\end{array}$ & Caporali e Volker, 2004 & $3^{\mathrm{a}}$ \\
\hline 04 & & $\begin{array}{l}\text { Inserção nos mercados interno } \\
\text { e externo }\end{array}$ & $\begin{array}{l}\text { Suzigan et al., 2002; } \\
\text { Mendonça, 2008 }\end{array}$ & $4^{\mathrm{a}}$. \\
\hline 05 & & Desenvolvimento Tecnológico & $\begin{array}{c}\text { Suzigan et al., 2002; Lasmar } \\
\text { 2005; Mendonça, } 2008\end{array}$ & $5^{a}$ \\
\hline 06 & \multirow{4}{*}{ Governança/Parcerias } & Especialização Produtiva & $\begin{array}{l}\text { Zacarelli, 1995; Suzigan et } \\
\text { al., 2003; Herculano, } 2014 .\end{array}$ & $6^{\mathrm{a}}$. e $17^{\mathrm{a}}$ \\
\hline 07 & & Estrutura de Governança & $\begin{array}{l}\text { Porter, 2000; Takeda et al., } \\
\text { 2008; Mendonça, } 2008\end{array}$ & $7^{a}$ e $9^{a}$ \\
\hline 08 & & Cooperação Empresarial & $\begin{array}{c}\text { Lasmar 2005; Oliveira et al., } \\
2010\end{array}$ & $8^{\mathrm{a}}$. \\
\hline 09 & & Eficiência Coletiva & Oliveira et al., 2010 & $10^{\mathrm{a}}$. e $11^{\mathrm{a}}$ \\
\hline 10 & \multirow{3}{*}{ Acesso ao Mercado } & Capacidade de competição & $\begin{array}{l}\text { Suzigan et al., 2002; Zaca- } \\
\text { relli, 1995, Mendonça, } 2008 \\
\end{array}$ & $12^{\mathrm{a}}$. \\
\hline 11 & & Desempenho das MPEs & Oliveira et al., 2010 & $13^{\mathrm{a}}$. e $15^{\mathrm{a}}$ \\
\hline 12 & & Trajetória Evolutiva & $\begin{array}{c}\text { Suzigan et al., 2002; Porter, } \\
\text { 1999; Siqueira, 2003, } \\
\text { Mendonça, } 2008\end{array}$ & $14^{\mathrm{a}}$ \\
\hline 13 & $\begin{array}{l}\text { Metodologia Organi- } \\
\text { zacional/Tecnologia }\end{array}$ & Tecnologia da Informação & $\begin{array}{l}\text { Oliveira et al., 2010; Pimenta, } \\
\text { 2014. }\end{array}$ & $16^{\mathrm{a}}$ \\
\hline 14 & $\begin{array}{l}\text { Crédito e Financia- } \\
\text { mento }\end{array}$ & Capital Social & $\begin{array}{l}\text { Oliveira et al., 2010; Pimenta, } \\
\text { 2014. }\end{array}$ & $18^{\mathrm{a}}$. e $19^{\mathrm{a}}$. \\
\hline 15 & Capital Social & Tecido Social & $\begin{array}{c}\text { Suzigan et al., 2002; Siqueira, } \\
\text { 2003, Mendonça, } 2008\end{array}$ & $\begin{array}{c}20^{\mathrm{a}} ., 21^{\mathrm{a}} \cdot \mathrm{e} \\
22^{\mathrm{a}} .\end{array}$ \\
\hline 16 & $\begin{array}{l}\text { Capacidade Tecnoló- } \\
\text { gica }\end{array}$ & Capacitação Tecnológica & $\begin{array}{c}\text { Crocco et al., 2003; Lasmar } \\
\text { 2005; Mendonça, } 2008\end{array}$ & $\begin{array}{c}23^{\mathrm{a}} \cdot, 24^{\mathrm{a}} \cdot \mathrm{e} \\
25^{\mathrm{a}} .\end{array}$ \\
\hline
\end{tabular}

Quadro 6 - Variáveis selecionadas para a medição do desempenho do APL

Fonte: elaborado pelo autor. 
Estas variáveis foram escolhidas em função da compatibilidade de estudos de sucesso apontados na literatura, adotando-se alguns critérios dos autores para analisar resultados do presente estudo, como, por exemplo, Galdámez, Suzigan, Lastres, Cassiolato, Oliveira, Caporali, Volker, entre outros.

A utilização das variáveis do Quadro 5 representa, então, uma proposta de Indicadores de Desempenho (IDs) associados ao processo de gestão do desempenho do APL em estudo. Tais IDs, segundo Oliveira et al (2010), devem servir dentro dos objetivos do estudo para uma avaliação dos resultados alcançados com o investimento público no APL em estudo, o que deverá propiciar, consequentemente, o fortalecimento do processo de decisão dos atores de governança local (SEBRAE, SEPLAN, Sindicato, entre outros), o desenho do contexto da economia local da atividade industrial (pessoas ocupadas e qualificadas, produtividade) e, a promoção da cooperação e coordenação do processo de inovação contínua.

Seguindo a metodologia para o levantamento das informações, das 20 (vinte) empresas identificadas, foram entrevistadas 10 (dez) empresas de Manaus que mantiveram interface com o referido modelo (Quadro 7). As demais não responderam ou não foram localizadas.

\begin{tabular}{|c|c|c|c|}
\hline Legenda & Nome da empresa & Fundação & Linha de Produção \\
\hline 1 & $\begin{array}{l}\text { Pronatus } \\
\text { Amazonas }\end{array}$ & 1986 & $\begin{array}{l}\text { Capilar, corpo, higiene bucal, mãos/pés, } \\
\text { massagem corporal, unhas, filtro solar e } \\
\text { bronzeador, repelente e rosto/face, mel para tosse. }\end{array}$ \\
\hline 2 & Magama Industrial & 1993 & $\begin{array}{l}\text { Lapacho (óleo essencial de pau rosa) e óleo } \\
\text { essencial (exceto de pau rosa e copaíba) standard. }\end{array}$ \\
\hline 3 & $\begin{array}{l}\text { Pharmakos } \\
\text { D’Amazônia }\end{array}$ & 2001 & $\begin{array}{l}\text { Xampu, sabonetes, óleos, loção hidratante, gel, } \\
\text { condicionador e bronzeadores, mel para tosse. }\end{array}$ \\
\hline 4 & Amazon Ervas & 1997 & $\begin{array}{l}\text { Preparações para cabelo (xampu) e preparações } \\
\text { para cabelo (condicionador) }\end{array}$ \\
\hline 5 & Oiram & 1998 & $\begin{array}{l}\text { Preparações de chocolates e biscoitos com } \\
\text { recheio de frutas amazônicas. }\end{array}$ \\
\hline 6 & Ecobios & 2017 & $\begin{array}{l}\text { Produção de bioprodutos como biossurfactantes e } \\
\text { plásticos biodegradáveis. }\end{array}$ \\
\hline 7 & $\begin{array}{l}\text { Temperos } \\
\text { Amazônia }\end{array}$ & 2012 & $\begin{array}{l}\text { Preparações para molhos e temperos à base de } \\
\text { ervas amazônicas. }\end{array}$ \\
\hline 8 & Agrosol & 2005 & Preparações à base de óleos vegetais. \\
\hline 9 & Loja das Essencias & 2006 & Colônias líquidas, perfumes, loções. \\
\hline 10 & Amazoe Ltda & 1998 & $\begin{array}{l}\text { Compostos nutricionais à base de soja com ervas } \\
\text { amazônicas. }\end{array}$ \\
\hline
\end{tabular}

Quadro 7 - Empresas pesquisadas

Fonte: Dados da pesquisa.

A análise dos resultados dos questionários, se deu de acordo com os objetivos propostos, que tem como escopo a procura do sentido mais amplo das respostas por sua ligação com outros conhecimentos já obtidos, realizando-se uma comparação com a teoria. 
Para a construção da Matriz SWOT foi adotado o modelo apresentado no Quadro 8, em que se registraram as situações relevantes, sendo o que foi visto de positivo em suas operações atuais são os pontos fortes e o que foi visto pelas empresas como negativo são os pontos fracos. O que foi levantado como bom aos APLs no ambiente externo em termos de futuras operações são as oportunidades de melhoria no desempenho; o que foi levantado como ruim são ameaças. Desta forma, a metodologia busca um feedback dos envolvidos como meio de comparação e constatação dos resultados da abordagem.

Com base em Montana e Charnov (2005) e Oliveira (2004) os passos para utilização da técnica do SWOT incluem a geração de uma lista com as organizações chave, tendo em vista a análise da opinião, com o intuito de levantar questões vitais com base na suposição de que os fatos de uma empresa são encontrados na memória dos protagonistas.

\begin{tabular}{|l|c|c|}
\hline$\rightarrow$ Pontos & Positivos & Negativos \\
\hline$\downarrow$ Ambiente & FORÇAS (S) & FRAQUEZAS (W) \\
\hline Internos & & AMEAÇAS (T) \\
\hline & OPORTUNIDADES (O) & \\
\hline Externos & & \\
\hline
\end{tabular}

Quadro 8 - Modelo de estrutura para a construção da Matriz SWOT.

Fonte: Adaptado pelo autor.

Esta metodologia permite diagnosticar o perfil da maturidade ${ }^{26}$ do cluster sob um enfoque sistêmico do APL, ou seja, desafio a desafio, analisando suas relações com fatores externos e internos à empresa e apresentando seus pontos fortes e fracos.

$\mathrm{O}$ trabalho de pesquisa incluiu também consulta à base de dados da FAPEAM $^{27}$ para o mapeamento dos clusters quanto às atividades realizadas das empresas subvencionadas pelo PAPPE em sua edição coordenada por esta instituição. Trata-se de uma consulta aos relatórios empresariais apresentados à instituição com resultados das ações desenvolvidas do projeto. Desta forma, é importante considerar o todo em que ela está inserida e não somente suas práticas individuais, pois a prática coletiva também influencia em seu desenvolvimento individual.

\footnotetext{
$26 \mathrm{Na}$ literatura especializada são encontrados poucos métodos para avaliação da maturidade dos APL especificamente, e a maioria destes trabalhos parte da adaptação de modelos de avaliação empresarial tentando adequá-los a este tipo de organização. Souza (2004) avalia a maturidade do APL com base em indicadores de desempenho de competitividade do sistema e não de cada ator ou empresa do APL isoladamente. Desta forma, o modelo é adequado a APL que possuam certo grau de estruturação capaz de permitir a obtenção de indicadores.

${ }^{27}$ A FAPEAM fomenta a pesquisa científica, o desenvolvimento tecnológico, a inovação e a formação de recursos humanos para o desenvolvimento social e econômico sustentável do Estado do Amazonas (SECT). Criada em 2003, a FAPEAM assumiu o fomento das pesquisas básicas. As parcerias com agências nacionais foram decisivas para a consolidação do fomento à pesquisa estadual, a exemplo das firmadas com o MCT e suas agências, como a FINEP e o CNPq, com destaque para o Programa de Apoio a Núcleos de Excelência - PRONEX.
} 


\section{RESULTADOS E DISCUSSÃO}

\subsection{DAS AÇões DO PROGRAMA PLATAFORMAS TECNOLÓgICAS ATÉ A ADOÇÃO DA ESTRATÉGIA DE ARRANJOS PRODUTIVOS}

A pesquisa identificou o Programa Plataformas Tecnológicas como uma fase embrionária do APL no Estado do Amazonas, analisadas no presente estudo, com destaque nas seguintes ações:

- Criação do grupo de trabalho (GT) de 'COOPERAÇÃO E GOVERNANÇA' para participação das instituições, sendo os atores: SEDEC, FUCAPI, INPA, UFAM, PRONATUS, IBAMA, IPAAM, MCT, Bioamazônia, SIPEAM, UEA, IPT, FAM, HMTM, HUGV, ABIN, SEBRAE, SUFRAMA; e os articuladores: FUCAPI, SEDEC, PRONATUS.

- Criação do GT de FORMAÇÃO/CAPACITAÇÃO com participação do Instituto Nacional de Pesquisas da Amazônia - INPA e Universidade Federal do Amazonas - UFAM.

- Elaboração do Projeto "Desenvolvimento de dois produtos Fitoterápicos (Muirapuama e Chichuá) e um Fitocosmético (Crajiru) a partir de espécies Amazônicas", formatado a partir da escolha destas três plantas, conforme orçamento da Tabela 1.

\begin{tabular}{l|c|c|r}
\hline \multicolumn{1}{c|}{ Quadro de Fontes } & $\begin{array}{c}\text { Recursos } \\
\text { Financeiros }\end{array}$ & $\begin{array}{c}\text { Recursos Não } \\
\text { Financeiros }\end{array}$ & \multicolumn{1}{c}{ TOTAL } \\
\hline FINEP / FNDCT & $741.642,00$ & - & $741.642,00$ \\
\hline FUCAPI (Proponente) & - & - & - \\
\hline INPA (Executor) & - & $471.600,00$ & $471.600,00$ \\
\hline UFAM (Co executor) & - & $60.000,00$ & $60.000,00$ \\
\hline SEDEC (Interveniente) & - & $15.000,00$ & $15.000,00$ \\
\hline PRONATUS (Interveniente) & - & $72.000,00$ & $72.000,00$ \\
\hline TOTAL GERAL & $741.682,00$ & $618.600,00$ & $1.360 .282,00$ \\
\hline
\end{tabular}

Tabela 1 - Orçamento do projeto Desenvolvimento de dois produtos Fitoterápicos e um Fitocosmético a partir de espécies Amazônicas

Fonte: Formulário APL/FNDCT. SEDEC (atual SEPLANCTI). 2001.

- Para atender o referido projeto acima foi criado por meio da Portaria 003/2002 GS/SEDEC, o Comitê Consultivo Setorial de Biotecnologia, responsável por demandar a integração dos esforços do setor público e do privado. Um dos seus objetivos era formalizar parcerias e propor alternativas de programas e projetos que resultassem em investimentos hábeis e geração de valor adicionado, emprego e renda. O referido objetivo auxiliou na validação de projetos como: Plataformas Tecnológicas, Cadeias Produtivas, APLs e a concessão de incentivos fiscais e extrafiscais. 
- Edição da Lei 2.743, de julho/2002, a qual autorizou o Poder Executivo a instituir a FAPEAM e outras providências.

Após estas definições houve a criação da SEPLAN em 2003, com a adoção de mecanismo de consulta local para a elaboração do PPA 2004 2007, da SECT e da FAPEAM, criada para assumir, entre outras, o fomento das pesquisas básicas, iniciou parcerias com agências nacionais que foram decisivas para a consolidação do fomento à pesquisa, a exemplo das firmadas com o MCT e agências, como FINEP e CNPq.

A SECT (inclusa na atual SEPLANCTI) encampou o programa Plataformas Tecnológicas na esfera estadual por intermédio do Núcleo de Gestão Compartilhada - NGTC, se constituindo em um apoio vital, posto que teria a missão prioritária de apoiar a manutenção e agregar novos recursos financeiros e, especialmente, gerar conhecimentos que contribuíssem para a gestão do plano e a transferência, para a economia local, das soluções tecnológicas encontradas.

Os resultados a seguir, obtidos desta fase de transição entre Plataformas Tecnológicas com o NGTC e os Arranjos Produtivos Locais, com o NEAPL, foram sintetizadas em um quadro (Anexo 1) a partir das ações relacionadas no Plano de Desenvolvimento Preliminar do APL de Fitoterápicos e Fitocosméticos, incluindo o projeto piloto do Programa Plataformas Tecnológicas e as demais ações que se sucederam no modelo alvo.

Como algumas ações realizadas e previstas no orçamento para investimento no período de 2001-2008 não apresentaram valor devido ao fato de não constar no referido plano, estas foram consideradas na soma do 'número total de ações' para efeito de análise.

As ações do APL de Fitoterápicos e Fitocosméticos no período de 2001 a 2008 apresentadas no Gráfico 1, registrou-se um total de 13 (treze) ações realizadas e em andamento, declinando para 10 (dez) ações previstas no PDP em outubro/2008, representadas, respectivamente, por $57 \%$ e $43 \%$, do total das ações levantadas.

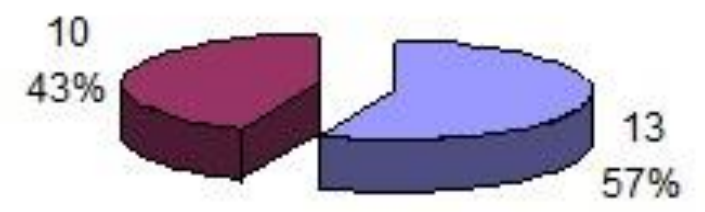

$\square$ REALIZADAS

PREVISTAS

Gráfico 1 - Ações Realizadas e Previstas: APL Fitoterápicos e Fitocosméticos. Fonte: Seplan, 2013.

Os Gráficos 2 e 3 apresentam os dados da pesquisa da origem do investimento financeiro em valores absolutos e percentuais. O APL obteve no período de 2001 2008 um 
total de $\mathrm{R} \$ 1.612 .278,46$, na viabilização financeira nas ações realizadas e em andamento, resultado da soma de $\mathrm{R} \$ 1.186 .298,37$ oriundo de fonte federal (74\%), mais $\mathrm{R} \$ 424.480,09$ de fonte estadual (26\%) e de $\mathrm{R} \$ 1.500,00$ do local. O maior aporte, portanto, foi de fonte federal.

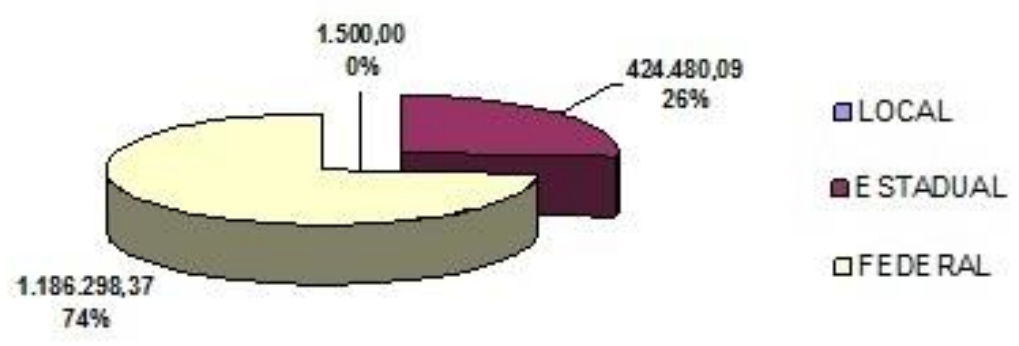

Gráfico 2 - Viabilização financeira nas ações realizadas e em andamento Fonte: Seplan, 2013.

É possível visualizar no Gráfico 3, da viabilização financeira nas ações previstas, que o Governo Federal previu investimentos de R \$ 9 milhões, o Estadual pouco mais R \$ 6 milhões, totalizando R \$ 15.016.015,00 previstos no final de 2008, um aumento de 831,35\% em relação a todo o período de 2001 2008. Aqui também a iniciativa federal venceu com $60 \%$ dos investimentos.

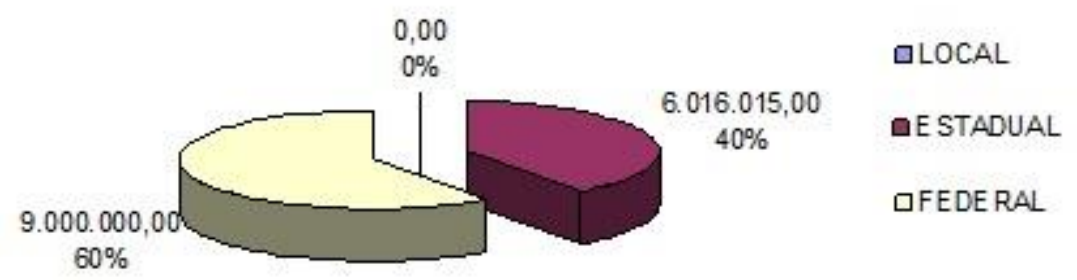

Gráfico 3 - Viabilização financeira nas ações previstas Fonte: Seplan, 2013.

Segundo Thury et al (2010) os dados apresentados de viabilização financeira remetem a um ponto crítico de discussão que é o fato de não se notar a existência de um sistema de avaliação mais robusto dos resultados das ações de apoio ao APL, capaz de contribuir para corrigir os rumos da atuação, apontando, por exemplo, um registro da operacionalização dos recursos previstos no final de 2008.

Seguindo com os dados da pesquisa, conforme se observa no Gráfico 4, do total de 13 (treze) ações realizadas e em andamento no período, onze (11) delas estavam direcionadas para o 'Resultado 1 - Aumento da produção e da produtividade', segundo o que foi definido pelos stakeholders no Plano de Desenvolvimento Preliminar do referido APL, o que representou 85\% do somatório das ações. 


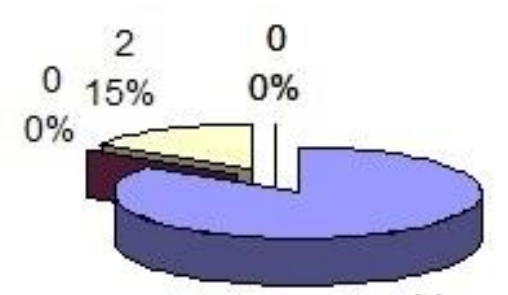

11

$85 \%$ $\square R 1$ - A umento da prod. e produtiv., visando ampliar o mercado, $\mathrm{c} /$ prod. padronizado e certificado

$\square R 2$ - Difusão do associativismo e cooper ativismo

$\square R 3$ - Infra-estrutura de industrial. adequada e qualif. profissional

口R4 - Sistemr logístico adequado

- R5 - Legalizações e licenças

Gráfico 4 - Resultados das ações realizadas - APL de Fitoterápicos e Fitocosméticos Fonte: Seplan, 2013.

Também nas ações previstas, conforme se observa no Gráficos 5, prevaleceram o 'Resultado 1 (R1) - Aumento da produção e da produtividade', com 6 (seis) ações que representaram $60 \%$ do total, e o 'Resultado 3 (R3) - Infraestrutura de Industrialização adequada e qualificação profissional', com 4 (quatro) ações que representaram $40 \%$ do total.
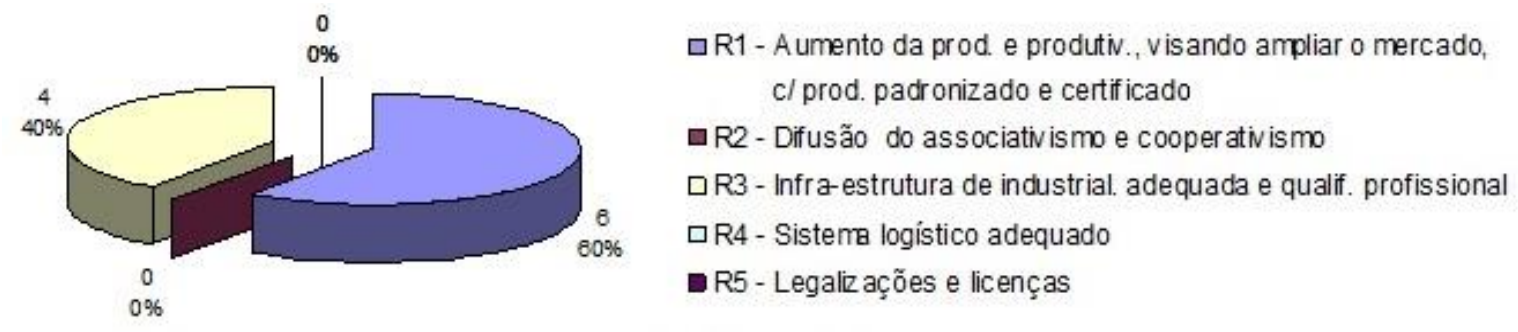

Gráfico 5 - Resultados das ações previstas - APL de Fitoterápicos e Fitocosméticos Fonte: Seplan, 2013.

Em relação ao agrupamento por "Item relacionado" (Gráfico 6), nota-se que a maior parte das ações realizadas neste APL se deu em "tecnologia e inovação", com 12 (doze) ações. Registrou-se uma ação em "formação e capacitação" e os demais itens não registraram nenhuma ação. Nas ações previstas, percebe-se a redução pela metade do número de ações em "tecnologia e inovação", registrando 3 (três) ações em "investimento e financiamento" e 1 (uma) ação em “formação e capacitação". Os demais itens não registraram nenhuma ação.

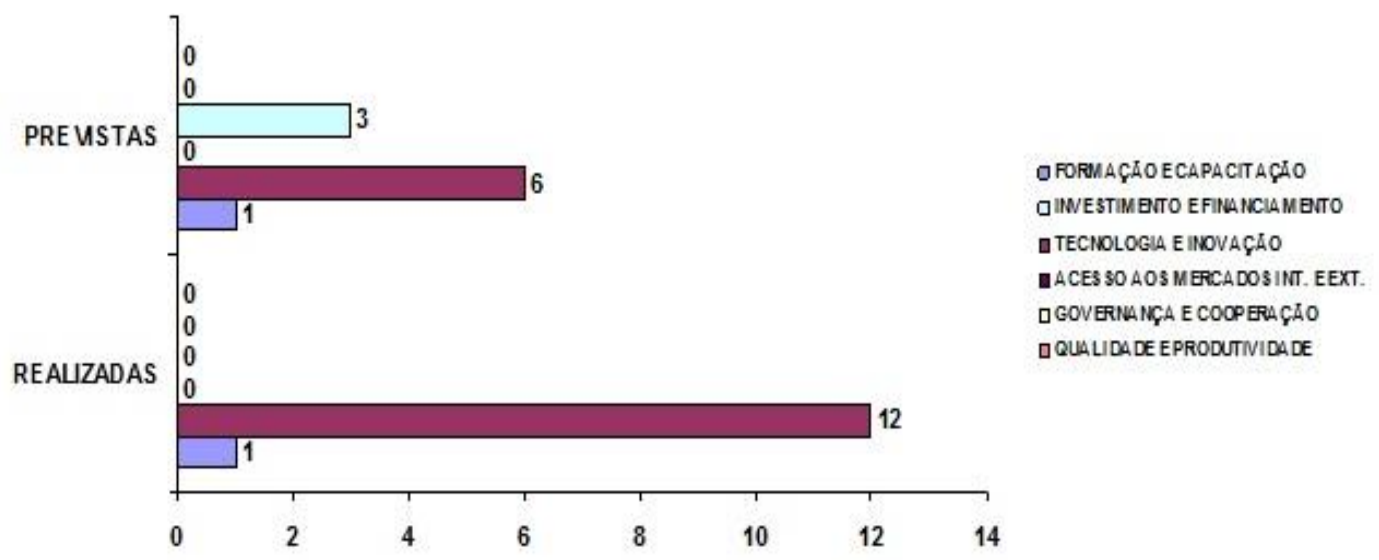

Gráfico 6 - Item relacionado por ações - APL de Fitoterápicos e Fitocosméticos. Fonte: Seplan, 2013. 
Buarque (2002) enfatiza que a transformação nas bases econômicas resulta na organização e mobilização social, além da exploração de capacidades e potencialidades específicas, o que pode ser apontado como um fator para atendimento das 5 (cinco) prioridades apontadas nos referidos resultados desse trabalho.

Quanto à participação dos parceiros, observa-se no Gráfico 7 que houve maior número de parcerias federais (22) nas ações realizadas e em andamento, enquanto que nas previstas registrou-se um empate entre federais e estaduais, com 13 (treze) registros de parcerias.

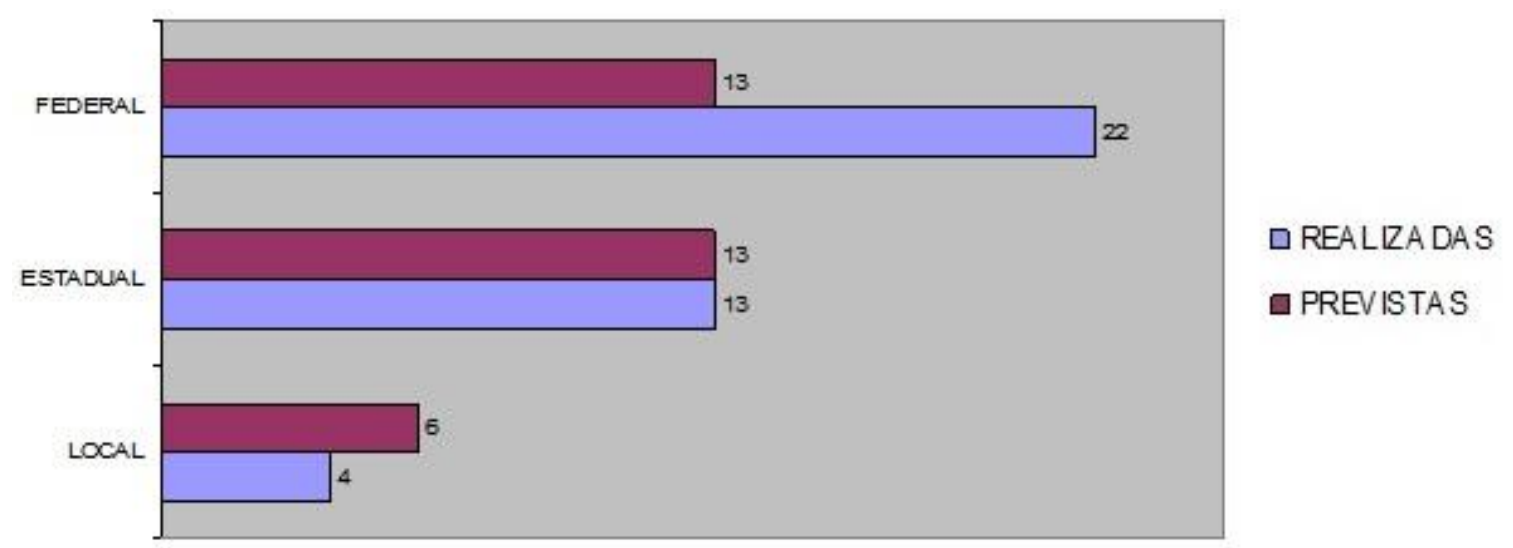

Gráfico 7 - Número de parcerias nas ações do APL de Fitoterápicos e Fitocosméticos. Fonte: Seplan, 2013.

Com relação aos resultados obtidos desta primeira fase do APL em estudo, Thury et al (2010) afirma que o padrão de apoio, como em outros APLs, foi sedimentado na presença massiva do governo, quer dizer, a iniciativa, condução, planejamento, recursos financeiros e, em muitos casos, até parte da operacionalização foram assumidos por entes governamentais.

Este caminho representou um grave risco, pois APLs forjados e conduzidos majoritariamente pela esfera pública, passaram a uma lenta alavancagem ${ }^{28}$, notando-se pouco aparecimento ou difusão do capital social e empreendedorismo com recursos próprios ou financiado por terceiros, principalmente quando se observa que os recursos públicos dominaram o financiamento das ações.

Em consequência, não se observa nesta fase do APL em estudo, existência de lideranças mais atuantes e expressiva participação nas exportações. Esse baixo peso, segundo Thury et al (2010), decorre do vulto do PIM. De todo modo, a falta de maior presença no comércio exterior prejudicou, de algum modo, o aprendizado econômico, organizacional e tecnológico, na medida em que esta experiência levaria ao aumento de produção e produtividade. Esse ponto

\footnotetext{
28 Termo utilizado para definir todo tipo de técnica utilizada com o intuito de multiplicar a rentabilidade. Tal prática resulta do usufruto dos recursos de terceiros dentro do capital da empresa. A organização se utiliza de ativos e recursos externos, tomados em forma de financiamento com o objetivo de aumentar o lucro (Portal IBC).
} 
traz à tona uma notória dificuldade do interior do Estado que é a grande distancia do principal centro de distribuição, Manaus, caracterizando problemas de logística, agravados pela dispersão de municípios com certa densidade demográfica e outros desafios de infraestrutura.

O modelo alvo adotado como estratégia para o trabalho com APLs, não deixa claro a conexão entre produtos e segmentos, como, por exemplo, no caso dos Fitoterápicos (ou Fármacos) e dos Fitocosméticos, que para o fortalecimento e alavancagem dos clusters, poderiam ter formado um APL da Bioindústria ou Bioprodutos, bem mais abrangente e representativo para a formação de um APL robusto em quantidade de empresas.

Isto ocorreu por ter se optado no Estado pela designação dos APLs a partir de produtos, e não de segmentos econômicos, como foi o caso da Fécula e Farinha de Mandioca, por exemplo, que poderia estar inserido em um APL de Agroindústria. Como o Governo Federal limitou o número de APLs, isso concorreu para que localidades e atores sem interesses comuns ficassem em um mesmo APL, embora não configurem territórios geograficamente contíguos.

A categoria do APL de Fitoterápicos e Fitocosméticos do Amazonas, de acordo com Thury et al (2010) se encontra espremida, de um lado, pela concepção de potencialidade associada à oferta de recursos, ainda que este nem se apresente como oportunidades de negócios, e, de outro, por segmentos de maior participação no valor adicionado estadual, ligados à ZFM, tratados ora como polos, ora como subsetores ou cadeias produtivas.

\subsection{DA PESQUISA DO DESEMPENHO DAS EMPRESAS}

As informações foram obtidas do questionário aplicado em empresas interconectadas do APL selecionadas da FAPEAM ${ }^{29}$, mais especificamente, do Programa Amazonas de Apoio à Pesquisa, Desenvolvimento Tecnológico e Inovação em MPEs - PAPPE/AM, incluindo as entidades FINEP, MCT, SEPLANCTI, AFEAM, SEBRAE, IDAM, IEL, nas modalidades de Subvenção e Integração (Tabela 2).

\begin{tabular}{l|c|r|r|c}
\hline \multirow{2}{*}{ Programa PAPPE/AM } & Qtde. MPEs & \multicolumn{3}{|c}{ Investimento (R\$) } \\
\cline { 3 - 5 } & beneficiadas & \multicolumn{1}{c|}{ FAPEAM } & \multicolumn{1}{c}{ FINEP } & \multicolumn{1}{c}{ TOTAL } \\
\hline FINEP 2004-2009 / Edital 007/2004 & 25 & $1.972 .073,00$ & $1.881 .670,00$ & $3.853 .743,00$ \\
\hline Subvenção/AM 2008 - Edital 008/2008 & 23 & $1.150 .660,95$ & $2.301 .321,90$ & $3.451 .982,85$ \\
\hline Subvenção/AM 2009 - Edital 017/2008 & 19 & $897.389,68$ & $1.794 .779,36$ & $2.692 .169,04$ \\
\hline INTEGRAÇÃO 2011 - Edital 003/2011 & 25 & $2.201 .421,02$ & $4.101 .412,01$ & $6.302 .833,03$ \\
\hline TOTAL & 92 & $7.546 .256,31$ & $10.079 .183,27$ & $17.625 .439,58$ \\
\hline
\end{tabular}

Tabela 2 - Programas FAPEAM/FINEP-MCT interconectados com os APLs.

Fonte: Dados da Pesquisa.

29 A FAPEAM fomenta a pesquisa científica, o desenvolvimento tecnológico, a inovação e a formação de recursos humanos para o desenvolvimento social e econômico sustentável do Estado do Amazonas (SECTI). 
Do total de 92 (noventa e duas) participantes de subvenção (tabela 2) no período de 2004 a 2011, foram identificadas 20 (vinte) empresas interconectadas, das quais 10 (dez) responderam ao questionário da pesquisa a fim de se obter resultados observados durante suas participações no modelo alvo de APLs (Quadro 9).

\begin{tabular}{|c|c|c|}
\hline \multicolumn{3}{|l|}{ PAPPE 2004} \\
\hline Área & N. de Empresas & Valor $(\mathbf{R} \$)$ \\
\hline Fitofármacos (ou fitoterápicos) e cosméticos & 5 & $918.957,00$ \\
\hline Softwares & 4 & $497.914,00$ \\
\hline Alimentos & 2 & $367.250,00$ \\
\hline Artefatos e artigos amazônicos & 2 & $234.984,00$ \\
\hline Geração de energia & 2 & $269.557,00$ \\
\hline Piscicultura & 2 & $275.557,00$ \\
\hline TOTAL & & $2.562 .881,00$ \\
\hline \multicolumn{3}{|l|}{ PAPPE 008/2008 } \\
\hline Área & N. de Empresas & Valor $(\mathbf{R} \$)$ \\
\hline Fitofármacos (ou fitoterápicos) e cosméticos & 5 & $646.371,13$ \\
\hline Pesca e Piscicultura & 1 & $143.004,00$ \\
\hline Madeira e Móveis & 1 & $199.840,00$ \\
\hline Indústria de Cerâmica & 1 & $192.370,00$ \\
\hline Alimentos & 5 & $899.114,54$ \\
\hline Construção Civil & 1 & $110.964,44$ \\
\hline Artefatos de Couro, Palha e Vime & 3 & $368.984,99$ \\
\hline Indústria de Plásticos & 2 & $295.786,23$ \\
\hline Informática & 1 & $199.934,00$ \\
\hline Energia & 1 & $102.697,50$ \\
\hline Serviços de Ensaios, Testes e Análises & 1 & $140.316,02$ \\
\hline TOTAL & & $3.299 .382,85$ \\
\hline \multicolumn{3}{|l|}{ PAPPE 017/2008 } \\
\hline Área & N. de Empresas & Valor $(\mathbf{R} \$)$ \\
\hline Fitofármacos (ou fitoterápicos) e cosméticos & 1 & $130.000,00$ \\
\hline Informática & 2 & $451.801,66$ \\
\hline Polo Cerâmico Oleiro & 1 & $164.470,23$ \\
\hline Produtos e Serviços Ambientais & 1 & $177.797,80$ \\
\hline Produção de Pescado & 1 & $191.000,00$ \\
\hline Madeira, Móveis e Artefatos & 2 & $318.771,00$ \\
\hline Artesanato, Produtos e Serviços & 1 & $106.270,00$ \\
\hline Turismo Ecológico & 2 & $332.018,00$ \\
\hline $\begin{array}{l}\text { Polpas, Extratos e Concentrados de Frutas } \\
\text { Regionais }\end{array}$ & 1 & $135.618,12$ \\
\hline $\begin{array}{l}\text { Construção Naval, Produtos e Serviços } \\
\text { Ambientais }\end{array}$ & 1 & $128.542,00$ \\
\hline Castanha do Brasil & 1 & $154.665,00$ \\
\hline TOTAL & & $2.290 .953,18$ \\
\hline
\end{tabular}

Quadro 9 - Área de Concentração, Número de Empresas e Investimentos dos Projetos do PAPPE: edições 2004 e 2008.

Fonte: Relatório de Atividades FAPEAM. 2010. 


\subsubsection{DADOS GERAIS DAS EMPRESAS}

Neste primeiro grupo de questões foram reunidas as variáveis que possibilitam o conhecimento geral dos empreendimentos participantes do estudo. Buscou-se, então, definir de que forma as empresas se relacionam com estes fatores, agrupando-as em 5 aspectos gerais, que contemplam ações pertinentes a elas.

\subsubsection{Nível de enquadramento da empresa}

Foi questionado em qual nível de enquadramento a empresa se encontrava, se era micro, pequena, média ou até grande empresa. A totalidade das 10 (dez) empresas entrevistadas respondeu que se enquadravam no nível de Empresas de Pequeno Porte - EPP, ou seja, no conjunto das empresas com faturamento anual máximo de $\mathrm{R}$ \$,8 milhões/ano, segundo a legislação do Simples Nacional que consta no Portal da Lei Geral.

Constata-se com este resultado que as empresas demonstraram compatibilidade no enquadramento da política do Governo do Estado com o PAPPE-Subvenção da FAPEAM, pois, como defende Galdámez (2009), isso acontece devido a tendência das micro e pequenas empresas - MPEs, que a partir de agrupamentos ou aglomerações, buscam alavancar os lucros dos empreendedores aproveitando essas intervenções governamentais.

\subsubsection{Conhecimento do instrumento APLs}

Questionou-se como a empresa conheceu a estratégia dos APLs. Das empresas entrevistadas, $40 \%$ responderam que foi por meio do Grupo de Trabalho do APL, 20\% por meio do NEAPL ou da Câmara Setorial e 30\% por outro tipo (Gráfico 8).

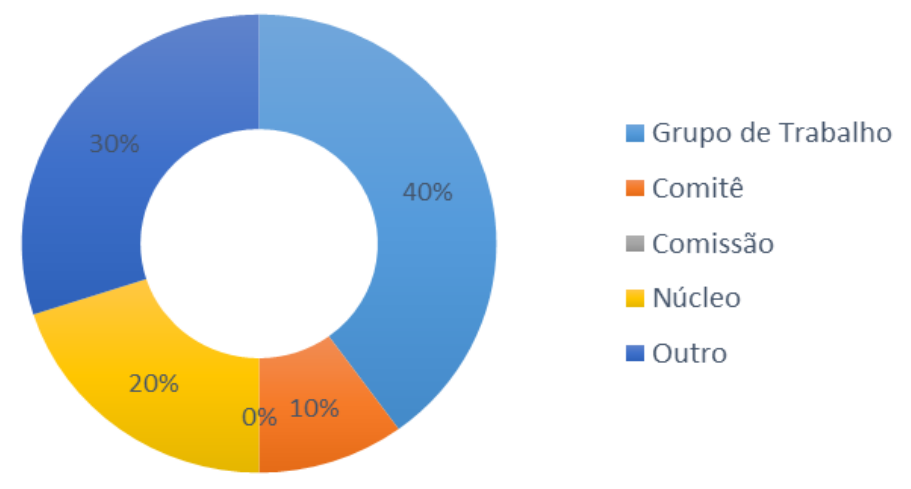

Gráfico 8 - Conhecimento do instrumento APLs Fonte: Dados da pesquisa.

A totalidade das empresas participantes, considerando a referida variável, obteve o conhecimento do instrumento APLs, por intermédio de editais governamentais e/ou convites formais dos referidos órgãos, além de seminários e palestras nos órgãos de planejamento, o que significa eficiência na disseminação da estratégia. 
Observando o que afirma Amato (2009), um APL precisa acumular vários tipos de conhecimento (tácito, explícito e científico) e o acesso deve ser garantido para as MPEs que estão concentradas geograficamente e participando do cluster. Assim, esse resultado ocorre porque os relacionamentos pessoais e os laços que existem no segmento promovem uma certa confiança e o fluxo de informações, podendo facilitar com isso uma capacidade tecnológica e de produção no local/região.

Para Caporali e Volker (2004) esse agrupamento estimula uma consciência coletiva com o objetivo de visualizar e entender o APL como um todo, definindo o papel e a importância de cada ator, organizando e definindo os critérios e as rotinas de participação coletiva. Mobiliza os empresários a participarem do planejamento das atividades do arranjo e a sentirem-se responsáveis pelo seu sucesso ou fracasso.

\subsubsection{Momento de inserção da empresa no instrumento APL}

Perguntou-se em que momento aconteceu a inserção da empresa no modelo alvo. Esta variável serviu para a identificação de programas, ações, entre outros, capazes de arregimentar para o APL. O resultado apontou um total de 50\% por meio do modelo de 'APLs SEPLAN/2007' e 30\% responderam que foi por meio do 'Programa Plataformas Tecnológicas MCT/2001', conforme se visualiza no Gráfico 9.
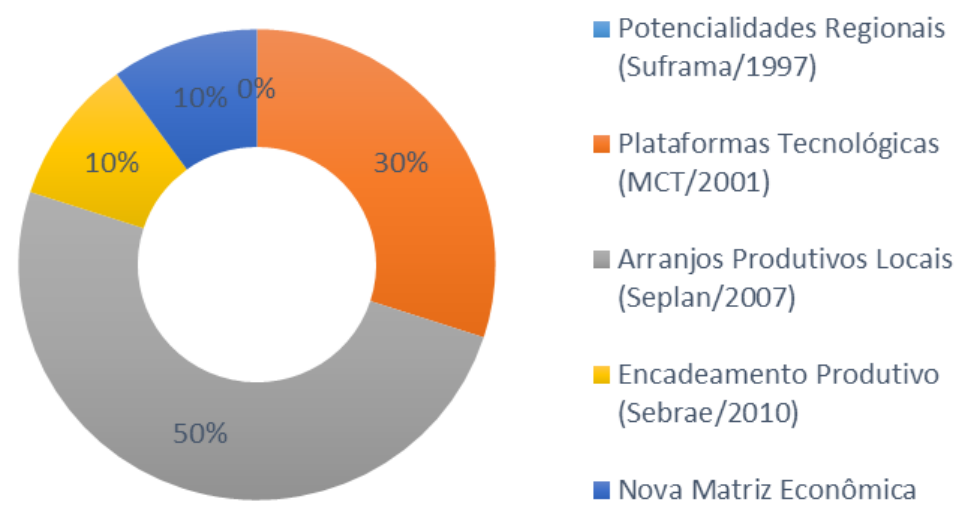

Gráfico 9 - Momento de inserção da empresa no instrumento APL Fonte: Dados da pesquisa.

Esse resultado confirma a participação de maior parte das empresas no modelo alvo, evidenciando que a estratégia foi eficiente na ação dos órgãos governamentais de inserir as empresas. De fato, Galdámez (2009) destaca que, na maioria dos casos, em um APL ocorre a participação de um número significativo de MPEs, por conta dos efeitos distributivos ou benéficos, em termos patrimoniais e emprego, às dimensões setorial e regional. 
Neste aspecto, Caporali e Volker (2004) afirmam que no desenvolvimento do APL, o planejamento participativo é o principal instrumento social e o agrupamento alarga esta participação dos atores, criando procedimentos de consulta social e intersetorial, o que garante a maior representatividade e produtividade das reuniões. Trata-se de uma ferramenta para a democratização e divulgação do arranjo como um todo, não se discutindo ações ou situações individuais de cada empresa e sim os objetivos, projetos, e problemas do setor como um todo e as ações para seu desenvolvimento.

\subsubsection{Mercado alvo da empresa (Inserção nos mercados nacional e internacional)}

Questionou-se qual mercado alvo em seus objetivos a empresa buscava ou ainda busca atingir com esta participação na estratégia governamental. A maior parte das empresas (60\%) respondeu que é o mercado regional e 40\% o nacional (Gráfico 10), não se registrando o internacional, o qual seria o alvo maior para aquelas empresas que desejam ampliar suas fronteiras de mercado.

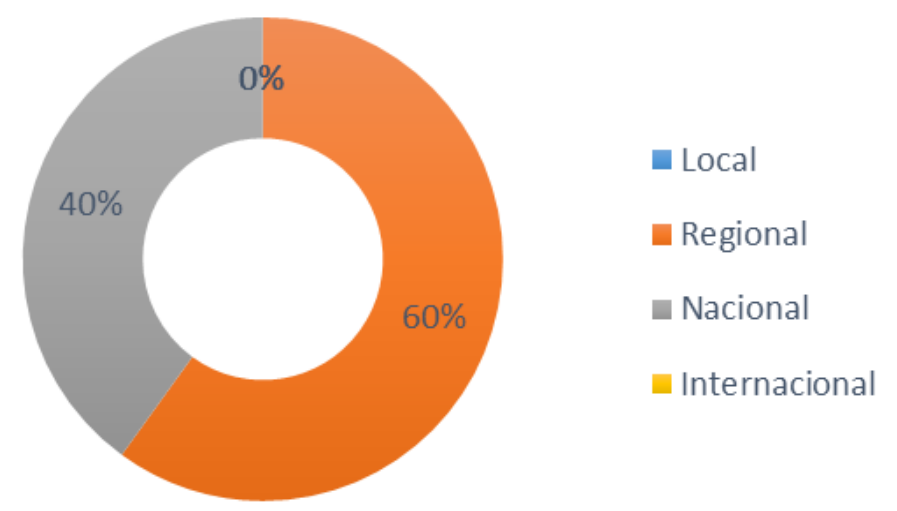

Gráfico 10 - Mercado alvo da empresa Fonte: Dados da pesquisa.

Sobre esta questão, Cardoso et al (2013) observa que a variável "Inserção nos Mercados Interno e Externo" do APL deve estar relacionada com a capacidade produtiva e mercadológica da organização, a fim de garantir condições de concorrência sustentáveis nos mercados interno e externo, podendo ser avaliada por meio do parâmetro "Mercado alvo da empresa", que serve para monitorar a evolução e a inserção das empresas de um APL nos respectivos nichos de mercados.

Neste aspecto, o aperfeiçoamento permanente do conhecimento do mercado, o mapeamento de novos canais de comercialização e de novos padrões de logística, o incremento de projetos de marketing, a participação em feiras e missões, torna-se fundamental para o fomento da produção qualificada e faz com que as empresas sejam impactadas e obtenham consideráveis ganhos (Suzigan et al, 2002). 
Em novos mercados, o APL consegue cumprir seu objetivo de crescimento, com geração de novos postos de trabalho e de renda. A inserção no mercado traz resultados concretos para os empresários, e é fundamental para que a mobilização empresarial ocorra, pois os empresários somente envolvem-se em projetos que possibilitem retornos financeiros. Portanto, essas ações de mercado devem ser pensadas e realizadas efetivamente, servindo de incentivo para todos os stakeholders.

\subsubsection{Existência de área específica na empresa para lidar com o tema APL (Desenvolvimento Tecnológico)}

Foi perguntado na quinta questão se existe na empresa área específica para lidar com o tema APL. A metade das empresas (50\%) respondeu 'P\&D ou C\&T' como área específica na empresa para lidar com o tema, seguida da área de 'Planejamento' com 40\%, conforme se visualiza no Gráfico 11.

Segundo Cardoso et al (2013), esta variável que está associada com a busca de vantagem competitiva sustentável por meio de pesquisas e estudos dos vínculos de cooperação entre a estrutura produtiva do APL e as instituições de P\&D, pode resultar no esforço de atualização tecnológica, que verifica o quanto as empresas investiram na aquisição de modernas máquinas e equipamentos e outras tecnologias.

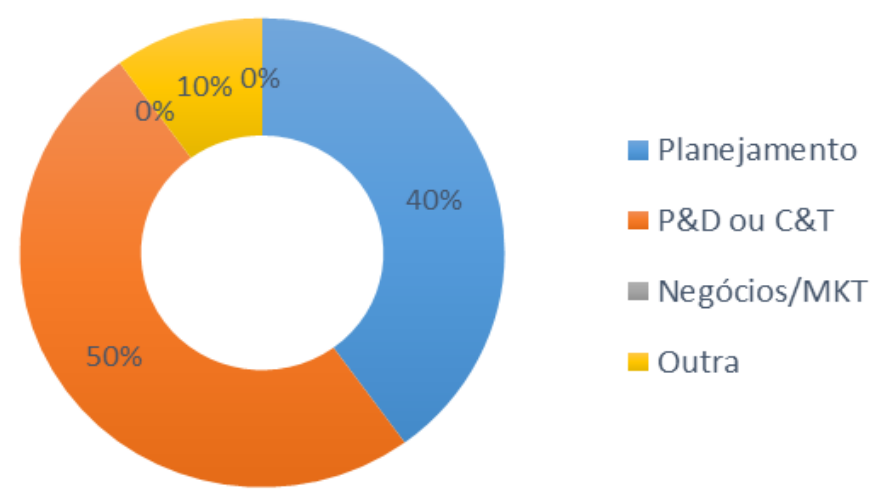

Gráfico 11 - Existência de área específica para lidar com APL Fonte: Dados da pesquisa.

Apesar das empresas entrevistadas responderem que possuem área específica relacionada a $\mathrm{P} \& \mathrm{D}$, percebe-se que este resultado não demonstra, de per si, a interpretação da variável atribuída, que são as atitudes práticas conjuntas com outras empresas do mesmo setor, em relação à força de trabalho e para a geração de renda e emprego. 


\subsubsection{GOVERNANÇA/PARCERIAS}

Esta análise avalia o papel da governança do arranjo como influência de desenvolvimento da empresa. Se esta é presente, suas ações podem contribuir para o aumento da eficiência coletiva, desenvolvimento de parcerias, confiança, cooperação, infraestrutura produtiva, interação entre os agentes e até capacitação dos membros. Para Mendonça (2008), se o relacionamento entre esta e a empresa apresenta restrições, o desenvolvimento pode ser inibido, ou se tornar egoísta, fugindo da proposta de APL, daí a necessidade de proceder à avaliação deste aspecto.

\subsubsection{Escolha sobre a área para desenvolver um projeto/parceria em APL (Especialização Produtiva)}

A sexta pergunta aos empreendedores procurou saber como se deu a escolha da área para desenvolver um projeto/parceria em APL, obtendo-se a resposta de que $30 \%$ foi por meio das 'discussões dos grupos formados para esse fim', $10 \%$ por 'encaminhamentos técnicos aos gestores' e 50\% por outra forma, no caso por ‘planejamento estratégico' (Gráfico 12).
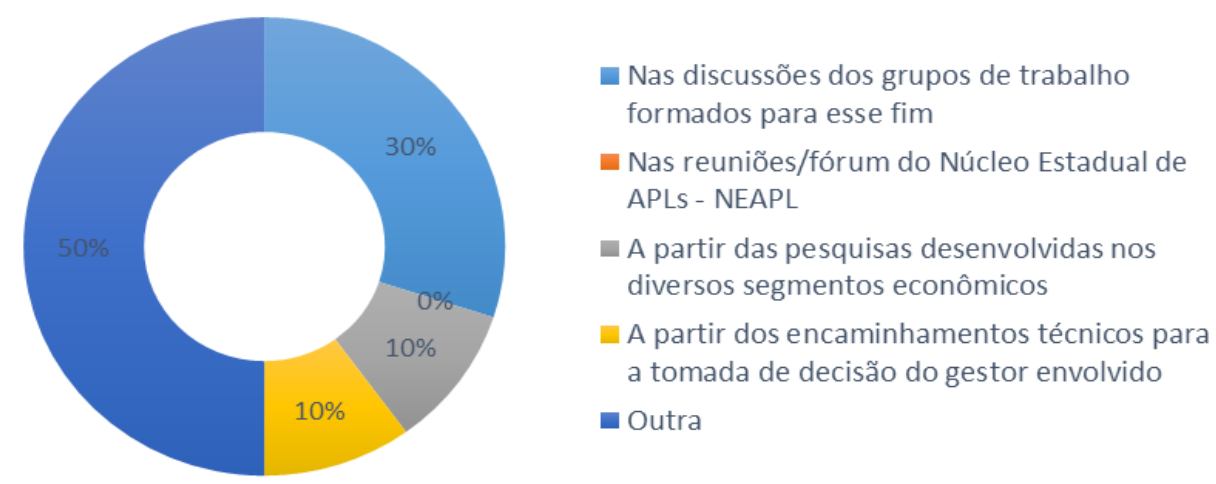

Gráfico 12 - Escolha sobre a área para desenvolver um projeto/parceria em APL Fonte: Dados da pesquisa.

Fica evidenciado neste resultado que as empresas, além de unidades produtivas de bens e serviços em si, possuem conhecimento em torno de uma atividade econômica principal e buscam o desenvolvimento de parcerias e interação entre os agentes, além de ter implícitas em seu conceito as atividades de cooperação e confiança, e a busca por infraestrutura produtiva disponibilizados pelos agentes fomentadores (Suzigan et al, 2002).

\subsubsection{Forma como empresas, governos e demais entidades apoiam o negócio (Estrutura de Governança)}

Indagou-se na sétima questão qual a maneira como empresas, governos e demais entidades apoiam o negócio. Cerca de um terço (30\%) respondeu 'na disponibilização direta ou 
indireta de infraestrutura, crédito e treinamento de mão de obra para a produção em eventuais necessidades', 20\% 'na aquisição de produtos, disponibilização direta ou indireta de infraestrutura...' e 50\% que 'não há nenhum tipo de apoio' (Gráfico 13).
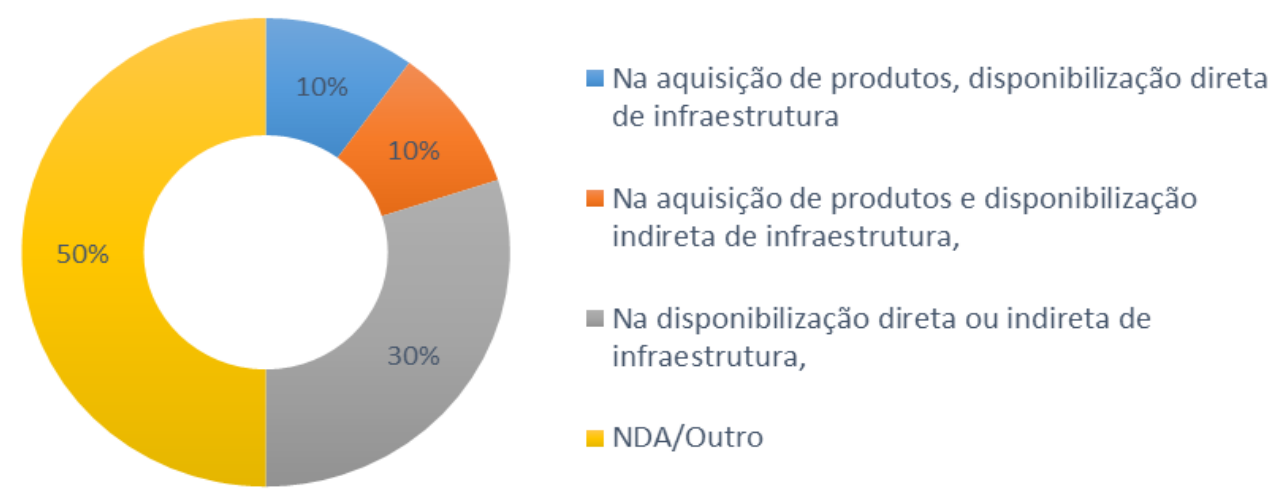

Gráfico 13 - Forma como empresas, governos e demais entidades apoiam o negócio Fonte: Dados da pesquisa.

O resultado indica que os canais (pessoas físicas ou organizações) capazes de coordenar e promover ações de negócios e processos decisórios entre os atores de um APL demandam ser revistos pela governança do cluster, no sentido de ampliar o percentual acima. De acordo com Ivo (2002), a disponibilidade do Estado em intervir nas relações sociais provoca um enorme aumento das demandas dirigidas às instituições políticas, determinando uma paralisia dos governos por sobrecargas de demandas, onde essas demandas geram tendências inflacionárias da economia.

Thury et al (2010), observa, porém, que a ausência de estruturas institucionais próprias de apoio aos empreendedores dificulta significativamente sua penetração mais ampla nos mercados competitivos, sua interlocução enquanto corpo coletivo com interesses econômicos delimitados e sua mobilização em favor da construção de soluções para problemas comuns do cluster.

\subsubsection{Relacionamento da empresa com as demais empresas do setor (Cooperação)}

Foi perguntado na oitava questão como se encontra o relacionamento da empresa com as demais do setor, obtendo-se como resposta que para 50\% 'não existe nenhum tipo de relacionamento entre sua empresa com as demais', 10\% 'é bom, com eventuais acordos de produção e compartilhamento de informações através da intervenção da governança do APL', $20 \%$ respondeu que 'é tenso devido à disputa por clientes, não há acordos e compartilhamento de informações somente com a intervenção da governança' e 10\% 'é muito bom (Gráfico 14). 

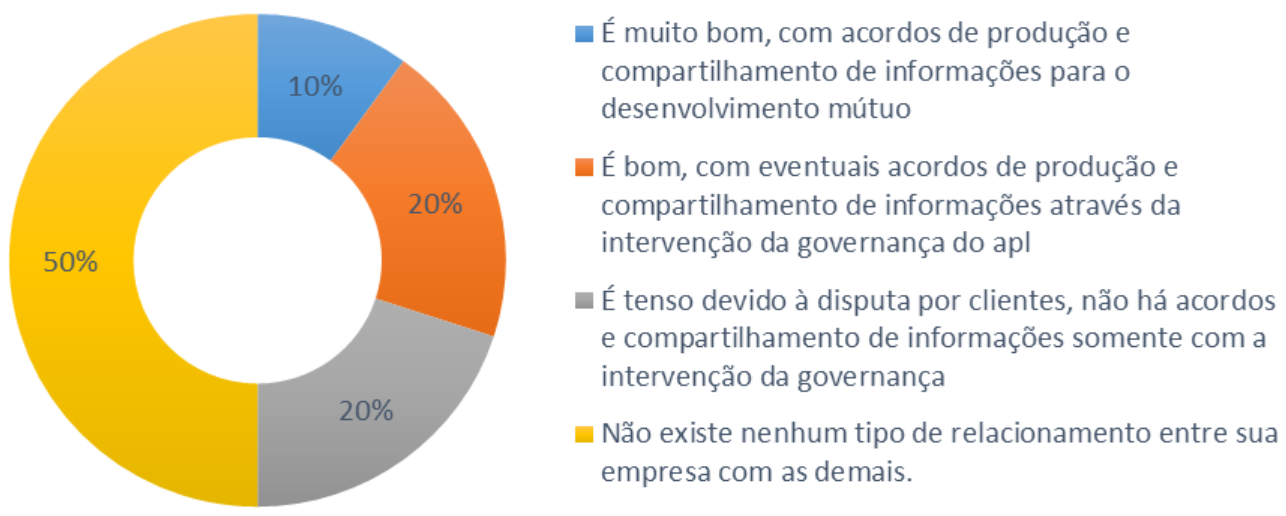

Gráfico 14 - Relacionamento da empresa com as demais empresas do setor Fonte: Dados da pesquisa.

$\mathrm{Na}$ análise de Oliveira et al (2010), a ‘cooperação' das empresas de um cluster deve ser avaliada a partir de uma variável que representa o envolvimento dos empreendedores em ações de cooperação integrada. $\mathrm{O}$ resultado da pesquisa apontou que as relações mantidas frente ao ambiente instável de negociação ao qual estão imersas, reforçam a premissa de ampliar os canais de cooperação entre as unidades produtivas, pois conforme observa Galdamez (2009), a cooperação é um instrumento que permite incorporar em rede, ciclos de inovação tecnológica e determina resultados do processo de um aglomerado de micro e pequenos empreendedores.

\subsubsection{Relacionamento empresa e governança do arranjo (Estrutura de Governança)}

Perguntou-se nesta nona questão como está o relacionamento entre empresa e governança do APL. Um terço das empresas (30\%) respondeu que existe 'bom relacionamento entre a empresa e a governança do APL, a empresa beneficia-se dos projetos, mas não participa do planejamento das atividades do arranjo' e para 50\% que 'a empresa não se relaciona com o arranjo'(Gráfico 15).
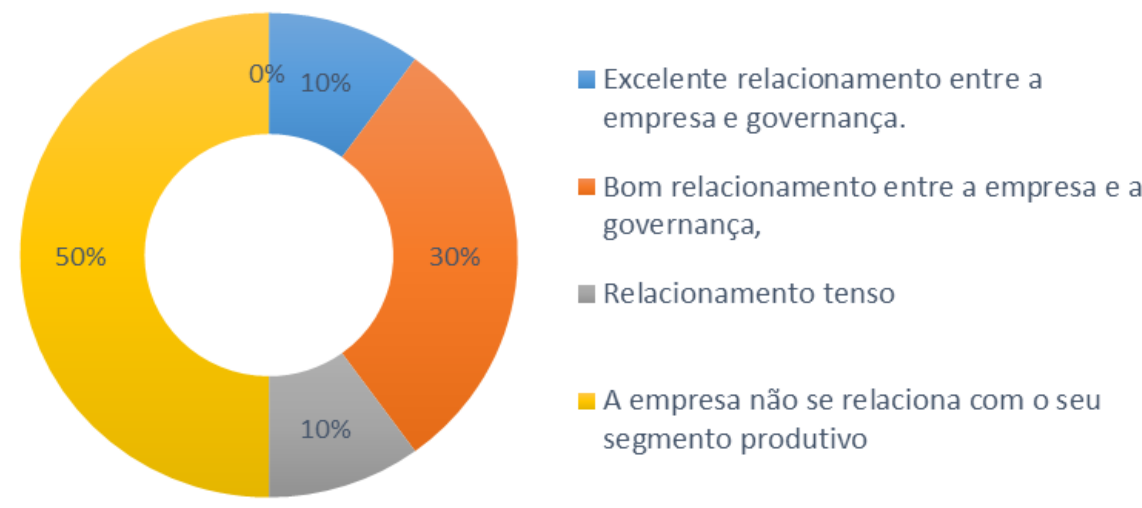

Gráfico 15 - Relacionamento entre a empresa e a governança do arranjo Fonte: Dados da pesquisa. 
Percebe-se que mais da metade das unidades produtivas reconhece nos canais, a capacidade de coordenar e promover ações de negócios e processos decisórios entre os atores de um APL, porém, boa parcela sequer se relaciona no arranjo. Takeda et al (2008) enfatiza a importância das características de cooperação, interdependência, confiança e eficiência coletiva, o que pode ser avaliado pela relação que se estabelece entre a empresa e as demais do mesmo setor, como acordos de produção e compartilhamento de informações, relação que acontece naturalmente nos APL mais desenvolvidos que têm servido de referência.

É na 'Estrutura de Governança' e sinergia de ações entre diferentes atores (questões do grupo 3.2.2), que reside um dos maiores desafios às ações de estruturação e fortalecimento deste APL: o descompasso entre a lógica das políticas e a responsabilidade socioeconômica e ambiental representadas por atores diversos, desde os institucionais (SEPLANCTI, SUFRAMA, entre outros) até os beneficiários (associações de produtores, entre outros), implicando em falta de sinergia interinstitucional.

\subsubsection{FORNECEDORES}

Os fornecedores incluem-se como agentes do arranjo involuntariamente, por terem grande responsabilidade no processo que existe dentro dele. É com eles que se estabelecem as relações de interdependência, e, em um arranjo bem estruturado, torna-se um dos agentes responsáveis pela eficiência coletiva, o que o torna como um dos mais importantes participantes. Porém, o não comprometimento do fornecedor com a empresa, seja pela qualidade dos seus produtos ou pela prestação de seus serviços, pode retardar o desenvolvimento da empresa, tornando-se um empecilho. Por este motivo, foi incluído no diagnóstico a avaliação da participação dos fornecedores nas atividades do cluster. Esta questão estimula as empresas a reverem suas políticas de contratação de fornecedores e suas relações com eles.

\subsubsection{Aquisição da matéria prima para o(s) produto(s) da empresa (Eficiência Coletiva)}

Dois resultados chamam a atenção nesta décima questão. Um deles, com $30 \%$, foi que a aquisição de matéria prima vem 'de cooperativas e/ou associações do interior do Amazonas' e a outra, também com 30\%, que vem “direto de produtores individuais do interior do Amazonas' e as demais somaram 40\% (Gráfico 16). 


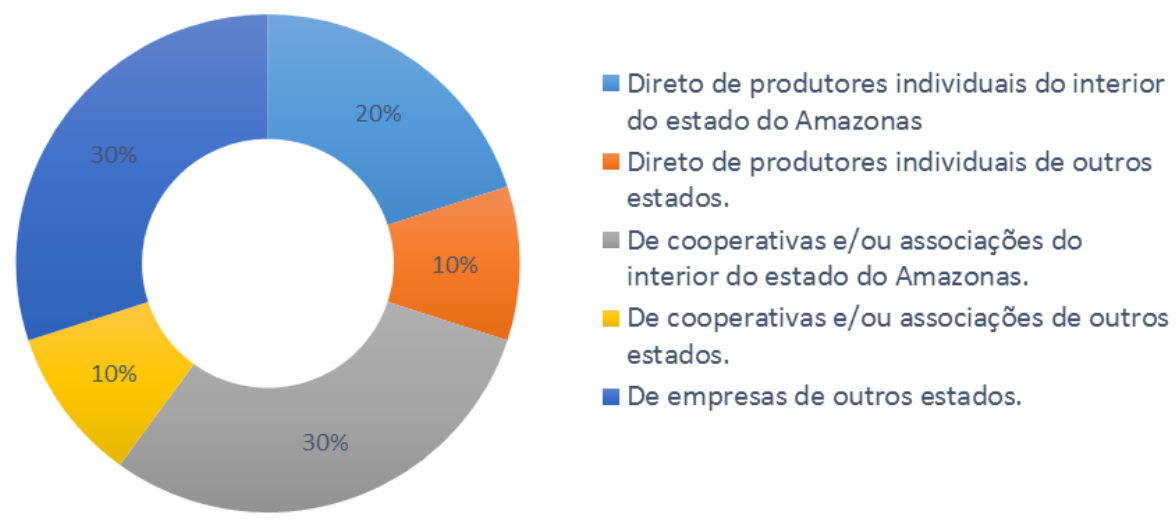

Gráfico 16 - Aquisição da matéria prima para o(s) produto(s) da empresa Fonte: Dados da pesquisa.

Segundo Lastres et al (2003), existem ações sem compromisso com o adensamento e enraizamento das atividades no local e que acabam por estimular as empresas a comprar fora de seus arranjos e regiões. Tal tipo de apoio pode provocar a desarticulação da produção local/regional, o que é particularmente grave nas áreas menos desenvolvidas, reforçando a fragmentação produtiva e as desigualdades regionais, econômicas e sociais.

\subsubsection{Participação dos fornecedores no desenvolvimento dos negócios (Eficiência}

\section{Coletiva)}

Nesta décima primeira questão, 60\% das empresas responderam que os fornecedores 'apresentam eventuais falhas em assumir seus compromissos com a empresa, dificultando o desempenho, e não têm participação nos negócios', 20\% que 'assumem seus compromissos de fornecimento de insumos, porém não tem participação nos negócios' e $20 \%$ que 'os fornecedores bloqueiam o desenvolvimento da empresa' (Gráfico 17).
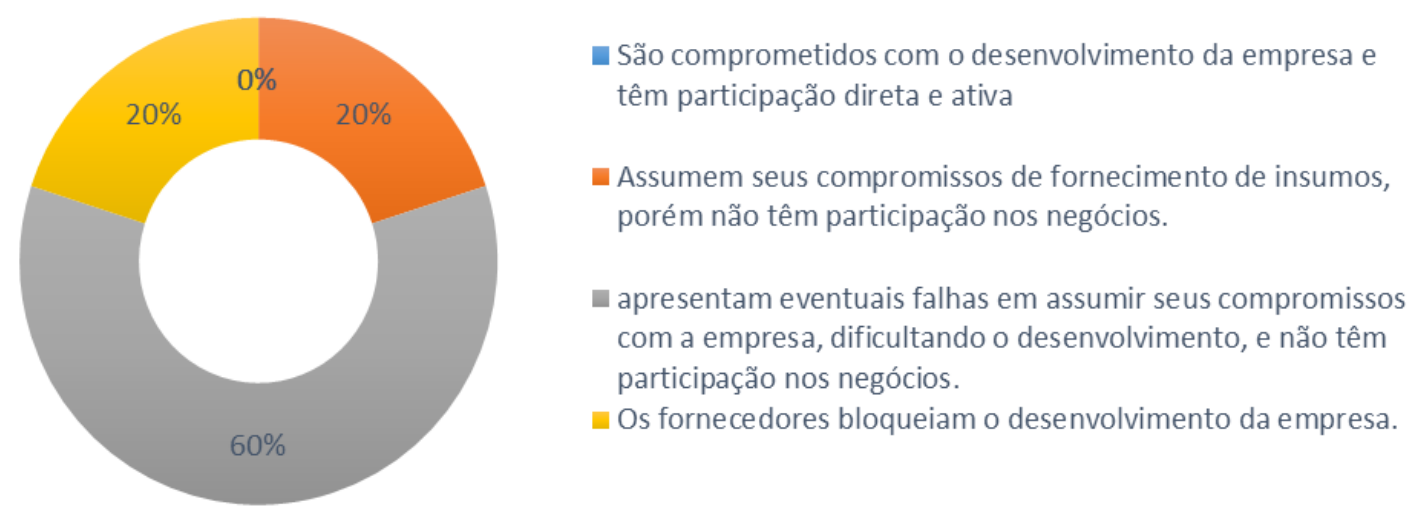

Gráfico 17 - Participação dos fornecedores no desenvolvimento dos negócios Fonte: Dados da pesquisa.

Trata-se de um resultado pouco favorável para um indicador de eficiência coletiva, na medida em que a falta de maior envolvimento e compromisso pode impactar negativamente o encadeamento produtivo, evitando que maiores benefícios sejam alcançados a partir do 
conceito de eficiência coletiva como vantagem competitiva derivada de economias externas locais e das ações conjuntas, conforme aborda Oliveira et al (2010).

\subsubsection{ACESSO AO MERCADO}

Este grupo de questões relaciona-se com as ações de desenvolvimento da tecnologia, melhoria dos processos, planejamento e capacitação. A questão levantada sobre este aspecto é feita sob a ótica de um APL que considera a competitividade gerada pela inovação como uma característica fundamental que possa retratar sua maturidade.

\subsubsection{Qualificação para acesso ao mercado (Capacidade de Competição)}

Nesta décima segunda questão registrou-se que $20 \%$ foi por 'Sistema S' (SEBRAE/Am, SENAI, SENAC) e 10\% 'FIEAM' (IEL), totalizando 30\%, o que ficou muito aquém dos $70 \%$ das entrevistadas que assinalou nenhuma das instituições indicadas (Gráfico 18).

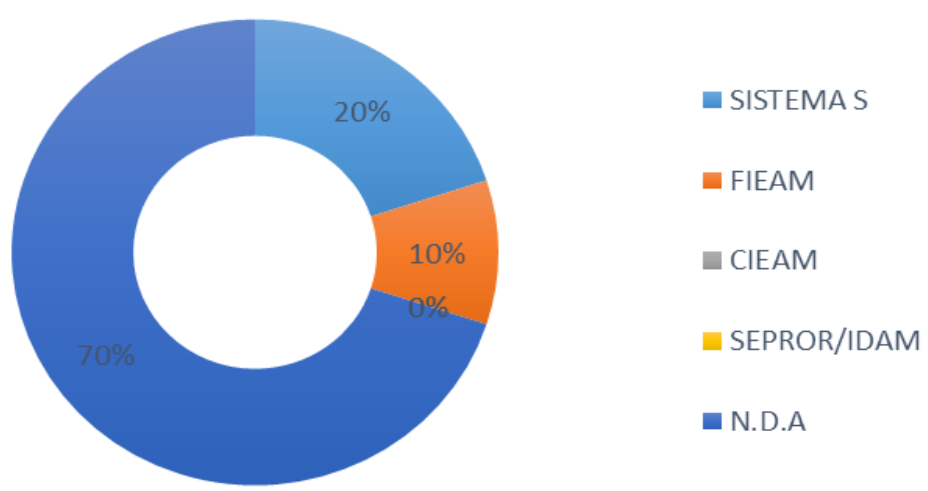

Gráfico 18 - Qualificação para acesso ao mercado Fonte: Dados da pesquisa.

Para Oliveira et al (2010), a variável capacidade de competição está relacionada com a forma com que o APL consegue competir por meio de inovação organizacional e tecnológica envolvendo produtos e processos, podendo revelar o quanto do faturamento está sendo empregado em estudos e desenvolvimento de produtos, em razão de quanto maior este indicador, maior a capacidade de competição do APL. Assim, é preciso rever as instituições e os cursos de qualificação oferecidos a este APL.

\subsubsection{Aumento percentual no nível de produtividade (Avaliação e Medição do}

\section{Desempenho)}

Metade das empresas registrou que houve aumento de até $10 \%$ da produtividade neste quesito; um terço respondeu até $20 \%$ e as demais responderam que não ocorreu aumento percentual (Gráfico 19), o que serve de substrato para o indicador que examina o aumento da quantidade e qualidade dos produtos produzidos. 


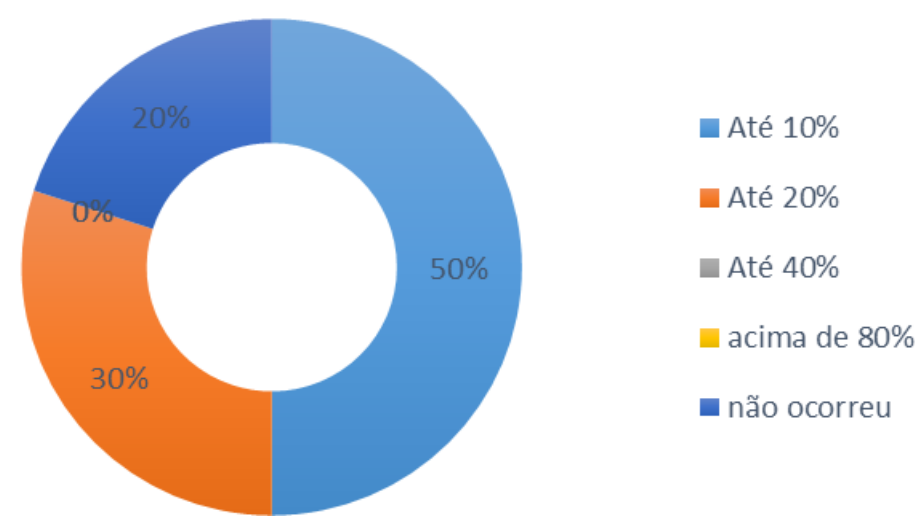

Gráfico 19 - Aumento percentual no nível de produtividade Fonte: Dados da pesquisa.

Por amostragem, tem-se um resultado significativo para um dos principais indicadores de avaliação e medição do desempenho, onde os dados foram coletados, tabulados e analisados tecnicamente. É uma avaliação de desempenho que precisa ser integrada com o atendimento ou ações de melhoria contínua que podem ser implantadas no APL conforme defende Oliveira et al (2010), conduzindo a uma melhor qualidade do produto final, considerando que produtividade e qualidade andam juntas.

\subsubsection{Visibilidade da empresa pelo mercado e sociedade (Trajetória Evolutiva)}

Neste décimo quarto quesito, a maioria das empresas (60\%) respondeu que 'são bem vistas pelo crescimento econômico, qualidade dos produtos e atividades em prol do Desenvolvimento Regional Sustentável - DRS'; 10\% respondeu igual, apenas com a diferença de que não apresenta atividades em prol do DRS (Gráfico 20).
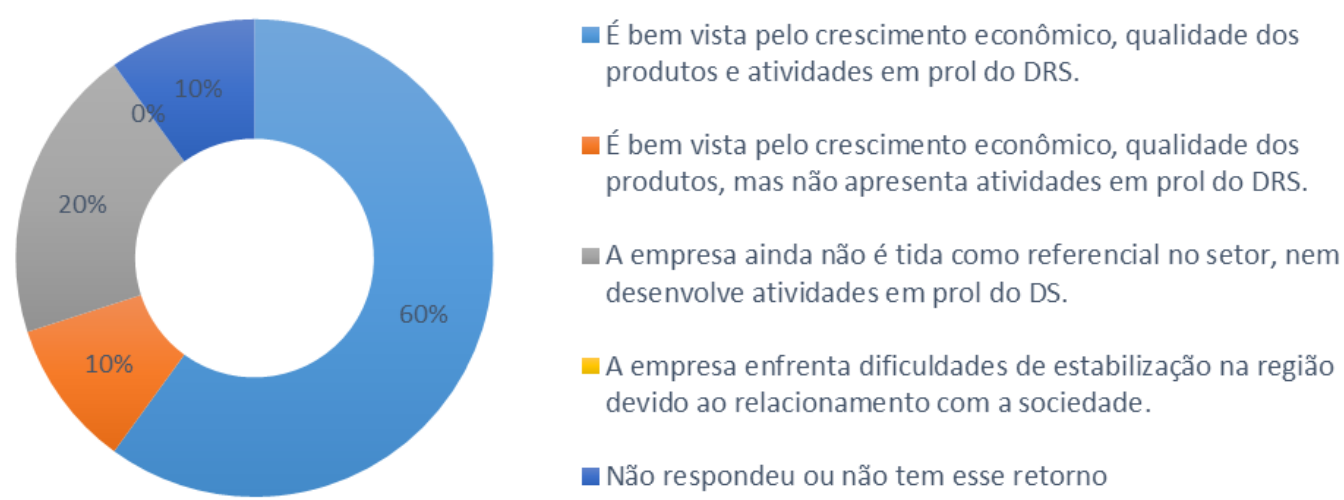

Gráfico 20 - Visibilidade da empresa pelo mercado e sociedade em geral Fonte: Dados da pesquisa.

A soma destes dois resultados torna possível visualizar a trajetória evolutiva do cluster, indicador de evolução da produção, qualidade e de comercialização. De fato, Mendonça (2008), considera a variável "Trajetória Evolutiva" correlacionada com a evolução da produção e de comercialização de um APL, podendo ser analisada também por meio de Valor Adicionado à 
Produção, visto que quanto maior o resultado, maior o valor adicionado à produção nas atividades desenvolvidas pelas empresas.

\subsubsection{METODOLOGIA ORGANIZACIONAL E TECNOLOGIAS}

Este grupo reúne as características relacionadas a padronização dos processos, que leva à maior produtividade, planejamento estratégico, englobando as estratégias de melhoria contínua, que se relacionam à qualidade e se refletem na busca por certificação, e o controle de processos. Todas estas características representam ações fundamentais para o desenvolvimento de qualquer empresa, e a levam a obter diferenciais primeiramente de produção, mas que resultam em inovação. Este tipo de prática na empresa é essencial para o seu desenvolvimento.

\subsubsection{Modelo organizacional utilizado na empresa segundo o projeto apresentado para a} Subvenção para medir seu desempenho (Avaliação e Medição do Desempenho)

Nesta décima quinta questão, uma boa parcela das empresas (50\%) respondeu 'PDCA' e $20 \%$ delas responderam 'SWOT/FOFA', ou seja, configura-se uma maioria (70\%) utilizando algum tipo de metodologia de melhoria do desempenho (Gráfico 21).

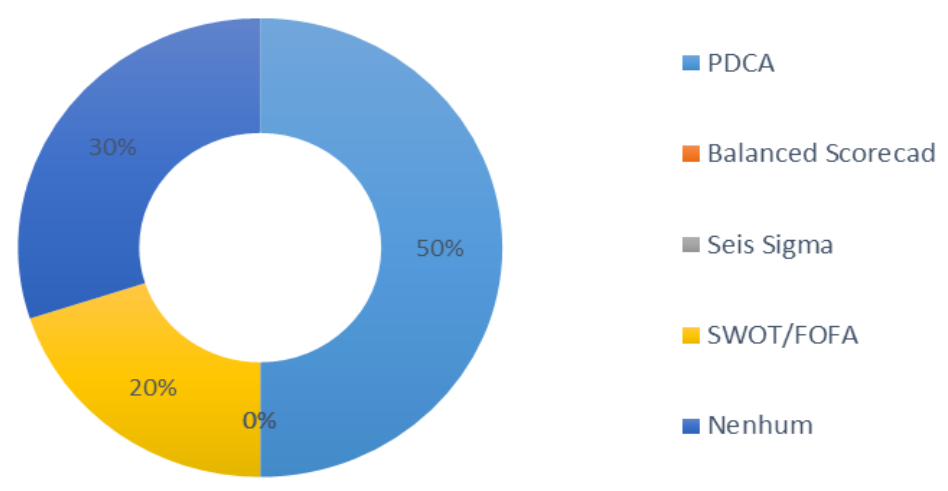

Gráfico 21 - Modelo organizacional utilizado na empresa Fonte: Dados da pesquisa.

Esta questão se inclui no exame do modelo utilizado para o aumento da quantidade e qualidade dos produtos produzidos (Oliveira et al, 2010), indicador aplicado também no quesito 3.2.4.2, como avaliação e medição do desempenho. Por amostragem, tem-se um resultado promissor na avaliação e medição do desempenho, posto que se evidencia o uso de metodologias organizacionais e tecnologias.

\subsubsection{Informatização dos processos administrativos (Tecnologia da Informação)}

Um terço das empresas (30\%) respondeu nesta questão que 'todos informatizados, softwares específicos às necessidades e uso da internet', enquanto $40 \%$ assinalaram que 'somente os gerenciais informatizados, com ferramentas básicas e uso da internet' (Gráfico 22). 

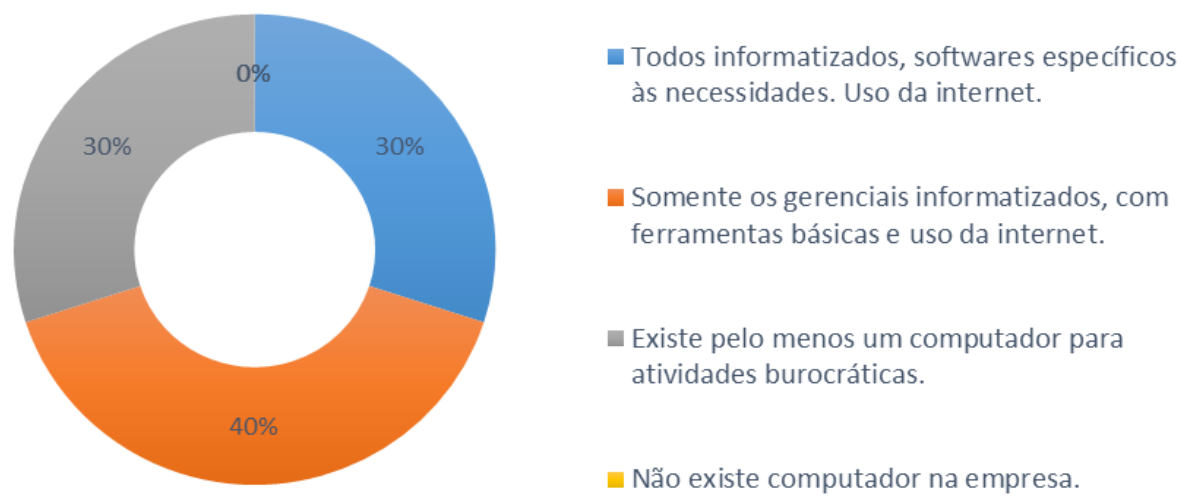

Gráfico 22 - Informatização dos processos administrativos

Fonte: Dados da pesquisa.

Neste quesito buscou-se analisar o indicador Tecnologia da Informação, que representa o grau de utilização desta variável na empresa. Percebe-se aqui um resultado promissor para o cluster neste indicador, considerando que a cooperação empresarial, segundo Lastres e Cassiolato (2003), pode ocorrer por meio de um intercâmbio sistemático de informações produtivas, tecnológicas e mercadológicas (com clientes, fornecedores, concorrentes e outros); interação de vários tipos, envolvendo empresas e outras organizações, por meio de programas comuns de treinamento, realização de eventos/feiras, cursos e seminários, entre outros; e pela integração de competências, por meio da realização de projetos conjuntos, incluindo desde melhoria de produtos e processos até desenvolvimento e pesquisa propriamente dita, entre empresas e destas com outras organizações.

\subsubsection{Tecnologia de produção implantada na Empresa (Especialização produtiva)}

$\mathrm{O}$ resultado neste questionamento foi que em sua maioria (70\%), as empresas responderam que 'a produção é dividida em processos semiautomáticos e manuais', ficando as demais respostas com 10\% cada, como se pode visualizar no Gráfico 23.
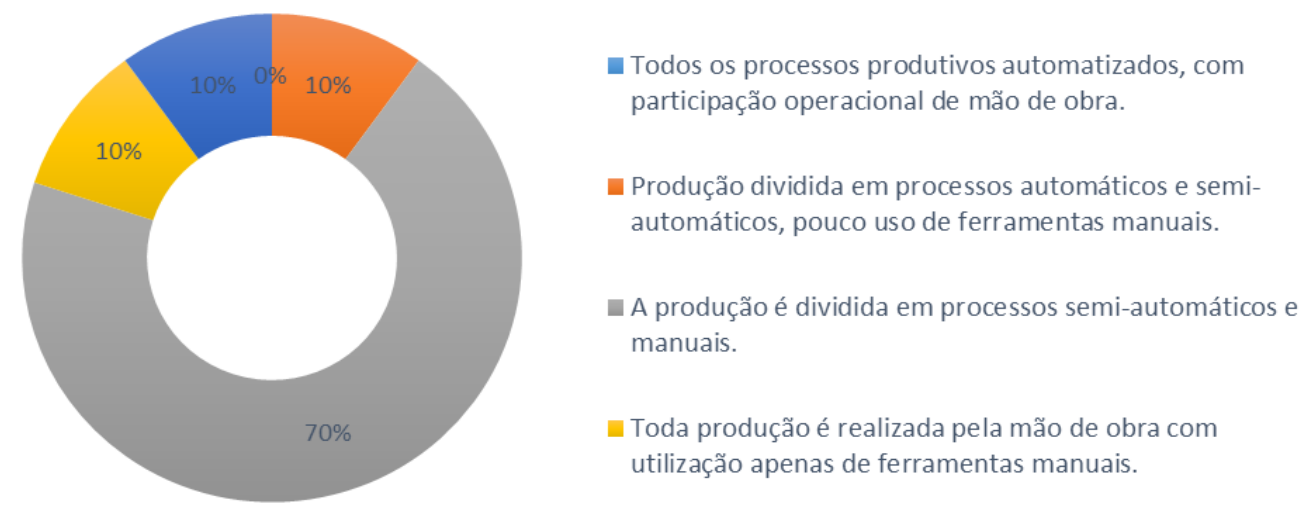

Gráfico 23 - Tecnologia de produção implantada na empresa

Fonte: Dados da pesquisa. 
O quesito tecnologia refere-se ao tipo de tecnologia utilizada na empresa para o desenvolvimento de suas atividades tanto de produção quanto administrativas. A característica desenvolvimento de tecnologia é um fator de grande importância para as empresas e o arranjo, pelo fato de proporcionar maior eficiência nos processos e o aumento da produtividade, o que leva a empresa a buscar estratégias de estímulo às vendas. A tecnologia também permite à empresa desenvolver novos produtos, diferenciados, que possam alcançar novos mercados. Quanto mais a empresa estiver evoluída neste aspecto, maior serão suas chances de desenvolvimento no setor.

Para o indicador Especialização Produtiva, percebe-se um resultado significativo, pois, compreende a participação das unidades de produção, no conhecimento tácito ou explícito em torno de uma atividade econômica principal, a partir da internalização ${ }^{30}$ dos processos produtivos. Britto e Albuquerque (2002), endossam que a variável "Especialização Produtiva" é muito pertinente, pois além da produção de bens e serviços em si, envolve conhecimento, tácito ou explícito, que as pessoas e organizações de um território possuem em torno de uma atividade econômica principal, pautando-se na quantidade locacional (QL) que identifica a especialização produtiva local e permite configurar a microrregião como um APL, já que APLs que possuírem QL > 1 e participação relativa maior que 1\%, resultam em critério de densidade.

\subsubsection{CRÉDITO E FINANCIAMENTO}

Este grupo envolve a participação dos agentes de fomento do arranjo nas atividades da empresa, e pode ser avaliado pela contribuição que cada um deles presta a ela, seja diretamente, beneficiando o conjunto, o que para o arranjo seria o ideal, ou diretamente, incentivando suas atividades individuais. A questão que se estabelece sobre este fator é sobre a forma de influência dos parceiros nas atividades da empresa. Se vai impactar positivamente, estabelecese a relação de cooperação e confiança entre eles, e, dependendo do tipo de apoio disponibilizado, não somente por créditos, mas, também, por infraestrutura ou capacitação, tanto a empresa quanto o arranjo passam a ter maiores chances de se desenvolver.

Barbosa (2015) afirma que programas de subvenção geralmente têm alta dependência financeira dos governos federais e estaduais, freqüentemente interrompido devido a mudanças nas políticas governamentais. O sucesso de um programa de prospecção e conservação, por exemplo, dependerá da capacidade de encontrar mecanismos de financiamento de longo prazo.

\footnotetext{
${ }^{30}$ Incorporação dos conhecimentos conhecimentos explícitos em sob a forma de novos modelos mentais ou conhecimento técnico compartilhado. É a volta do explícito para o tácito, entendida como apropriação do conhecimento explícito por um indivíduo, e seu enquadramento (sua compreensão) dentro dos modelos mentais particulares deste indivíduo (ALVES, 2015).
} 
Uma maneira de fazer isso é buscar diferentes fontes de financiamento. A diversificação das fontes é importante para isolar e proteger o programa e as instituições envolvidas de outros interesses que, muitas vezes, ultrapassam os programas financiados em projectos nacionais e internacionais.

\subsubsection{Participação no programa da FAPEAM de Subvenção aos APLS do Amazonas} (Capital Social)

A pesquisa confirmou nesta questão que 8 (oito) empresas participaram do PAPPE/FAPEAM de Subvenção aos APLS do Amazonas, no Edital 07/2004 (40\%) e 08/2008 (40\%). Dentre estas, uma assinalou também a participação na Edição 017/2008 (Gráfico 24).

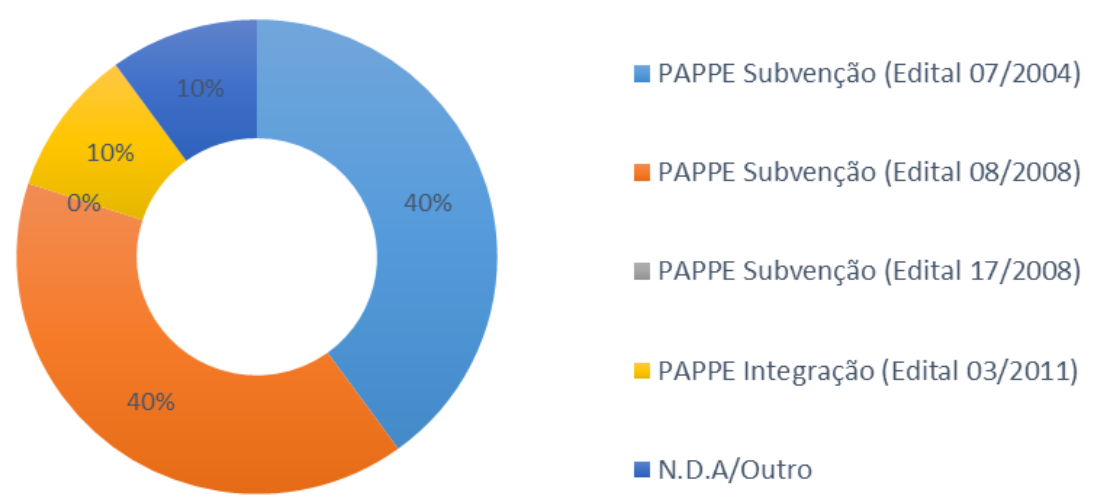

Gráfico 24 - Participação no PAPPE/FAPEAM de Subvenção aos APLS do AM. Fonte: Dados da pesquisa.

Considerando que este quesito envolve o exame do aumento do número de participantes em ações de fomento à formação de capital, percebe-se um baixo índice da participação do APL estudado em programas de alavancagem. Apenas uma unidade produtiva participou de mais de uma edição.

Thury et al (2010) já havia constatado na primeira fase dos APLs a predominância de recursos públicos, em especial federais e estaduais, nas ações dos PDPs. O ponto crítico principal é a pequena participação de recursos privados. Oliveira et al (2010) questiona o compromisso dos entes privados envolvidos, pois o risco de empreendimento, inerente à inversão capitalista, pouco aparece ou transparece nesse contexto.

\subsubsection{Obtenção de créditos/financiamentos complementares (Capital Social)}

A quase totalidade (80\%) das entrevistadas neste quesito, respondeu que não acessou nenhuma linha de crédito (Gráfico 25). O raciocínio aqui, segue a mesma linha do indicador de alavancagem do capital social, ou seja, baixo índice de participação do APL. É possível deduzir 
que a oferta de serviços não tenha se apresentado de forma atrativa para as empresas do segmento em estudo.

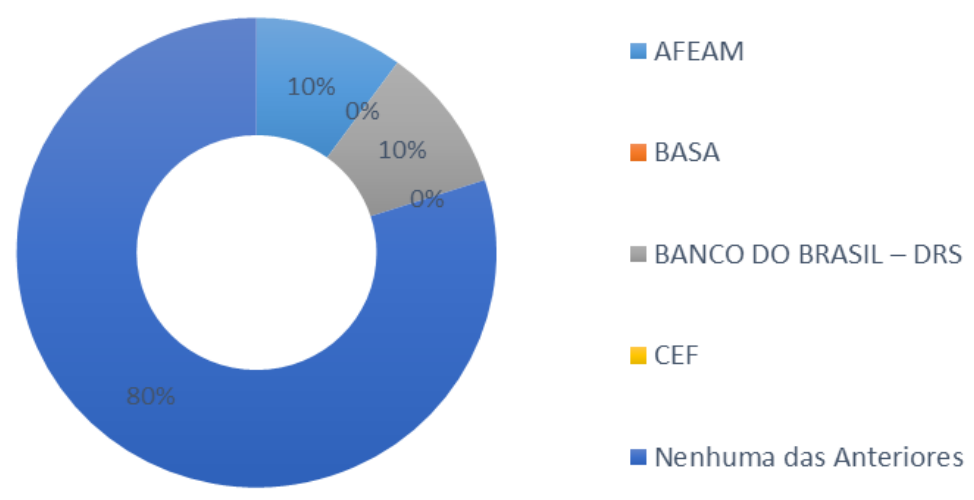

Gráfico 25 - Obtenção de créditos/financiamentos complementares Fonte: Dados da pesquisa.

Há necessidade de as firmas superarem restrições orçamentárias para aplicarem recursos próprios $\mathrm{P} \& \mathrm{D}$ ou em parceria com outra instituição conforme recomenda Thury et al (2010). Ao se observar os gastos de $\mathrm{P} \& \mathrm{D}$ das indústrias farmacêuticas e de cosméticos multinacionais, constata-se a magnitude do desafio para o APL. Embora BB e BASA sejam citados nos PDPs, a AFEAM tem exercido papel de relevo na concessão de empréstimos com recursos do FTI.

\subsubsection{CAPITAL SOCIAL}

Ao avaliar os clusters e seus interesses de interação, a importância de se levar em conta o capital social é vital, levando em conta que as questões sociais influenciam na dinâmica econômica. Afirmar que o comportamento humano está politicamente imerso, significa dizer que é moldado na luta pelo poder envolvendo atores, como o estado e classes sociais.

Neste contexto, Barbosa (2015) considera vital a modernização e a reorientação da estrutura produtiva hoje predominante, especialmente no setor industrial, tornando ao mesmo tempo competitiva e melhor internalizadora de seus benefícios, pela criação de novos setores da economia, principalmente com base em ciência e tecnologia amistosas com o meio ambiente e capaz de utilizar amplamente os recursos naturais regionais. Acrescenta que é preciso promover a criação de emprego e ajudar a aumentar o nível de vida das populações da região, envolvendo as comunidades locais como parceiras efetivas dos resultados.

\subsubsection{Geração de emprego e renda propiciado pelo instrumento APL (Tecido Social)}

Nesta vigésima questão, a maior parte das empresas entrevistadas assinalou uma quantidade específica de geração de emprego, perfazendo um total de $80 \%$, conforme se visualiza no Gráfico 26. Apenas duas empresas (20\%) não informaram. 


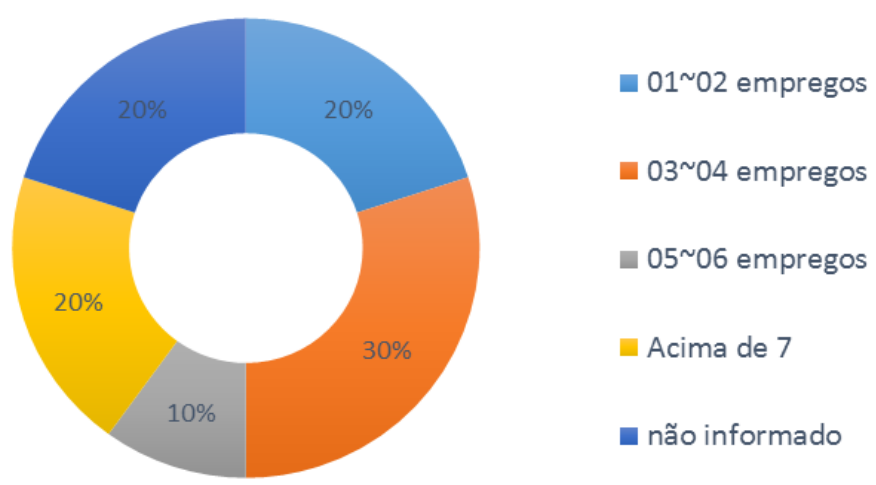

Gráfico 26 - Geração de emprego e renda propiciado no instrumento APL Fonte: Dados da pesquisa.

Considerando que a média de empregos em uma MPE é de 3 4, tem-se um resultado pouco expressivo para o indicador tecido social, dentro do capital social como fator determinante para o desenvolvimento econômico, já que a variável "Geração de Emprego e Renda", segundo Cardoso et al (2013), está ligada à participação das unidades produtivas, por meio de atitudes e práticas conjuntas, em relação à força de trabalho no aumento do emprego e da renda.

\subsubsection{Famílias beneficiadas com projeto apresentado à Subvenção (Tecido Social)}

Neste vigésimo primeiro quesito, 60\% das empresas responderam 'entre 20 e 50 famílias beneficiadas', $10 \%$ 'entre 50 e 100 famílias beneficiadas' e os $30 \%$ restantes não informaram (Gráfico 27).
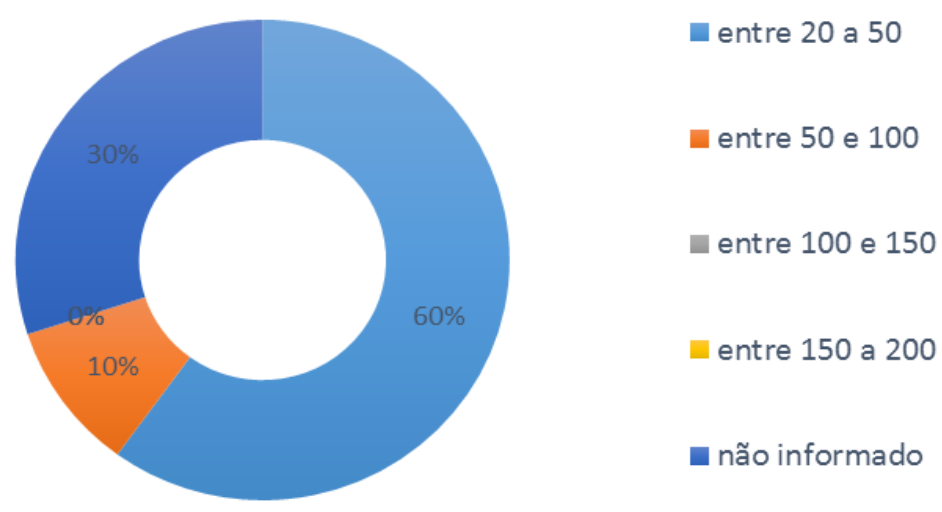

Gráfico 27 - Famílias beneficiadas com o projeto apresentado à Subvenção Fonte: Dados da pesquisa.

Considerando-se que metade das entrevistadas respondeu positivamente, tem-se um resultado que precisa melhorar em termos de tecido social, para o modelo alvo de desenvolvimento sustentável e regional APLs, considerando que a média de empregos vista na questão anterior foi considerada baixa.

O resultado deve levar a uma relevância do emprego e renda para as famílias, conforme Cardoso et al (2013), que identifica a relevância das atividades do APL em termos geração de 
emprego para o(s) município(s) de localização do arranjo, pois quanto maior o resultado nesta variável, melhor a posição do APL quanto à responsabilidade social, com geração de postos de trabalho e, consequentemente, melhor qualidade de vida para o ambiente humano e natural.

\subsubsection{Relações interpessoais constituídas na empresa (Tecido Social)}

A maior parte das empresas (60\%) respondeu nesta questão que é 'excelente, com colaboradores sempre motivados que participam das decisões'; 20\% responderam 'bom, colaboradores comprometidos, mas não participam das decisões a menos que convidados'; $10 \%$ que é ‘difícil, os colaboradores não são comprometidos com o trabalho' (Gráfico 28).

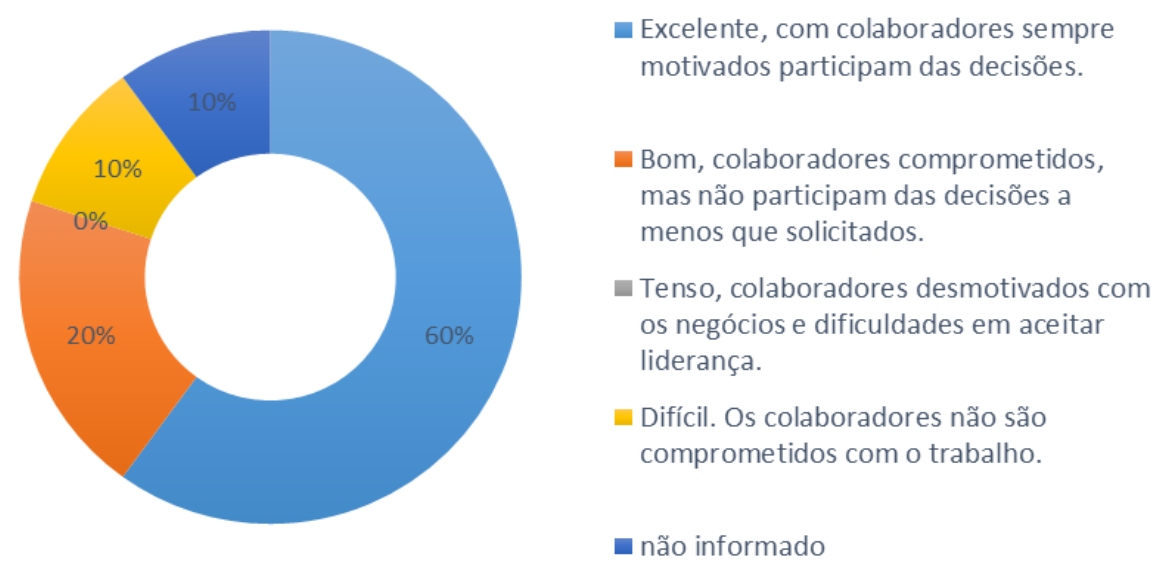

Gráfico 28 - Relações interpessoais constituídas na empresa Fonte: Dados da pesquisa.

Este resultado segue a linha de raciocínio similar ao da resposta no quesito 20, quer dizer, é um resultado que pode melhorar, pois trata-se de uma atividade que, conforme Galdámez (2009), ajuda a reposicionar as ações de melhoria contínua a partir de um projeto formal dentro de uma visão de modelo de gestão de desempenho.

Sobre esta questão é necessário avaliar a influência da liderança na vida dos colaboradores e a participação destes nas decisões da empresa. Na questão estabelecida, deve ser retratada segundo Mendonça (2008), a liderança participativa como ideal para o desenvolvimento da empresa, por se tratar de uma característica que resulta em cooperação e confiança interna, que refletirá no conjunto.

\subsubsection{CAPACITAÇÃO TECNOLÓGICA}

Este grupo de questões refere-se às atividades de capacitação dos membros e liderança da empresa e a busca por aperfeiçoamento, consideradas como características fundamentais no desenvolvimento das empresas e dos APL. Esta questão permite a visualização do nível de conhecimento dos colaboradores e gerentes (direção), e faz a empresa refletir sobre a necessidade da busca por novos conhecimentos. 


\subsubsection{Capacitação dos recursos humanos (Capacitação Tecnológica)}

Neste quesito, 30\% responderam 'UEA' e 20\% 'UFAM', perfazendo a metade das empresas, enquanto a outra metade (50\%) respondeu 'nenhuma das alternativas', demonstrando que não houve ‘capacitação dos recursos humanos’ nas instituições indicadas (Gráfico 29).

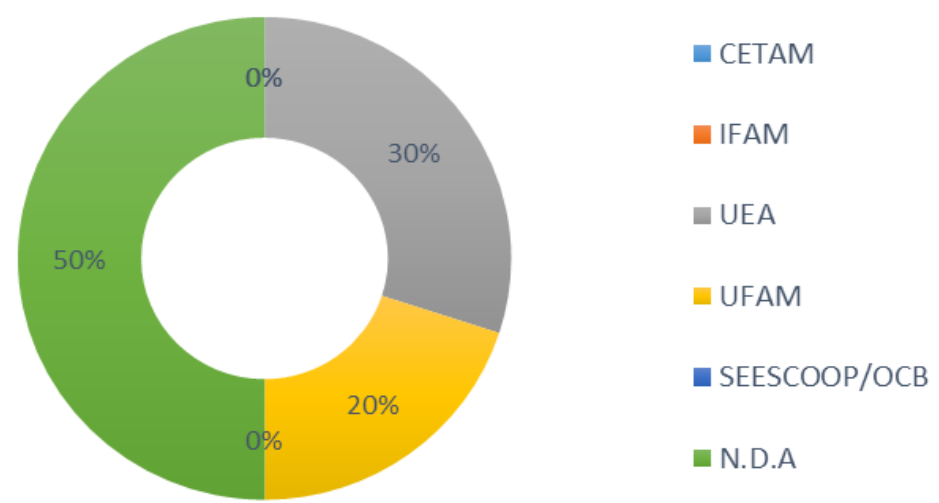

Gráfico 29 - Capacitação dos recursos humanos

Fonte: Dados da pesquisa.

Segundo alguns autores este indicador refere-se ao processo de criação, absorção e socialização ${ }^{31}$ de novos conhecimentos traduzidos em produtos (Crocco et al, 2003 e Mendonça, 2008). O resultado é bastante preocupante para a governança do APL, pois pode significar que as ofertas de capacitação tecnológica das instituições citadas não atenderam ao interesse das empresas. O mesmo resultado foi observado quanto ao quesito qualificação. Para Thury et al (2010) a questão tecnológico-inovativa está no cerne de certos APLs, como o de Fitoterápicos e Fitocosméticos, que utiliza intensivamente processos biotecnológicos.

Para Alves (2015) a aprendizagem organizacional e sua externalização, por meio do conhecimento, são antecedentes da inovação. O pressuposto básico é que a aprendizagem desempenha papel fundamental para permitir que empresas atinjam a velocidade e flexibilidade no âmbito do processo de inovativo, e a capacidade de absorção de conhecimento da organização depende dos indivíduos que estão situados na interface com outras organizações.

\subsubsection{Nível de conhecimento técnico dos colaboradores (Capacitação Tecnológica)}

Sete empresas $(70 \%)$ responderam nesta penúltima questão que seus colaboradores 'Assimilaram bem as técnicas e há pelo menos 1 (um) treinamento/ano. Normalmente aplicam as práticas e inovam'; uma empresa (10\%) que 'Assimila bem as técnicas e há treinamentos todo ano. Aplicam conhecimentos e inovam' e uma não informou (Gráfico 30). O resultado geral neste quesito se apresenta bem promissor.

\footnotetext{
${ }^{31}$ Processo em que os participantes adquirem habilidades, conhecimentos e/ou avaliam novas tecnologias uns com os outros. Pode ser entendido como compartilhamento de experiências. O dilema da socialização é integrar os diferentes recursos de conhecimento para utilizar a nova tecnologia (ALVES, 2015).
} 


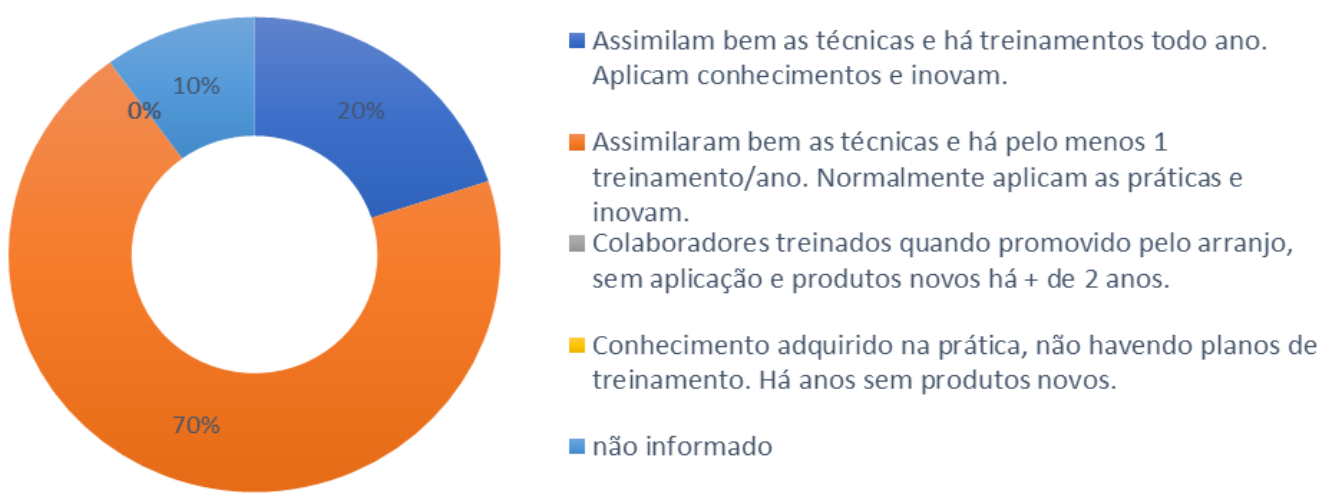

Gráfico 30 - Nível de conhecimento técnico adquirido pelos colaboradores Fonte: Dados da pesquisa.

\subsubsection{Nível de conhecimento e treinamento gerencial (Capacitação Tecnológica)}

Os resultados neste último quesito ficaram bem distribuídos conforme se pode ver no Gráfico 31. É possível visualizar que a maioria das empresas (60\%) se coloca no nível de conhecimento médio, enquanto $20 \%$ responderam que 'o conhecimento é adquirido na prática. Não há planejamento de treinamentos'. Apenas $10 \%$ (uma empresa) se coloca no nível elevado. Uma empresa não informou. Aqui o resultado geral se apresentou promissor para o APL.
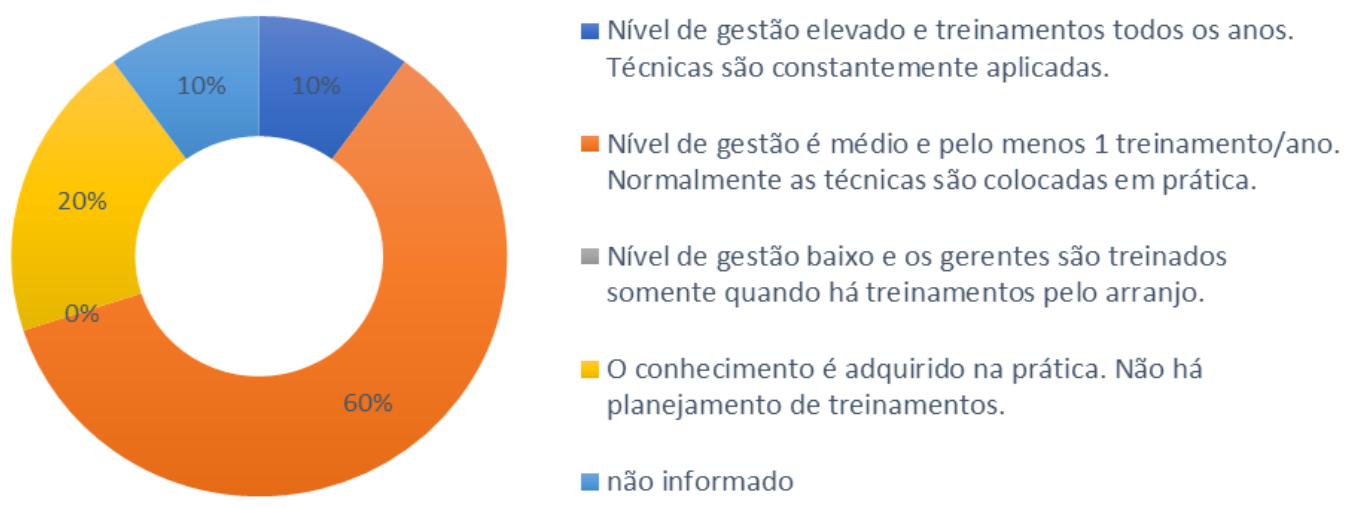

Gráfico 31 - Nível de conhecimento e treinamento gerencial da empresa Fonte: Dados da pesquisa.

Com relação a variável 'Capacitação Tecnológica' (questões do grupo 3.3.8), Mendonça (2008), afirma que o capital humano, a tecnologia e a inovação mobilizados pelo APL, apesar de aparecer como condição básica em algumas atividades, ao mesmo tempo constitui desafio permanente. Há situações em que persistem deficiências de formação profissional ou mesmo de conhecimento de variáveis estratégicas da atividade produtiva na qual o ator está inserido.

Thury et al (2010) ressaltam que as primeiras iniciativas no campo tecnológicoinovativo partiram de empresas privadas nos anos de 1980, tendo em seus quadros pesquisadores, das áreas de farmácia e bioquímica, egressos das universidades locais. Em fins 
dos anos 1990, uma iniciativa que marcou a trajetória do segmento foi a inauguração do Centro de Biotecnologia da Amazônia-CBA ${ }^{32}$.

Em período similar, a academia local iniciou, com apoio do Governo do Estado e da SUFRAMA, os primeiros programas de pós-graduação stricto sensu, como parte de uma estratégia de 'Capacitação Tecnológica' para atuação junto ao CBA e outras instituições científicas, dando suporte à recente bioindústria estadual.

Embora a biotecnologia se destaque na agroindústria, ainda é incipiente na Amazônia, o que levou à criação da Rede Bionorte, com o objetivo de integrar competências para o desenvolvimento de projetos de pesquisa, desenvolvimento, inovação e formação de recursos humanos, com foco na biodiversidade e biotecnologia, visando gerar conhecimentos, processos e produtos que contribuam para o desenvolvimento sustentável da Amazônia Legal. Em 2013 se iniciaram os trabalhos do levantamento de empresas dos APLs para compor o Banco de Dados da Bionorte, com a finalidade de se poder mapear esse contingente e absorver informações relativas ao desempenho econômico das mesmas (ZAU e LASMAR, 2015).

Em uma análise das ligações formais entre organizações de apoio ao sistema de inovação e o APL em estudo, Zau e Lasmar (2015) informam que 82\% das empresas que participaram do PAPPE tinham algum vínculo com universidade ou institutos de pesquisa para o desenvolvimento dos seus projetos, chegando à conclusão que este percentual esteja relacionado aos critérios de avaliação das propostas submetidas ao programa, quais sejam, que as propostas contemplem a participação de mestres e doutores na equipe e que haja parceria com ICT no desenvolvimento do projeto.

\subsection{DA MATRIZ SWOT DE IMPORTÂNCIA DO DESEMPENHO}

Esta análise foi construída a partir da investigação junto às empresas, que participaram da Jornada de Desenvolvimento, evento realizado pelo Governo do Estado em abril/2016, para dar consecução à proposta de implementar sua Nova Matriz Econômica Ambiental. Sua abordagem fundamenta-se na descentralização e crescimento da economia do interior.

A diretriz de implementar uma nova matriz decorre do fato de que a par do conjunto de atividades econômicas decorrentes do PIM, deve-se ampliar e acrescer as atividades econômicas que tem por base os recursos naturais que o Estado dispõe em abundância. Souza $e t$ al (2015) enfatiza que o aproveitamento dos produtos naturais será o ponto de partida para a inserção da economia da região na matriz de um novo modelo de desenvolvimento local.

32 Com prédio próprio, laboratórios instalados e pesquisas em curso, o CBA permanece um impasse: até o momento não existe como pessoa jurídica e não tem modelos de negócios e de gestão formalizados (Thury, 2010). 
O autor acima salienta que o estado do Amazonas ainda é pobre em termos de tecnologia, especialmente em relação às tecnologias voltadas para a valorização dos recursos naturais. Destaca também que hoje existem uma série de atividades no estado que fazem uso da biodiversidade amazônica, porém, com pouco valor agregado.

Para Souza et al (2015), a convergência de algumas fatores como o grande potencial da biodiversidade, programas governamentais de fomento, crescimento do número de incubadoras, entre outros, tem concorrido para que a região se insira na pauta da ciência e dos negócios da biotecnologia, movimentando assim a bioeconomia.

Sendo assim, chama a atenção, para o conceito de bioeconomia, mais relacionado à biotecnologia moderna, que apresenta certa limitação para uso na compreensão da realidade local/regional, uma vez que excluiria grande parte das empresas que fazem uso dos recursos naturais, sendo necessária a apropriação de um conceito mais abrangente, que alcance a amplitude dos negócios que se utilizam da biodiversidade, incluindo atividades de comercialização e/ou beneficiamento de produtos mesmo na forma menos elaborada, mais rústicos, ou concebidos a partir de técnicas tradicionais, com menor grau de valor adicionado.

Apesar de um elenco de pontos relevantes identificados como indispensáveis para o desenvolvimento deste APL, foi possível chegar a um diagnóstico da situação por meio da metodologia da Matriz SWOT. Os resultados foram agrupados por segmento econômico que compõe o cluster, agregando para esta análise informações dos representantes de empresas, a partir de variáveis relevantes e sua caracterização. Ao final da seção apresenta-se a discussão.

\subsubsection{APL DE FITOTERÁPICOS (OU FÁRMACOS)}

\subsubsection{Cadeias Produtivas - familiares ou empresariais}

O resultado sobre a variável 'Cadeias Produtivas - familiares ou empresariais', que envolve como principal demanda a 'organização da cadeia produtiva, ecossistema (organização social e ambiental)', apresentou a seguinte análise de SWOT (Quadro 10).

\begin{tabular}{|c|l|l|}
\hline$\rightarrow$ Pontos & \multicolumn{1}{|c|}{ Positivos } & \multicolumn{1}{c|}{ Negativos } \\
\hline$\downarrow$ Ambiente & \multicolumn{1}{|c|}{ FORÇAS (S) } & \multicolumn{1}{c|}{ FRAQUEZAS (W) } \\
\hline Interno & $\begin{array}{l}\text { 1. Disponibilidade de matéria prima; } \\
\text { 2. Marco regulatório robusto; } \\
\text { 3. Compilação do inventário dos insumos; } \\
\text { 4. Instituições de excelência em C\&T. }\end{array}$ & $\begin{array}{l}\text { 1. Dificuldade de acesso à matéria prima; } \\
\text { 2. Desconhecimento do marco regulatório; } \\
\text { 3. Padronização e consolidação dos dados; } \\
\text { 4. Dificuldade de acesso às tecnologias. }\end{array}$ \\
\hline OPORTUNIDADES (O) & \multicolumn{1}{c|}{ AMEAÇAS (T) } \\
\hline Externo & $\begin{array}{l}\text { 1. Mercados ávidos por mat. prima do } \\
\text { Am; 2. Desenvolvimento do Estado. }\end{array}$ & $\begin{array}{l}\text { 1. Questões fundiárias; 2. Ausência de parceria } \\
\text { entre instituições anuentes; 3. Biopirataria. }\end{array}$ \\
\hline
\end{tabular}

Quadro 10 - Cadeias Produtivas - familiares ou empresariais

Fonte: Dados da pesquisa. 


\subsubsection{Marcos regulatórios}

A variável 'Marcos Regulatórios' sobre a biodiversidade foi analisada considerando-se a questão do acesso ao patrimônio genético e ao conhecimento tradicional associado (CTA), que pode ser cumprido com maior propensão por empresas que possuem mais recursos, ou seja, grandes empresas, recursos humanos especializados e muitos recursos, criando um ambiente pouco favorável com entraves às pequenas empresas da bioeconomia no país (Quadro 11).

\begin{tabular}{|c|c|c|}
\hline$\rightarrow$ Pontos & Positivos & Negativos \\
\hline$\downarrow$ Ambiente & FORÇAS (S) & FRAQUEZAS (W) \\
\hline \multirow[t]{2}{*}{ Interno } & $\begin{array}{l}\text { 1. Existência de RH treinados em áreas vitais } \mathrm{p} / \\
\text { explorar a biodiversidade e apoio aos projetos; } \\
\text { 2. Existência de instituições e empresas no Apl; } \\
\text { 3. Boas ideias para produtos que precisam ser } \\
\text { finalizados; } 4 \text {. Mat. primas da Amazônia. }\end{array}$ & $\begin{array}{l}\text { 1. Falta de conhecimento dos marcos regulatórios } \\
\text { (pesquisadores, empresas); } 2 \text {. Alta complexidade } \\
\text { e tendência à restrição e controle de atividades } \\
\text { (burocratização); } 3 \text {. Tempo e custo do desenv. } \\
\text { dos produtos ( } 3 \text { anos para autorização - CEGEN). }\end{array}$ \\
\hline & OPORTUNIDADES (O) & AMEAÇAS (T) \\
\hline Externo & $\begin{array}{l}\text { 1. Existência de mat. prima em potencial com } \\
\text { espécies florestais não ameaçadas; } 2 \text {. Grande } \\
\text { biodiversidade para desenv. de novos } \\
\text { fitoterápicos, insumos p/ área médica, biomolé- } \\
\text { culas, etc; } 3 \text {. Criação de Farmácias Verdes que } \\
\text { devem funcionar com padrão de qualidade } \\
\text { mínimo; 4. Cenário incentiva aproximação ao } \\
\text { CGEN para ajustar necessidades evidentes; }\end{array}$ & $\begin{array}{l}\text { 1. Risco em relação aos resultados }- \text { é } \\
\text { especulativo (inerentes à própria área); } \\
\text { 2. Próprios procedimentos adotados pelo } \\
\text { CEGEN para acesso ao material genético; } \\
\text { 3. Atual situação regulatória cria um ambiente } \\
\text { hostil para esse tipo de bioeconomia no país e } \\
\text { fora (deslocando investimentos nessa área). }\end{array}$ \\
\hline
\end{tabular}

Quadro 11 - Marcos Regulatórios

Fonte: Dados da pesquisa.

\subsubsection{Mecanismo de atração de investidores e empresas}

Levando-se em conta que um dos principais desafios da atualidade na economia do Estado do Amazonas é a insuficiência de políticas para a criação de um parque industrial na área de bioindústria, o resultado da pesquisa sobre o 'Mecanismo de atração de investidores e empresas', apresentou a seguinte análise (Quadro 12).

\begin{tabular}{|l|c|l|}
\hline$\rightarrow$ Pontos & \multicolumn{1}{|c|}{ Positivos } & \multicolumn{1}{c|}{ Negativos } \\
\hline$\downarrow$ Ambiente & \multicolumn{1}{|c|}{ FORÇAS (S) } & \multicolumn{1}{c|}{ FRAQUEZAS (W) } \\
\hline Interno & $\begin{array}{l}\text { 1. Biodiversidade amazônica; 2. Marca } \\
\text { Amazônia (fonte). }\end{array}$ & $\begin{array}{l}\text { 1. Burocracia: incentivos fiscais, ANVISA; 2. Difi- } \\
\text { culdade de diálogo empresa x academia; 3. Acesso } \\
\text { ao mercado e logística; }\end{array}$ \\
\hline Externo & $\begin{array}{l}\text { OPORTUNIDADES (O) } \\
\text { 1. Fontes de financiamento (Fapeam, FNO, } \\
\text { Afeam, Basa, BNDES); 2. Acesso conheci- } \\
\text { mento produzido c/ partilha dos benefícios. }\end{array}$ & $\begin{array}{l}\text { 1. CGEN (acesso patrimônio genético) e ANVISA; } \\
\text { 2. Carência de especialistas na área; } \\
\text { 3. Falta de decisão política para o setor. }\end{array}$ \\
\hline
\end{tabular}

Quadro 12 - Mecanismo de atração de investidores e empresas

Fonte: Dados da pesquisa. 


\subsubsection{Capacitação de recursos humanos}

Quanto à variável 'capacitação de recursos humanos', que inclui a atividade de 'Promover a capacitação de recursos humanos em todas as fases da cadeia produtiva', os resultados culminaram na análise apresentada (Quadro 13).

\begin{tabular}{|c|c|c|}
\hline$\rightarrow$ Pontos & Positivos & Negativos \\
\hline$\downarrow$ Ambiente & FORÇAS (S) & FRAQUEZAS (W) \\
\hline Interno & $\begin{array}{l}\text { 1. Instituições de pesquisa e ensino bem } \\
\text { estabelecidas; } \\
\text { 2. Sistema de pós-graduação estruturado; } \\
\text { 3. Redes de conhecimento e formação RH; } \\
\text { 4. Presença de instituições de ensino estadual } \\
\text { e federal no interior. }\end{array}$ & $\begin{array}{l}\text { 1. Falta de priorização de distribuição de recursos; } \\
\text { 2. Sistema de ensino sem ênfase na formação } \\
\text { tecnologia nos elos da cadeia produtiva inclusive; } \\
\text { 3. Faltam especialistas em marcos regulatórios; } \\
\text { 4. Custo elevado para a capacitação; } \\
\text { 5. Escassez de mão de obra especializada na gestão } \\
\text { de empresas de bionegócios. }\end{array}$ \\
\hline & OPORTUNIDADES $(\mathrm{O})$ & AMEAÇAS (T) \\
\hline Externo & $\begin{array}{l}\text { 1. Investimentos para promover desenv. } \\
\text { tecnológico ICT/empresas; } \\
\text { 2. Uso de centro de multimídias no interior; } \\
\text { 3. Conhecimento tradicional; } \\
\text { 4. Interação instituições (ensino / empresas) } \\
\text { 5. Aproveitamento dos entes de ensino } \\
\text { p/capacitar a cadeia produtiva interior; }\end{array}$ & $\begin{array}{l}\text { 1. Deficiência na formação de RH em gestão de } \\
\text { plantas industriais; } \\
\text { 2. Redução da oferta de recursos para educação e } \\
\text { formação; } \\
\text { 3. Descontinuidade de políticas para a área; } \\
\text { 4. Deficiência e custo logístico para formar RH } \\
\text { especializado para a Bioindústria no interior. }\end{array}$ \\
\hline
\end{tabular}

Quadro 13 - Capacitação de recursos humanos.

Fonte: Dados da pesquisa.

\subsubsection{Insumos para a produção em larga escala - limitações, oportunidades}

Com a variável 'Insumos para a produção em larga escala - limitações, oportunidades', foi analisada a situação da produção de insumos padronizados em larga escala (Quadro 14).

\begin{tabular}{|l|l|l|}
\hline$\rightarrow$ Pontos & \multicolumn{1}{|c|}{ Positivos } & \multicolumn{1}{c|}{ Negativos } \\
\hline$\downarrow$ Ambiente & \multicolumn{1}{|c|}{ FORÇAS (S) } & \multicolumn{1}{c|}{ FRAQUEZAS (W) } \\
\hline Interno & $\begin{array}{l}\text { 1. Biodiversidade; } \\
\text { 2. Uso das unidades de conservação; } \\
\text { 3. Conhecimento científico e tecnológico do } \\
\text { estado (informações, bancos de dados); } \\
\text { 4. Estrutura técnico-científica do estado. }\end{array}$ & $\begin{array}{l}\text { 1. Enfraquecimento de agências de fomento; 2. } \\
\text { Custo dos insumos para produção; 3. Dificuldade } \\
\text { de padronização da matéria prima; 4. Técnicas } \\
\text { silviculturais (sistema de cultivo); 5. Zoneamento } \\
\text { em escala menor; 6. Falta investimento para o } \\
\text { setor; 7. Irregularidade na produção/oferta de } \\
\text { insumos nas quantidades demandadas pelas } \\
\text { empresas de transformação. }\end{array}$ \\
\hline \multicolumn{1}{|c|}{ OPORTUNIDADES (O) } & \multicolumn{1}{|c|}{ AMEAÇAS (T) } \\
\hline Externo & $\begin{array}{l}\text { 1. Plantio em áreas degradadas; 2. Emprego e e } \\
\text { renda; 3. Novas empresas para insumos } \\
\text { secundários da cadeia produtiva; 4. } 4 .\end{array}$ & $\begin{array}{l}\text { 1. Regulação; } \\
\text { 2. Entraves burocráticos; } \\
\text { 3esenvolvimento de novos produtos. }\end{array}$ \\
\hline
\end{tabular}

Quadro 14 - Insumos para a produção em larga escala - limitações, oportunidades

Fonte: Dados da pesquisa. 


\subsubsection{APL DE FITOCOSMÉTICOS}

\subsubsection{Desenvolvimento de produtos e processos biotecnológicos para a comercialização e}

\section{inserção em cadeias produtivas regionais}

A primeira variável que se sobressaiu no segmento de fitocosméticos foi a do desenvolvimento de produtos e processos biotecnológicos para a comercialização e inserção em cadeias produtivas regionais, que apresentou resultados voltados principalmente à questão da comercialização e posicionamento do cluster no mercado, para inclusão e valorização das cadeias produtivas do Estado do Amazonas, conforme se observa na análise do Quadro 15.

\begin{tabular}{|l|l|l|}
\hline$\rightarrow$ Pontos & \multicolumn{1}{|c|}{ Positivos } & \multicolumn{1}{c|}{ Negativos } \\
\hline$\downarrow$ Ambiente & \multicolumn{1}{|c|}{ FORÇAS (S) } & \multicolumn{1}{c|}{ FRAQUEZAS (W) } \\
\hline Interno & $\begin{array}{l}\text { 1. Zona Franca de Manaus; } \\
\text { 2. Diversidade de matéria prima; } \\
\text { 3. Instituições de C\&T e Marca Amazônia; } \\
\text { 4. Interação com a academia. }\end{array}$ & $\begin{array}{l}\text { 1. Acesso a mercados e fragmentação da produção; } \\
\text { 2. Padronização (insumos), certificação/tecnologia } \\
\text { para conhecimento e proteção da biodiversidade } \\
\text { (agregação de valor); 3. Qualidade dos produtos } \\
\text { representando baixa competitividade. }\end{array}$ \\
\hline Externo & \multicolumn{1}{|c|}{ OPORTUNIDADES (O) } & \multicolumn{1}{c|}{ AMEAÇAS (T) } \\
& $\begin{array}{l}\text { 1. Marca Amazônia; } \\
\text { 2. Diversidade (mat. prima) não explorada; } \\
\text { 4. Interiorização do desenvolvimento; } \\
\text { 5. Mercado (amostras) em redes de hotelaria. }\end{array}$ & $\begin{array}{l}\text { 1. Ausência de política para proteção dos insumos } \\
\text { da biodiversidade Amazônia; } \\
\text { 2. Exploração empírica; } \\
\text { 3. Prospecção tecnológica forte no exterior e fraca } \\
\text { na localidade. }\end{array}$ \\
\hline
\end{tabular}

Quadro 15 - Desenvolvimento de produtos e processos biotecnológicos

Fonte: Dados da pesquisa.

\subsubsection{Cadeias produtivas, geração de emprego e renda para comercialização a partir da} inovação biotecnológica e inserção nas cadeias produtivas regionais

Sobre a questão das cadeias produtivas (familiares ou empresariais), geração de emprego e renda para comercialização a partir da inovação biotecnológica e inserção nas cadeias produtivas regionais, foram revelados dados que endossam, entre outros, a falta de organização social, de condição e de distribuição, conforme análise no Quadro 16.

\begin{tabular}{|l|l|l|}
\hline$\rightarrow$ Pontos & \multicolumn{1}{|c|}{ Positivos } & \multicolumn{1}{|c|}{ Negativos } \\
\hline$\downarrow$ Ambiente & \multicolumn{1}{|c|}{ FORÇAS (S) } & \multicolumn{1}{c|}{ FRAQUEZAS (W) } \\
\hline Interno & $\begin{array}{l}\text { 1. Disponibilidade de matéria prima para } \\
\text { atender a demanda do mercado; } \\
\text { 2. Oportunidade de novos insumos; } \\
\text { 3. Capital científico/conhecimento tradicional }\end{array}$ & $\begin{array}{l}\text { 1. Escala de produção para atender ao mercado; } \\
\text { 2. Qualidade e potencialidade p/ comercializar os } \\
\text { novos insumos e falta de capacitação para coleta; } \\
\text { 3. Falta de transformação para bionegócio. }\end{array}$ \\
\hline Externo & \multicolumn{1}{|c|}{ OPORTUNIDADES (O) } & \multicolumn{1}{c|}{ AMEAÇAS (T) } \\
& $\begin{array}{l}\text { 1. Atração de investimento; } \\
\text { 2. Ativação da economia nos municípios; } \\
\text { 3. Implantação de programas públicos; } \\
\text { 4. Capacidade para atender demandas de } \\
\text { nichos de mercado. }\end{array}$ & $\begin{array}{l}\text { 1. Concorrência entre programas sociais; } \\
\text { 2. Apropriação de ativos amazônicos por grandes; } \\
\text { 3. Quebra de hierarquia social; } \\
\text { 4. Qualidade / Ausência de certificação; } \\
\text { 5. Sazonalidade. }\end{array}$ \\
\hline
\end{tabular}

Quadro 16 - Cadeias produtivas, geração de emprego e renda

Fonte: Dados da pesquisa. 


\subsubsection{Capacitação de recursos humanos e assistência técnica}

Na variável capacitação de recursos humanos e assistência técnica, os resultados convergem para a deficiência de recursos humanos qualificados e em número suficiente para atender a cadeia produtiva, segundo a análise do Quadro 17.

\begin{tabular}{|l|l|l|}
\hline$\rightarrow$ Pontos & \multicolumn{1}{|c|}{ Positivos } & \multicolumn{1}{|c|}{ Negativos } \\
\hline$\downarrow$ Ambiente & \multicolumn{1}{|c|}{ FORÇAS (S) } & \multicolumn{1}{c|}{ FRAQUEZAS (W) } \\
\hline Interno & $\begin{array}{l}\text { 1. Marco legal/Legislação; } \\
\text { 2. Existência de academias, centros e } \\
\text { instituições de pesquisas; } \\
\begin{array}{l}\text { 3. Conhecimento da realidade; } \\
\text { 4. Existência de pequenas e médias empresas; } \\
\text { 5. Existência de incubadoras. }\end{array}\end{array}$ & $\begin{array}{l}\text { 1. Deficiência de assistência técnica qualificada } \\
\text { para atender a demanda interna e externa; } \\
\text { 2. Insuficiência na formação de profissionais na } \\
\text { área de cosméticos; } \\
\text { 3. Distanciamento geográfico das associações de } \\
\text { classe envolvidas no processo; } \\
\text { 4. Deficiência de assistência técnica aos coletores. }\end{array}$ \\
\hline Externo & \multicolumn{1}{|c|}{ OPORTUNIDADES (O) } & \multicolumn{1}{c|}{ AMEAÇAS (T) } \\
& $\begin{array}{l}\text { 1. Utilizar centros de mídias da UEA para } \\
\text { capacitação; 2. Realizar eventos internacio- } \\
\text { nais; 3. Geração de emprego e renda. }\end{array}$ & $\begin{array}{l}\text { 1. Descontinuidade nas políticas públicas; } \\
\text { 2. Instabilidade econômica inibindo a captação de } \\
\text { recursos. }\end{array}$ \\
\hline
\end{tabular}

Quadro 17 - Capacitação de recursos humanos e assistência técnica

Fonte: Dados da pesquisa.

\subsubsection{Mecanismos de atração de investidores e empresas}

A pesquisa da variável mecanismos de atração de investidores e empresas, apresentou de modo geral, uma convergência para a questão das tomadas de decisão para investidores implantarem empregos no Amazonas, conforme se observa a análise do Quadro 19.

\begin{tabular}{|c|c|c|}
\hline$\rightarrow$ Pontos & Positivos & Negativos \\
\hline$\downarrow$ Ambiente & FORÇAS (S) & FRAQUEZAS (W) \\
\hline Interno & $\begin{array}{l}\text { 1. Produtos diferenciados; } \\
\text { 2. Marca "Amazônia"; } \\
\text { 3. Apelo Ambiental; } \\
\text { 4. Instituições de P\&D bem desenvolvidos; } \\
\text { 5. Existência de estudos do APLs. }\end{array}$ & $\begin{array}{l}\text { 1. Fornecedores: sazonalidade, baixa produtivida- } \\
\text { de, falta certificação, capacidade de mão de obra; } \\
\text { 2. Falta de atrativos para investimentos no interior; } \\
\text { 3. Logística (insumos/produto acabado); } 4 . \\
\text { Indisponibilidade de áreas da Suframa para instalar } \\
\text { novas empresas incentivadas em Manaus; } 5 . \\
\text { Limitação de TI, comunicação e falta de energia; } \\
\text { 6. Distância do mercado consumidor. }\end{array}$ \\
\hline & OPORTUNIDADES $(\mathrm{O})$ & AMEAÇAS (T) \\
\hline Externo & $\begin{array}{l}\text { 1. Atrativo p/ exportação com alta do dólar; } \\
\text { 2. Nicho de mercado, aproveitar momento } \\
\text { de instabilidade, voltado p/ produto; } \\
\text { 3. Engajar } 3 \text { esferas de governo na divulga- } \\
\text { ção / promoção das empresas/produtos; }\end{array}$ & $\begin{array}{l}\text { 1. Excesso de concorrência em outros estados; } \\
\text { 2. Instabilidade na taxação da carga tributária nas } \\
\text { três esferas; } \\
\text { 3. Instabilidade na situação política financeira. }\end{array}$ \\
\hline
\end{tabular}

Quadro 18 - Mecanismos de atração de investidores e empresas

Fonte: Dados da pesquisa.

\subsubsection{Produção de insumos em larga escala}

Quanto à produção de insumos em larga escala, observou-se certa ênfase na ausência de produção contínua, conforme a análise dos resultados do Quadro 18. 


\begin{tabular}{|c|c|c|}
\hline$\rightarrow$ Pontos & Positivos & Negativos \\
\hline$\downarrow$ Ambiente & FORÇAS (S) & FRAQUEZAS (W) \\
\hline Interno & $\begin{array}{l}\text { 1. Diversidade de espécies; } \\
\text { 2. Existência de pesquisas; } \\
\text { 3. APLs identificados; } \\
\text { 4. Produtos amazônicos valorizados. }\end{array}$ & $\begin{array}{l}\text { 1. Falta de pesquisa aplicada; } \\
\text { 2. Entraves regulatórios; } \\
\text { 3. Isolamento territorial/logística e falta de energia; } \\
\text { 4. Poucas áreas agricultáveis; }\end{array}$ \\
\hline & OPORTUNIDADES (O) & AMEAÇAS (T) \\
\hline Externo & $\begin{array}{l}\text { 1. A marca Amazonas/Amazônia; } \\
\text { 2. Grande procura por produtos da Amazônia; } \\
\text { 3. Longevidade da população; } \\
\text { 4. Ligeira flexibilidade do CGEN. }\end{array}$ & $\begin{array}{l}\text { 1. Sazonalidade; } \\
\text { 2. Pouca produção de matéria prima primária. }\end{array}$ \\
\hline
\end{tabular}

Quadro 19 - Produção de insumos em larga escala

Fonte: Dados da pesquisa.

A partir da Matriz SWOT do APL de Fitoterápicos e Fitocosméticos apresentada, cujos insumos provém fundamentalmente do uso de espécies amazônicas, foi possível perceber, entre outras questões, a necessidade de estimular e promover organizações sociais no interior com condições de trabalhos adequados para distribuição ordenada e contínua de matérias prima para a sua produção e competências para a comercialização/distribuição de produtos em mercados mais sofisticados do país e do exterior.

Do ponto de vista de oportunidades, é indiscutível o que a região amazônica oferece com a possibilidade de se utilizar uma marca atrativa para os negócios conhecida como 'Amazônia', associada à tendência mundial de vegetalização de fármacos e cosméticos.

Atualmente o Amazonas possui programas, como, por exemplo, PPGBIOTEC e REDEBIONORTE (este atuando em rede dos 9 estados da Amazônia Legal) de pós-graduação de relevância na área de biotecnologia e biodiversidade. No entanto, considerando a sua dimensão e sua disponibilidade de recursos naturais, o número de acadêmicos envolvidos é incipiente para um Estado que deseja tornar estes segmentos importantes para a economia. Além disso, o processo de capacitação deve abordar as competências empresariais/negócios, ou seja, a abordagem de capacitação deve contemplar toda a cadeia de produção e beneficiamento.

Também o SEBRAE/AM, em cooperação com a GIZ ${ }^{33}$, desenvolve conhecimento normativo, tecnológico e mercadológico quanto às oportunidades de negócios sustentáveis e produtivos da cadeia de cosméticos de base florestal madeireira e não madeireira da Região da Amazônia. Como é um projeto regional, as ações são de responsabilidade de cada Sebrae participante, que tem designado um gestor estadual responsável por coordenar o que lhe compete: Mapeamento dos entraves e gargalos da produção de insumos e produtos acabados -

33 GIZ - Deutsche Gesellschaft für Internationale Zusammenarbeit (Agência Alemã de Cooperação Internacional) é uma empresa privada internacional fundada em 1975 por Erhard Eppler e tem hoje como principal acionista o governo federal alemão. A empresa é especializada em projetos de cooperação técnicos e de desenvolvimento sustentável em escala mundial. Sua sede fica na cidade alemã de Eschborn. 
AM; e, mapeamento o conhecimento do segmento cosméticos/TO; Estudos das cadeias produtivas da região e oportunidades de mercado para insumos e produtos acabados/PA; acesso ao patrimônio genético, conhecimento tradicional e repartição de benefícios dos produtos da biodiversidade/AP; Consultoria para assessoria a todos os Sebraes; Identificação de processos para produção de cosméticos na Região AC + RO; Tecnologia e Inovação.

São realizadas ações em cada estado e também reuniões periódicas para compartilhar os conhecimentos desenvolvidos. O conteúdo gerado fica disponível a clientes e parceiros na forma de cartilha e manuais, bem como seminários de divulgação de informações.

Com a expectativa de promover um avanço significativo do APL em foco na economia, nota-se que a produção dos insumos deve ter uma escala que atenda uma oferta assegurada às demandas de mercado. O Estado, como agente ao lado da academia e organizações, deve aproveitar as forças para responder a este desafio, ainda que incipiente, com destaque para a existência de pesquisas em alguns APLs, que buscam se organizar tornando-se confiáveis.

Este crescente mercado, por exemplo, apresentou 1.694 empresas no Brasil em 2008, alcançando US\$37,4 bilhões em faturamento (2010). Desse total, 14 empresas de grande porte representam 73\% do faturamento. Foram legalmente instaladas de 2002 2010, no Brasil, 639 empresas de cosméticos, sendo 3 (três) no Amazonas. Quanto ao consumo do setor no Brasil, Miguel (2012) informa que desde 2006, o país ocupa posição de destaque e o faturamento vem apresentando significativo crescimento ao longo da década. Segundo ABIHPEC (2010), nos últimos 15 anos, a indústria brasileira cresceu 10,4\% e essa expansão é bastante significativa se comparada com outrso setores industriais. Enquanto o segmento de cosméticos obteve taxas de crescimento de 10,4\%, a indústria em geral alcançou 2,7\% e o PIB 3,1\% (IBGE, 2014)

Além das questões relacionadas à capacidade produtiva para atender aos segmentos em foco, é preciso estabelecer processos que simplifiquem a implantação de empreendimentos, escoamento da matéria prima e facilitação da negociação para tornar o produto de boa qualidade, com valor competitivo. Para tal, os stakeholders sugerem a desburocratização dos sistemas de atuação dos órgãos de desenvolvimento, fomento e ações de controle e comando de produção, como também, prover e manter infraestrutura apropriada aos polos produtores para o cultivo, beneficiamento, escoamento, armazenamento e comercialização.

Na comparação com casos de sucesso no Brasil, por exemplo, o BIOTEC do Estado de Minas Gerais (30 empresas; Associação Civil direito privado, FIEMG, SEBRAE, SEDEMG), percebe-se que o Governo do Amazonas precisa se esforçar mais em responder à concentração de atenções mundiais sobre a região, conscientizando-se da sua vocação sob a ótica do desenvolvimento social e comercial e consolidando, também neste aspecto, estratégia 
caracterizada por cooperação técnica, na busca do fortalecimento do intercâmbio e da solidariedade entre os agentes econômicos, para a promoção e defesa dos interesses comuns.

Outro exemplo de sucesso de sistemas produtivos em expansão e consolidação, desta vez na Amazônia, são encontrados atualmente em associação com a fruticultura, especialmente nos municípios de Tomé-Açu e Igarapé-Miri, no Pará, com a produção e o beneficiamento do Açai e de outras frutas liderado por pequenos produtores cooperados (MIGUEL, 2012).

No estado do Amazonas é possível destacar os núcleos em Rio Preto da Eva e os centros de pequena e média escala em Maués e Presidente Figueiredo, com produção de guaraná e intensa articulação dos locais de cultivo com as indústrias processadoras de extratos para a fabricação de concentrados e bebidas e o atendimento dos mercados interno e de exportação

\subsection{DOS RELATÓRIOS DAS EMPRESAS}

A pesquisa nos relatórios das empresas subvencionadas apresentados à FAPEAM, possibilitou observar que propõem estratégias sustentáveis para a obtenção de clientes que optem pelo bem-estar social, a partir de um conceito novo de produtos que apresentem elevados conteúdos nutricionais a partir dos recursos da biodiversidade da Amazônia.

Elas elaboraram projetos voltados às tendências desta nova visão mercadológica, fundamentados em pesquisas tecnocientíficas acuradas, realizadas em parceria com instituições de pesquisa de domínio público por intermédio de clusters interconectados, destacando que possuem diversos pilotos a serem desenvolvidos para a garantia da praticidade e credibilidade de novos itens no mercado, em parceria com assessorias e consultorias externas.

Notou-se que em algumas empresas houve a interconectividade dos clusters com diversas instituições e agências fomentadoras, incluindo AFEAM, Banco do Brasil e Banco da Amazônia. Com uma modelação administrativa e técnica, relatam a expansão de estruturas (hidráulica, elétrica, baixa), contatos com clientes nas regiões Sudeste e Nordeste e vários países Europeus, tais como França, Itália e Portugal, além de oportunidades africanas.

Participaram de eventos, por exemplo, a Feira Internacional da Amazônia e rodada de negócios com maior participação e gabarito técnico. As consultorias técnicas proporcionaram a modificação estrutural necessária para a vistoria, encaminhamento e licenciamento junto à FVS. Com essas atribuições, elaboram atualmente, em média escala, a produção de fitocosméticos e fitoterápicos com alto valor energético, enquadradas pelas normas da ANVISA e com instalações adequadas para a elaboração, projeção e manipulação dos produtos.

Relatam que a produção com insumos regionais é um dos diferenciais que, neste contexto, é de extrema importância o foco do uso sensato da flora amazônica. Com esta visão, 
os recursos humanos empregados (Quadro 20) são impulsionados ao desenvolvimento de atividades que levem a inovações tecnológicas relacionada a processos e aprimoramentos de novos produtos, por meio de pesquisas in loco, envolvendo cooperativas e associações disponibilizadas pelas parceiras, e, treinamentos específicos para boas práticas de fabricação, promovendo a cooperação entre produtor e comercializador final dos produtos.

\begin{tabular}{|c|l|c|}
\hline & Empresa & Nível de empregabilidade \\
\hline 1 & Pronatus do Amazonas Ind. Com. Ltda. & Acima de 7 \\
\hline 2 & Magama Industrial Ltda. & Acima de 7 \\
\hline 3 & Pharmakos D'Amazônia & Acima de 7 \\
\hline 4 & Amazon Ervas & Acima de 7 \\
\hline 5 & Oiram & $1 \sim 2$ \\
\hline 6 & Ecobios Ltda. & $3 \sim 4$ \\
\hline 7 & Temperos da Amazônia & $3 \sim 4$ \\
\hline 8 & Agrosol & $1 \sim 2$ \\
\hline 9 & Loja das Essencias & $3 \sim 4$ \\
\hline 10 & Amazoe Ltda. & \\
\hline
\end{tabular}

Quadro 20 - Modelo alvo PAPPE-Subvenção: Responsabilidade Social

Fonte: Dados da pesquisa obtidos do questionário e/ou relatório da empresa.

O desenvolvimento dos processos e produtos se dá em comunhão com o treinamento de instituições de pesquisas e a sociabilização das cooperativas e associações para a inserção das boas práticas de produção no ambiente florestal (Quadro 21), proporcionando qualidade de vida e ampliação dos desenvolvimentos para a exploração sustentável dos recursos da Amazônia, na busca incessante pela identificação do padrão de identidade e qualidade dos produtos regionais.

Coria e Sterner (2011), salientam que a exploração desordenada da Amazônia se alimenta de direitos imprecisos, avaliação incorreta dos insumos e produtos decorrentes da exploração da floresta, indisponibilidade de informações, acordos de domínio ou de outras formas de poder de mercado e ou decisões de maus investimentos feitos por órgãos estaduais.

\begin{tabular}{|c|l|c|}
\hline & \multicolumn{1}{|c|}{ Empresa } & Instituições colaboradoras \\
\hline 1 & Pronatus do Amazonas Ind. e Com. Ltda. & UFAM \\
\hline 2 & Magama Industrial Ltda. & EMBRAPA \\
\hline 3 & Pharmakos D'Amazônia & EMBRAPA \\
\hline 4 & Amazon Ervas & UFAM \\
\hline 5 & Oiram & UFAM \\
\hline 6 & Ecobios Ltda. & UFAM-CDTECH \\
\hline 7 & Temperos da Amazônia & UFAM \\
\hline 8 & Agrosol & UEA \\
\hline 9 & Loja das Essencias & UFAM \\
\hline 10 & Amazoe Ltda. & U. \\
\hline
\end{tabular}

Quadro 21 - Modelo alvo do PAPPE-Subvenção: Responsabilidade Ambiental Fonte: Dados da pesquisa obtidos do questionário e/ou relatório da empresa. 
A evolução da acumulação de competência tecnológica, para realizar atividades mais complexas de manejo e viabilidade econômica regional parte do interesse nos estudos de impactos socioeconômicos como requisito para a inclusão destas empresas em projetos de subvenção, ocorrendo em diferentes atividades, públicos e mercados, precisamente em composto tecnológico, acrescido da iniciativa, criatividade e visão empreendedora.

Esses procedimentos de adaptação são primordiais para as empresas no processo de definição e fixação da técnica contínua, não simplesmente pelos resultados satisfatórios, mas pela inserção da mudança em sistemas de produção com medição de desempenho, provocando alterações no mercado de fornecedores, possibilitando não apenas o processo de inovação em si, mas, também, por estimular a criatividade e oferecer serviços de utilidade social que respondam às necessidades específicas que o mercado não sabe ou não deseja satisfazer.

Deste modo, as empresas relatam que a prática da inovação é espontânea, legítima e enraizada, ou seja, as empresas identificam-se neste prisma, sendo abertas as observações de seus colaboradores, tornando-a rotineira e envolvida de todos os processos operacionais.

Em síntese, para elas o processo de aprendizagem é contínuo e intrigante, pois a adoção de novos meios incrementais de solução organizacional para os praticados por grande parte do tempo, e adoção de novas conexões interpessoais, aglutina uma barreira interna das suposições empresariais e transforma o fazer "o novo" como mais um concorrente interno das relações empresariais e fazem frente às interferências que já provocaram a falência das instâncias de planejamento e orçamento no setor, pois o abandono da padronização, dos procedimentos administrativos, a desestruturação da funções das políticas de recursos humanos, a persistente descontinuidade de projetos realizados.

É passivo entre as empresas subvencionadas que o uso de uma tecnologia requer, além da aquisição de equipamentos a assimilação de 'know how' de operação. A fase inicial do processo de interação envolve atividades criativas e complexas, gerando mudança técnica incremental para adaptar a tecnologia adquirida às condições específicas e, posteriormente, melhorias contínuas para atingir os desempenhos alcançados nos locais de origem.

Do ponto de vista econômico, as empresas registram que ocorre um crescimento exponencial das vendas proporcionando uma possibilidade de diversidade na cadeia de suprimentos e de distribuição.

Os empreeendedores relatam que inclusão de treinamentos e conjunção de visitas in loco transformam as comunidades nos estudos da gestão dos bens não duráveis utilizados como matéria prima para novos produtos. A estabilização do homem na floresta e a possibilidade de treinamento sobre os benefícios da preservação, culminam na renovação cultural sobre o uso da 
terra e dos métodos extrativistas, como nova aplicabilidade de estudo da cadeia de plantas amazônicas, por exemplo.

As ações de promoção deste mercado estão ligadas a estratégias de cada produto, no entanto, como atualmente os maiores varejistas como as drogarias, supermercados, restaurantes, hotéis, lojas especializadas em alimentos funcionais, estão sempre em busca de redução de custos onde o produto brasileiro concorre principalmente com os países latino americanos, a ideia de um produto regional busca gerar um diferencial de qualidade bastante competitivo, formando parceria com rede varejista local e nacional.

A partir dos recursos captados, relatam que foi possível a adequação de laboratório, aquisição de equipamentos, contratação de funcionário e pesquisadores para a execução da pesquisa. As empresas relatam ainda que as pesquisas demonstram que é possível inovar utilizando recursos florestais com baixo impacto ambiental e um desenvolvimento sustentável.

Com a formação de recursos humanos, que está inserida na parte social, relatam que foi possível repassar conhecimento sobre todo o processo produtivo e principalmente a conscientização sobre a utilização dos recursos naturais como forma de responsabilidade social às várias comunidade e colaboradores.

Alguns dos resultados importantes confirmam o que outras pesquisas similares já apontaram, exemplos: falta de mão de obra qualificada, fragilidade na cooperação; limitação dos produtos ao mercado regional, face aos poucos atributos para competitividade em mercados mais sofisticados; limitação da capacidade inovativa; insuficiência e pouca eficácia das políticas de apoio aos APLS, entre outros.

Para Alves (2015) as organizações modernas atuam em cenários dinâmicos, onde a complexidade e custo de desenvolvimento de produtos, os avanços das novas tecnologias e a necessidade de constantes inovações são fatores que influenciam a competitividade das organizações, o que implica na capacidade de responder as demandas do mercado dentro de custos e tempo limitado, o que geralmente impossibilita empresas que não possuem o conhecimento e competências especificas para acompanharem ou se desenvolverem. 


\section{CONCLUSÃO}

A pesquisa analisou as diversas maneiras como o conceito de APL tem sido compreendido e utilizado por diferentes agentes econômicos e adentrou na reflexão sobre o que foi visto e apoiado no APL de Fitoterápicos e Fitocosméticos do Estado do Amazonas, apresentando um diagnóstico do modelo de investimento do setor público em APLs, a partir da medição da eficiência do desempenho na principal base de informação selecionada, que foi o Programa PAPPE Subvenção/FAPEAM, com foco nas áreas de gestão da produção, qualidade, capital social e ações tecnológicas.

É possível concluir que a medição de desempenho do APL por meio das variáveis escolhidas, possibilita mapear os clusters de empresas e instituições interconectadas e avaliar os resultados alcançados para a implantação das ações de melhoria, que podem ser executadas a partir de recursos públicos subvencionados.

Como conclusão pode-se apontar que as principais necessidades do APL em foco estão relacionadas com escassez de recursos humanos qualificados, baixa produtividade e valor agregado nos produtos, carência de um sistema de medição de indicadores de desempenho (IDs) que apoiem a tomada de decisão e desenvolvimento do arranjo produtivo estudado.

Por outro lado, a análise apontou que $70 \%$ das empresas possuem modelo organizacional utilizado na empresa, o que poderia levar a utilização de IDs, dos quais esta pesquisa incluiu a produtividade. É possível observar que 30\% das empresas não responderam a este quesito porque provavelmente se inclui no grupo das que não utilizam IDs para auxiliar em sua gestão. Isto se deve ao fato de os empresários não conhecerem esses indicadores e também pela falta de pessoas qualificadas para desenvolvê-los. Isto reforça a necessidade de profissionais capacitados em gestão para empresas do APL.

Logo, as empresas carecem de um Sistema de Medição de Desempenho (SMD) para dar suporte ao processo de gestão empresarial com base na responsabilidade socioeconômica, considerando a biodiversidade como recurso econômico potencial. Este resultado remete a uma questão do ponto de vista socioeconômico quanto a Amazônia: a participação do APL em estudo no Fluxo Circular de Riqueza ou do PIB do Amazonas e do Brasil, que é desprezível frente à sua magnitude, e também da incipiente política pública dedicada ao tema.

As empresas também não procuraram informações completas relacionadas ao desenvolvimento do APL, muitas delas se posicionam de forma antagônica. Tem-se uma situação que compromete a tomada de decisão governamental quanto aos investimentos para alavancagem de clusters, o que vem causando prejuízo aos cofres públicos, uma vez que o 
direcionamento dos recursos financeiros disponibilizados por meio de programas de subvenção ou ações institucionais destinadas para as MPEs, como este programa PAPPE/FAPEAM investigado na tese, não retornaram, na maioria dos casos, na forma efetiva de empregabilidade e produtividade.

Os stakeholders não fizeram uso da medição de indicadores e boa parcela dos empresários desconhece este processo e sua importância para o desenvolvimento socioeconômico e ambiental do APL e, consequentemente das empresas. Reitera-se que há uma carência de pessoas qualificadas e preparadas para a implantação e utilização da medição de IDs, incluindo-se ai gestores qualificados em empresas de bionegócios.

Além disso, existe deficiência de gestão, os recursos de tecnologia de informação (TI) são deficientes para atender as necessidades empresariais e em alguns casos há falta de recursos humanos qualificados para explorar todas as suas funções nesta área de TI.

Ficou evidenciado por outro lado que, por intermédio da medição de desempenho é possível obter informações confiáveis para incrementar a competitividade de venda dos produtos, promover a produtividade e qualidade, qualificar pessoas nas áreas de gestão empresarial e operações de manufatura, criando com isso a possibilidade de aumentar o número de pessoas empregadas e sobretudo assegurar maior chance dos empreendimentos serem bem sucedidos e se expandirem.

O trabalho com o APL em foco e suas estratégias abre uma opção ao modelo industrial, ainda hoje com setores econômicos não vinculados diretamente aos recursos florestais. $\mathrm{O}$ Estado do Amazonas possui um plano para o desenvolvimento deste segmento promissor, elaborado via processo endógeno, em que foram reunidas ações previstas, além daquelas que as instituições já empreendem naturalmente por força do mercado.

Neste processo a cooperação G/A/E precisa avançar mais com o APL estudado que, segundo os resultados, apesar de uma pequena atenção, foi capaz de aumentar a produção regional e garantir o incremento de forma significativa, promovendo avanço na geração de renda e empregos.

De um modo geral, o regime tradicional de trabalho e renda está crítico, quer por limitações impostas ao extrativismo, quer pelo alto custo da agricultura convencional, que precisa de manejo e correção dos solos, além de uma política de fomento e crédito ao pequeno e médio produtor, em ritmo superior às suas possibilidades.

A estas condições, adiciona-se o enfraquecimento dos mecanismos regionais de desenvolvimento que poderiam, de maneira progressiva e sistemática, incorporar definitivamente o APL e suas estratégias às políticas implementadas, em particular, por meio 
da inclusão de um número maior de protagonistas que assumam a governança, que atente para: estrutura e natureza da indústria; mecanismos de coordenação, ou seja, como se organizam as relações entre empresas e com o setor público; e, políticas públicas com enfoque em APL.

Então, a cooperação deve ser estimulada, pois as empresas podem reduzir riscos de $\mathrm{P} \& \mathrm{D}$, diversificar produtos, reduzir tempo de lançamento no mercado, ratear custos do projeto, adquirir novas habilidades, introduzir inovações tecnológicas. A academia pode oferecer apoio mais simplificado para pesquisas de longo prazo; auxílio às empresas para produção de novos conhecimentos úteis; ampliação da experiência educacional e oportunidade de emprego para estudantes; possibilidade de interação com engenheiros da indústria; acesso a equipamentos especializados das empresas e divulgação dos trabalhos de pesquisa pela universidade.

Ao admitir uma reorientação em sua matriz econômica (e ambiental) há que se pensar na valorização do homem - educação e reeducação - com o suporte básico necessário para a sustentabilidade potencial do habitat natural. Quanto mais as pessoas tiverem acesso ao conhecimento, mais terão condições de participar ativamente na definição de prioridades no meio social e econômico em que vivem.

É essencial passar para um estágio avançado de APL dentro de um enfoque abrangente que inclua não só os aspectos socioeconômicos, mas, também do meio natural, sem o que não será possível um avanço em um contexto democrático e de justiça social. Para tanto, é necessário estender às comunidades locais estudos e recursos essenciais básicos para a pesquisa e organização do APL de Fitoterápicos (ou Fármacos) e Fitocosméticos, na medida em que este aspecto representa, entre outros, fator de limitação para alavancar o desenvolvimento.

Esses segmentos produtivos têm viabilidade com o aproveitamento dos tradicionais e novos produtos regionais sob novas tecnologias e práticas aplicadas aos usos racionais dos recursos e a incorporação de $\mathrm{P} \& \mathrm{D}$ vinculada aos centros de pesquisa regionais no desenvolvimento de novos bioprodutos.

Por fim, conclui-se que é de suma importância estimular a participação das empresas nos estudos do APL, levando-se em conta que muitas foram contatadas para esta investigação, porém não deram retorno. Um movimento em prol do modelo proposto de acompanhamento da medição de desempenho resultante deste estudo pode contribuir para que o processo de tomada de decisão dos stakeholders, se torne cada vez mais legítimo e justo para os empreendedores que buscam desenvolvimento econômico com responsabilidade social. 


\section{RECOMENDAÇÕES}

A competitividade de Arranjos Produtivos pode ser potencializada por intermédio da eficiência coletiva baseada na formação de alianças conjuntas. Essas alianças não ocorrem exclusivamente pelo interesse econômico, ou pelo menos, não apenas baseado neste interesse, há fatores muitas vezes sociais e ambientais que influenciam neste processo de formação de redes organizacionais.

A capacitação tecnológica empresarial para fins inovativos pode ser alcançada por ações tais como pela formação e qualificação do capital social, pela interação entre atividades comuns com os agentes, com a modernização dos bens de capital empregados na atividade produtiva, no aparelhamento de laboratórios de pesquisa com equipamentos e recursos de qualidade entre outros. O fortalecimento de programas de pós-graduação e de similares nas instituições de ensino superior do Amazonas e a resolução dos impasses do CBA se colocam como condição sine qua non para o avanço da produção com indústrias intensivas em conhecimento científico.

Com base na análise das variáveis de desempenho da eficiência e nas apontadas na Matriz SWOT, o modelo ou instrumento pode se apresentar viável para o acompanhamento e avaliação do APL de Fitoterápicos e Fitocosméticos, com potencial para mitigar e/ou solucionar na prática questões vitais apontadas no estudo, visando a superação de barreiras econômicas e socioambientais (Figura 16).

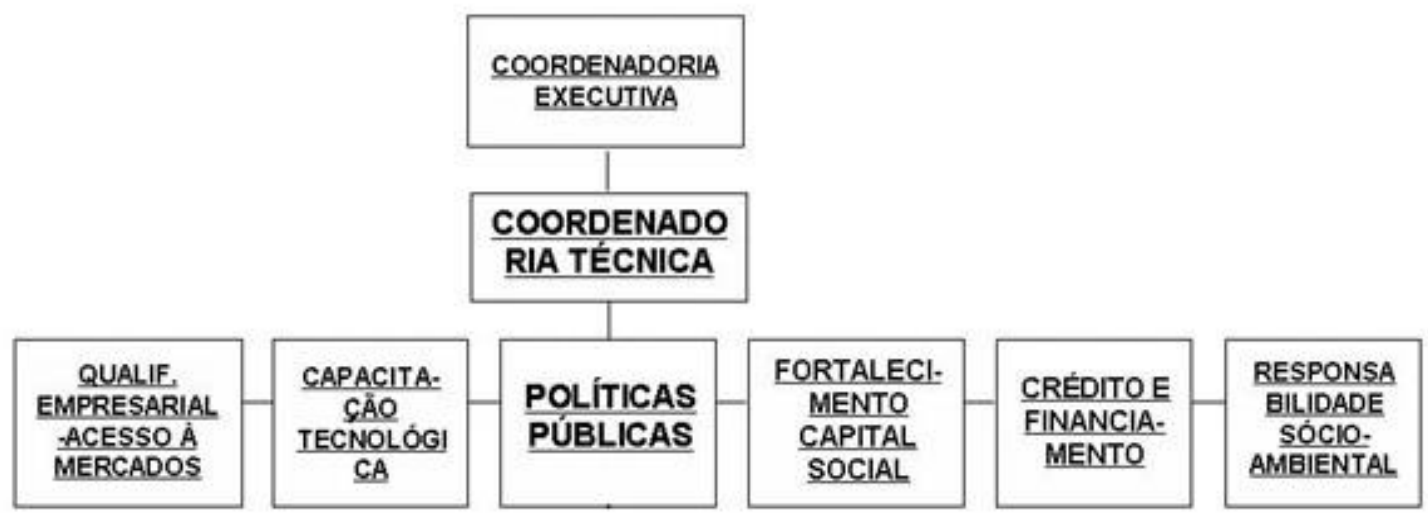

Figura 16 - Modelo de gestão do desempenho para a superação de barreiras do APL Fonte: NEAPL/SEPLAN, 2013.

É plausível postular que as barreiras do APL estudado somente serão superadas por meio da efetiva integração das intervenções pautadas na ótica do desenvolvimento sócioeconômico, que conta com alianças em CT\&I e de experiências bem sucedidas nessas áreas, tornando factível estabelecer estratégias coerentes que visem à superação das atuais demandas em associação aos produtores e empreendedores no estado do Amazonas. 
São muitos os impactos dos circuitos produtivos já existentes nos municípios amazonenses em que se encontram instalados, sejam segmentos vinculados às escalas de produção e integração com pequenos produtores familiares cooperados ou pela introdução de inovações tecnológicas nos sistemas de cultivo e do processamento das matérias primas.

Para que esse cenário seja alcançado de forma consistente, mostra-se vital a constante avaliação da dinâmica socioeconômica associada a outras atividades de alavancagem em que os agentes estejam envolvidos, como, por exemplo, fortalecimento de sistemas produtivos e o desenvolvimento de infraestrutura, incluindo dois temas transversais que devem constituir objeto de ações de fomento: inovação, por meio do apoio às atividades de $\mathrm{P} \& \mathrm{D}$, engenharia e outras competências associadas ao fortalecimento da competitividade; e segundo, o desenvolvimento local/regional, através de investimentos integrados em diferentes escalas territoriais e institucionalidades, priorizando regiões menos desenvolvidas do Amazonas.

Em paralelo deve-se buscar parcerias para a criação de espaços educacionais voltados para a difusão de formas de utilização de novas tecnologias (uso de tecnologias da informação, de novos equipamentos e aplicação de técnicas de gestão administrativa, financeira, e de produção), assim como a implementação de programas de bolsas e maior intercâmbio entre empreendedores e instituições de ensino.

Um caso exemplar nesse contexto de parceria entre universidade e empresa privada, é o da UEA/Samsung com a implantação de um Centro de Treinamento e Capacitação. O Samsung Oceam foi inspirado na arquitetura das grandes empresas de criação espalhadas pelo mundo. Fundamenta-se em tres pilares: desenvolvimento de aplicativos móveis, desenvolvimento de jogos e educação. Tem como objetivo contribuir para a criação de novas empresas (start-ups) para integrar o ecossistema brasileiro de desenvolvimento de novos softwares, aumentando a oferta de aplicativos móveis e jogos eletrônicos para o mercado regional e mundial.

Seria interessante estudar também, meios para que comunidades, cooperativas e empreendedores assumam ou aprofundem gradativamente os rumos do APL em que atuam, em especial na questão da responsablidade socioeconômica. Após estudar como proceder, seria interessante adotar os meios para que tais atores se responsabilizem cada vez mais por ações planejadas no APL, reduzindo o peso do setor público.

No tocante ao desenvolvimento de produtos e processos biotecnológicos para a comercialização e inserção em cadeias produtivas regionais, recomenda-se: criar uma agência de apoio à comercialização; Formar e capacitar profissionais dedicados à gestão de bionegócios apoiados nos recursos naturais e da biodiversidade amazônica; articular a inclusão dos produtos regionais nas grandes cadeias varejistas; incentivar instalação de empresas produtoras dos 
insumos às indústrias; Atrair empresas âncoras de bens finais em áreas afins ao APL, já reconhecidas no mercado nacional e/ou internacional; criar infraestrutura de laboratórios credenciados para realização de testes de eficácia e toxicologia, exigidos pela ANVISA e agências internacionais.

Nas questões de cadeias produtivas, geração de emprego e renda para comercialização a partir da inovação biotecnológica e inserção nas cadeias produtivas regionais, sugere-se uma atualização do inventário e mapeamento; padronização dos processos de coleta e transformação junto às comunidades; integração de programas sociais ofertados aos grupos/atores das cadeias; definição de protocolos dos órgãos reguladores; e, eleição de produtos/insumos mais demandados pelo mercado e criar arranjos para seu desenvolvimento.

Nessa perspectiva de formação, apesar das deficiências, o Estado apoia a formação científica do ensino fundamental ao pós doutorado. Em relação à capacitação de recursos humanos, recomenda-se criar programas de capacitação stricto e latu sensu e de curta duração que contemplem toda a cadeia de produção e de beneficiamento; ampliar e fortalecer intercâmbio entre instituições com interesses similares; promover eventos sobre capacitação da cadeia produtiva (capacitadores e mentores); direcionar pesquisa com perguntas cujas respostas devam ser rápidas para soluções de gargalos na produção e beneficiamento; estabelecer parceria com associações e entidades; e, estimular a criação e funcionamento de incubadoras.

Recomenda-se na questão dos mecanismos de atração de investidores e empresas, reexaminar os processos regulatórios avaliando a possibilidade de incentivos econômicos e fiscais para investimentos nos setores de produção, beneficamente e comercialização de fitoterápicos (ou fármacos) e fitocosméticos.

Observar, ainda, as questões relacionadas à segurança ambiental nos processos produtivos; fortalecer mecanismos de estimulo a fixação de empresas (logística e suporte técnico) e profissionais qualificados no interior do estado; promover polos das principais matérias primas no interior, conforme sua vocação; assegurar agregação de valor aos produtos locais e facilitar a chegada ao mercado; otimizar todos os outros aspectos da cadeia produtiva logística, certificação e questões burocráticas - para apresentar ao Brasil e ao mundo um estado preparado para receber investimentos para a promoção de produtos com a marca Amazônia.

Por fim, recomenda-se a implantação de um plano de ações de inovação contínua com a expectativa de se promover a cooperação empresarial e maior eficiência coletiva do APL. 


\section{REFERÊNCIAS}

AMATO, N. J.. Gestão de Sistemas Locais de Produção e Inovação. Conceitos, princípios e aplicações de indicadores e benchmarkings. Análise e discussão de casos. SP. Atlas, 2009.

ALMEIDA, O. \& ALMEIDA, B.. Caracterização e análise econômica da pesca. Relatório de Pesquisa do Pro-Várzea/ MMA. Ambiente Brasil, 2004.

ALVES, Heleny P. Transferência de conhecimentos e Tecnologias na área de Fitocosméticos no Estado do Amazonas: Perspectivas e Desafios. Tese. Ufam. 2015.

ARAÚJO FILHO, Guajarino. Iniciativas em bionegócio e o programa PAPPE-Subvenção no estado do Amazonas. T\&C Amazônia. Manaus. Ano VIII, n. 19. 2010.

ASSOCIAÇÃO BRASILEIRA DA INDÚSTRIA DE HIGIENE PESSOAL, PERFUMARIA E COSMÉTICOS - ABIHPEC. Informações institucionais e notícias. Disponível em: http://www.abihpec.org.br/. Acesso em: Jun/18.

BARBOSA, Cristiane (Coord.). PAPPE - Quando a pesquisa é um bom negócio. Departamento de Difusão do Conhecimento - DECON. FAPEAM. Manaus. 2012.

BARBOSA, Julimar S. Bichara e Edilson P. Bioindústria, inovação e desenvolvimento: uma análise para o Estado do Amazonas. RECED - Revista eletrônica Ciência e Desenvolvimento. ISSN 2447-7907. UFAM/ICSEZ. Manaus. Janeiro-julho, 2015.

BORGES, M.A.G.. A Tríplice Hélice e o Desenvolvimento do Setor de Tecnologia da Informação no Distrito Federal. UnB. Distrito Federal. Brasília. 2006.

BRITTO, J.; ALBUQUERQUE, E. M. Clusters industriais na Economia Brasileira: uma análise exploratória a partir de dados da RAIS. Estudos Econômicos. São Paulo, v. 32, n. 1, p. 71-102, Jan./Mar. 2002.

BUARQUE, S.C. Ignacy Sachs: o Professor humanista para o século XXI. In: SACHS, Ignacy. Caminhos para o Desenvolvimento Sustentável. $3^{\text {a }}$. ed. Rio de Janeiro: Garamond. 2002.

CABETE, N. P. F; DACOL, S. Identificação das Características dos Arranjos Produtivos Locais. Anais do XXVIII ENEGEP. Rio de Janeiro: ABEPRO, 2008.

CASSIOLATO; LASTRES, Helena M.M.; STALLIVIERI, Fábio; José Eduardo. Arranjos Produtivos Locais: uma alternativa para o desenvolvimento. Experiências de política. Vol. 2. Rio de Janeiro: E-papers, 2010.

CARDOSO; F. MENDONÇA; A. CABRAL; Amilton S. Modelo de Análise de Desempenho de Arranjos Produtivos Locais por meio da relação entre condicionantes e indicadores territoriais. XXXIII Encontro Nacional de Engenharia de Produção. Salvador-BA. 2013.

CAPORALI; P. VOLKER e R. Metodologia de desenvolvimento de arranjos produtivos locais. Projeto Promos - Sebrae - BID: versão 2.0. Brasília: SEBRAE, 2004.

CHIAVEnAtO, I. Gestão de Pessoas: o novo papel dos recursos humanos nas organizações. $3^{\circ}$. Ed. Rio de Janeiro: Elsevier, 2008. 
CORIA, T. Sterne e Jessica. First published online as a Review in Advance on June 2, 2011. The Annual Review of Resource Economics. resource.annualreviews.org. This article's DOI: 10.1146/annurev-resource-083110-120131. Annual Reviews. All rights reserved.

CROCCO, M. A.; GALINARI, R.; SANTOS, F. LEMOS, M. B.; SIMÕES, R. Metodologia de Identificação de Arranjos Produtivos Locais Potenciais. Texto para discussão 212. Belo Horizonte: UFMG/CEDEPLAR, 2003.

COMISSÃO MUNDIAL SOBRE MEIO AMBIENTE E DESENVOLVIMENTO - CMMAD. Nosso futuro comum. $2^{\text {a }}$. ed. Tradução de Our Common Future. Rio de Janeiro: Editora da Fundação Getúlio Vargas, 1991.

DAYCHOUW, Merhi. 40 Ferramentas e Técnicas Gerenciais. 3ª Ed. Brasport. SP. 2007.

DIAS, Cleidson N. Arranjos Produtivos Locais (APLs) como estratégia de desenvolvimento. Revista Desenvolvimento em Questão. Editora Unijuí. Ano 9, n. 17. Jan./Jun. 2011.

DIAS, R. Gestão ambiental: Responsabilidade social e sustentabilidade. 2a . Edição - São Paulo: Atlas, 2011.

ELIAS, Denise. Milton Santos: a construção da geografia cidadã. In: El ciudadano, la globalización y la geografía. Scripta Nova. Revista Electrónica de Geografía y Ciencias Sociales, Universidad de Barcelona, vol. VI, núm. 124. 2002. Acesso em 23 de abril 2017. Disponível em: http://www.ub.es/geocrit/sn/sn-124.htm.

ENRÍQUEZ, Gonzalo Enrique Vásquez. Desafios da Sustentabilidade Amazônica: biodiversidade, cadeias produtivas e comunidades extrativas integradas. Tese de Doutorado. UnB. Brasília. 2008.

FOLHADELA, Guajarino Araújo F., Niomar L. Pimenta, José O. Pereira e Fernando S. Avalação de políticas públicas: o caso da indústria de cosméticos no estado do Amazonas. Biotecnologia e (Bio)Negócio no Amazonas. Manaus: EDUA. 2015.

FUNDAÇÃO DE AMPARO A PESQUISA DO ESTADO DO AMAZONAS. Relatório de Atividades - 2003-2009. Manaus. SECT/FAPEAM. 2010.

GALDÁMEZ, E. V. C. Proposta de um Sistema de Medição de Desempenho para Clusters Industriais de Pequenas e Médias Empresas. Tese - Escola de Engenharia de São Carlos, Universidade de São Paulo. 2009.

GEROlamo, M. C.; CARPinetTi, L. C. R.; SEligeR, G.; GAldÁMEZ, E. V. C. Performance management of regional clusters and SME cooperation networks. International Journal of Business Excellence, v. 1, n. 4, p.457-483, 2008.

HAMMERSCHMIDT, Silvana Sidney Costa Santos e Karina S. A.. A complexidade e a religação de saberes interdisciplinares: contribuição do pensamento de Edgar Morin. Revista Brasileira de Enfermagem, Brasília-DF. 2012. jul-ago; 65(4): 561-5.

HERCULANO, Francisco E.B. Produção Industrial de Cosméticos: o protagonismo da biodiversidade vegetal da Amazônia. Tese. Rede Bionorte. UFAM. Manaus. 2013.

INSTITUTO BRASILEIRO DE GEOGRAFIA E ESTATÍSTICA - IBGE. 2014. Informações estatísticas. Disponível em: 〈http://www.ibge.gov.br>. Acesso em: 10 de junho de 2018. 
INSTITUTO DE ASSESSORIA PARA O DESENVOLVIMENTO HUMANO - IADH. IADH estabelece parceria com CNI. 2010. Acesso em 20 de março de 2018. http://www.iadh.org.br/iadh-estabelece-parceria-com-cni/.

IVO, Anete Brito Leal. Governabilidade e Governança na América Latina: teses e paradoxos. Anais do VII Congresso Internacional do CLAD, Lisboa. Out/2002. 8-11p.

KOTLER, Philip; KELLER, Kevin L. Administração de Marketing: a bíblia do Marketing. 12a . Edição. São Paulo. Prentice Hall Brasil. 2006.

KRAEMER, Maria Elizabeth Pereira. Responsabilidade Social: Um olhar para a sustentabilidade. 2015. Acesso em 23/08/2018: http://www.gestiopolis.com/responsabilidadesocial-um-olhar-para-a-sustentabilidade.

LASMAR, D.J. \& F., F. SANTOS (Org.). Desenvolvimento Regional: Idéias e Estratégias para o Amazonas. Manaus. FUCAPI. 2007.

LASTRES, H. M. M.; CASSIOLATO, J. E. Arranjos Produtivos Locais: uma nova estratégia de ação para o SEBRAE. Glossário de APLs e SPILs. Rede de Pesquisa em Sistemas Produtivos e Inovativos. Rio de Janeiro, 2003. Disponível em: http://www.desenvolvimento.gov.br/arquivos/dwnl_12899323549.pdf. Acesso em: set/2017.

LASTRES, H.M.M; et al.. Interagir para competir: promoção de arranjos produtivos e inovativos no Brasil. Brasília: SEBRAE-FINEP-CNPq, 2003.

MACE, Georgina M. Whose conservation? Changes in the perception and goals of nature conservation require a solid scientific basis. Science 345, 1558 (2014); DOI: 10.1126/science.

MALHI, Y., J. TIMMONS ROBERTS, R.A. BETTS, T.J. KILLEN, C.A. NOBRE. Climate Change. Deforestation and the fate of the Amazon. Science. N. 319: 169-172; 2008.

MARTINS, R. A. Sistemas de medição de desempenho: um modelo para estruturação do uso. Tese. Escola Politécnica da USP. Pós Graduação em Engenharia. São Paulo, 1999.

MATESCO, Paulo H. Schenini e Virene. Economia para não economistas: princípios básicos de economia para profissionais em mercados competitivos. 3. ed.. Senac. RJ. 2008.

MEDEIROS, João Bosco. Redação Científica. 10a . Edição. São Paulo. Atlas, 2008.

MENDONÇA, F.M. Formação, desenvolvimento e estruturação de arranjos produtivos locais da indústria tradicional do Estado de Minas Gerais. $266 \mathrm{f}$. Tese. Universidade Federal do Rio de Janeiro, COPPE, Rio de Janeiro. 2008.

MERICO, L.F.K.. Introdução à Economia Ecológica. Edifurb. Blumenau. 2002.

MEYER-STAMER, J.; HERMES-LIEDTKE. Estratégia de desenvolvimento local e regional: clusters, política de localização e competitividade sistêmica. [S.L.]: ILDES, Friedrich Ebert Stiftung, Set. 2001. Policy Paper, n. 28, p. 1-26.

MIGUEL, Laís M. A Biodiversidade na Indústria de Cosméticos: contexto internacional e mercado brasileiro. Tese. Universidade de São Paulo. 2012. 
MINISTÉRIO DE DESENVOLVIMENTO, INDÚSTRIA E COMÉRCIO EXTERIOR MDIC - BRASIL. Disponível em: http://www.mdic.gov.br/. Acesso em: 01/Jun/17.

MMA - MINISTÉRIO DO MEIO AMBIENTE - BRASIL. Lei da Biodiversidade. Palestra. Manaus. Amazonas. 2015.

MIRANDA, et al, Ires Paula de A. Frutos de Palmeiras da Amazônia. Manaus. Amazonas. MCT/INPA. 2001

MONTANA, Patrick J. CHARNOV, Bruce H. Administração. São Paulo: Ed. Saraiva, 2005.

MUDEN, et al, Lou. Instrumentos Econômicos para Redução do Desmatamento da Amazônia. Rio de Janeiro: Funbio, 2013.

NASCIMENTO, E.P. (Org.). Dilemas e desafios do desenvolvimento sustentável no Brasil. Garamond. Brasília. 2007.

NEELY, A.; ADAMS, C. Perspectives on performance: the performance prism. Cranfield: Center for Business Performance, 2001. (working paper, 7 p.).

OLIVEIRA, Djalma de P.R. Planejamento Estratégico: Conceitos, Metodologias e Práticas. São Paulo: Atlas, 2004.

OLIVEIRA, KARLA F., et al. Processo de medição de desempenho em micro e pequenas empresas de um APL. INGEPRO - Inovação, Gestão e Produção. Novembro de 2010, vol. 02, no. 11. ISSN 1984-6193. www.ingepro.com.br.

PIMENTA, N. A formação de redes de conhecimento nas áreas de fármacos e cosméticos no estado do Amazonas. Palestra. Manaus. FUCAPI. 2014.

PIMENTA, Guajarino A.F.; Dimas J. Lasmar; Francisco Elno B.H.; Niomar. Biotecnologia e (Bio)Negócio no Amazonas. EDUA. Manaus. 2015.

PORTAL LEI GERAL DA MPE. Lei Geral da MPE. Disponível em: http://www.leigeral.com.br/. Acesso em: 6 de Setembro de 2017.

PORTER, M. E. Vantagem competitiva: criando e sustentando um desempenho superior. Rio de Janeiro. Campus, 2000.

REDESIST. Rede de Pesquisa em Sistemas Produtivos e Inovativos Locais. 2009. Disponível em: http://www.redesist.ie.ufrj.br/. Acesso em: 23/04/2017.

SACHS, I. Caminhos para o desenvolvimento sustentável. RJ. Garland, 2002.

SANDRONI, Paulo. Novíssimo Dicionário de Economia. Best Seller. São Paulo. 2000.

SANTANA, A.L. SANTANA e A.C. Mapeamento e análise de arranjos produtivos locais na Amazônia. Teoria e Evidência Econômica, Passo Fundo, v.12, n.22, maio 2004.

SCHMITZ, H. Collective efficiency and increasing return. Cambridge Journal of Economics, v. 24, n. 4, p.465-483, Jul/1999. Disponível: http://proquest.umi.pwdweb. Acesso: ago/2017. 
SEBRAE/AM. Projeto Estruturante de Cosméticos de base florestal da Amazônia. Acesso: 18.02.2017. http://www.sebrae.com.br/sites/PortalSebrae/ufs/ap/artigos/estruturante-cosmeticos-de-base-florestal-da-amazonia,6d55c1878f511510VgnVCM1000004c00210aRCRD

SEBRAE/AM. Encadeamento Produtivo. Manaus. Amazonas. 2015.

SEPLAN. Plano de Desenvolvimento Preliminar do APL de Fitoterápicos e Fitocosméticos - Polo: Manaus. 2013. Disponível: http://www.seplancti.am.gov.br. Acesso: abril/2017.

SEPLANCTI. Relatório da Jornada de Desenvolvimento da Nova Matriz Econômica e Ambiental do Amazonas. Manaus. 2016.

SILVA, Edna Lúcia da; MENEZES, Estera Muszkat. Metodologia da Pesquisa e elaboração de dissertação. $4^{\mathrm{a}}$. ed. rev. atual.. UFSC. Florianópolis, 2005.

SOUZA, J. E. de. Modelo para Avaliação de Arranjo Produtivo Local. Dissertação de Mestrado. Porto Alegre: Universidade Federal do Rio Grande do Sul, 2004.

SOUZA, A.O., CHAVES.M.P.S.R, BARBOSA, R.I., FRANK, N., CLEMENT, C.R. Uso Sustentável dos Ecossistemas Naturais? Cultivo da Acacia mangium Willd. nos lavrados de Roraima. Gestão da Biotecnologia na Amazônia. Manaus: EDUA. 2015.

SOUZA, Guajarino de Araújo F. e Kleber A. A dinâmica da inovação em indústrias de alimentos e bebidas no Amazonas. Biotecnologia e (Bio)Negócio no Amazonas. EDUA. 2015.

SUPERINTENDÊNCIA DA ZONA FRANCA DE MANAUS. Zona Franca de Manaus e Amazônia Ocidental: um Modelo de Desenvolvimento Sustentável. SUFRAMA, 2001.

SUZIGAN, W. GARCIA, R., FURTADO, J. Clusters ou Sistemas Locais de Produção e Inovação: Identificação, Caracterização e Medidas de Apoio. Rio de Janeiro, 2002. Disponível em: http://www.iedi.org.br/admin/pdf/20030516 _ clusters.pdf. Acesso: jul/18.

TAKEDA, Y.; KAJIKAWA, Y.; SAKATA, I.; MATSUSHIMA, K. An analysis of geographical agglomeration and modularized industrial network in a regional cluster. A case study at Yamagata prefecture in Japan. Thechnovation. V.28, p.531-539, 2008.

THOMÉ, T. Políticas públicas ambientais. Jornal Pequeno. Ed. 23.421, Ago/2010. Disponível em: http://www.jornalpequeno.com.br/2010/8/22/politicas-publicas-ambientais-128991.htm. Acesso em: 9 de janeiro de 2017.

THURY, M.V.S, et al. Análise das políticas para APLs no Amazonas. atal. EDUFRN. 2010.

VERGARA, Sylvia Constant. Projetos e Relatórios de Pesquisa em Administração. São Paulo. Atlas, 2009.

XIMENES, A.C. et al. Modelagem Dinâmica do Desmatamento na Amazônia. Bol. Ciênc. Geod., Artigos, Curitiba, v. 14, no. 3, p.370-391, jul-set, 2008.

ZAU, Dimas J. Lasmar e Rosana. Interação entre empresas e ICT: Segmento de produtos naturais (bioindústria regional) e biotecnologia no Amazonas. Gestão da Biotecnologia na Amazônia. Manaus: EDUA. 2015. 


\section{ANEXOS}

Anexo 1: Lista de ações por parceiros no APL Fitoterápicos e Fitocosméticos.

\begin{tabular}{|c|c|c|c|c|}
\hline \multirow{2}{*}{ Número e Nome de ações realizadas } & \multicolumn{3}{|c|}{ Investimentos por parceiros (R\$) } & \multirow{2}{*}{$\begin{array}{l}\text { Ano/ } \\
\text { Período }\end{array}$} \\
\hline & Local & Estadual & Federal & \\
\hline $\begin{array}{l}\text { 1. Desen. de dois prod. fitoter. e um } \\
\text { fitocosm. a partir de espécies amaz. }\end{array}$ & $\begin{array}{c}- \\
\text { Fucapi, } \\
\text { Pronatus }\end{array}$ & $\begin{array}{c}- \\
\text { Sedec (atual } \\
\text { Seplancti) }\end{array}$ & $\begin{array}{c}879.838,48 \\
\text { Finep, Inpa, } \\
\text { Embrapa }\end{array}$ & 2002 a 2007 \\
\hline $\begin{array}{l}\text { 2. Cultivo orgânico de plantas } \\
\text { medicinais }\end{array}$ & $\begin{array}{l}\text { - } \\
\text { Phármacos } \\
\end{array}$ & $\begin{array}{c}- \\
\text { Fapeam } \\
\end{array}$ & Finep, Ufam & 2007 \\
\hline $\begin{array}{l}\text { 3. Qualif. de produtores, uso de } \\
\text { espécies/insumos }\end{array}$ & - & - & Inpa, Basa & 2004 \\
\hline $\begin{array}{l}\text { 4. Fomento à Pesq./Prog. apoio à pesq. } \\
\text { e inov. tec. }\end{array}$ & - & $\begin{array}{l}79.610,20 \\
\text { Fapeam }\end{array}$ & - & 2004 a 2007 \\
\hline $\begin{array}{l}\text { 5. Fomento à Pesq./Prog. Primeiros } \\
\text { projetos }\end{array}$ & - & $\begin{array}{c}29.604,74 \\
\text { Fapeam }\end{array}$ & $\begin{array}{c}29.604,74 \\
\text { Ufam, CNPq }\end{array}$ & 2005 a 2007 \\
\hline $\begin{array}{l}\text { 6. Fomento à Pesq./Prog. Primeiros } \\
\text { Projetos }\end{array}$ & - & $\begin{array}{c}28.618,94 \\
\text { Fapeam }\end{array}$ & $\begin{array}{c}28.618,94 \\
\text { Embrapa, CNPq }\end{array}$ & 2005 a 2007 \\
\hline $\begin{array}{l}\text { 7. Fomento à Pesquisa / Prog. de } \\
\text { Desenv. C\&T }\end{array}$ & - & $\begin{array}{c}35.859,10 \\
\text { Fapeam }\end{array}$ & $\begin{array}{c}35.859,10 \\
\text { Inpa, CNPq }\end{array}$ & 2003 a 2006 \\
\hline $\begin{array}{l}\text { 8. Fomento à Pesquisa / Prog. de } \\
\text { Desenv. C\&T }\end{array}$ & - & $\begin{array}{l}40.959,16 \\
\text { Fapeam }\end{array}$ & $\begin{array}{c}40.959,16 \\
\text { Inpa, CNPq }\end{array}$ & 2003 a 2006 \\
\hline $\begin{array}{l}\text { 9. Fomento à Pesquisa / Prog. de } \\
\text { Desenv. C\&T }\end{array}$ & - & $\begin{array}{l}\text { 40.990,00 } \\
\text { Fapeam }\end{array}$ & $\begin{array}{c}40.990,00 \\
\text { Ufam, CNPq }\end{array}$ & 2003 a 2006 \\
\hline $\begin{array}{l}\text { 10. Fomento à Pesquisa / Prog. de } \\
\text { Desenv. C\&T }\end{array}$ & - & $\begin{array}{l}68.278,95 \\
\text { Fapeam }\end{array}$ & $\begin{array}{l}68.278,95 \\
\text { Inpa, } \mathrm{CNPq}\end{array}$ & 2007 a 2009 \\
\hline $\begin{array}{l}\text { 11. Fomento à Pesquisa / Prog. de } \\
\text { Desenv. C\&T }\end{array}$ & - & $\begin{array}{l}62.149,00 \\
\text { Fapeam }\end{array}$ & $\begin{array}{l}62.149,00 \\
\text { Ufam, Finep }\end{array}$ & 2004 a 2008 \\
\hline $\begin{array}{l}\text { 12. Fomento à Pesquisa / Prog. de } \\
\text { Desenv. C\&T }\end{array}$ & - & $\begin{array}{l}37.910,00 \\
\text { Fapeam }\end{array}$ & $\begin{array}{c}- \\
\text { Ufam }\end{array}$ & 2007 a 2009 \\
\hline $\begin{array}{l}\text { 13. Treinamento em sist. de prod. de } \\
\text { espécie medicinais e aromáticas }\end{array}$ & $\begin{array}{c}1.500,00 \\
\text { Sebrae, Pr. } \\
\text { Manaquiri }\end{array}$ & $\begin{array}{l}500,00 \\
\text { Idam }\end{array}$ & Embrapa & 2008 \\
\hline $\begin{array}{l}\text { 14. Rede de inovação da biodiversidade } \\
\text { / sub-rede de fitoterápicos }\end{array}$ & Fucapi & - & $\begin{array}{c}5.000 .000,00 \\
\text { Mct, Mdic, } \\
\text { Fiocruz }\end{array}$ & 2008 \\
\hline $\begin{array}{lccc}15 . & \text { Rede } & \text { panamericana } & \text { de } \\
\text { biodiversidade }\end{array}$ & - & - & $\begin{array}{c}? \\
\text { CBA, Inpa }\end{array}$ & 2008 \\
\hline 16. Implantação do Polo de Cosméticos & - & Gov. AM & $\begin{array}{c}? \\
\text { Suframa }\end{array}$ & 2009 \\
\hline $\begin{array}{l}\text { 17. Curso técnico biotecnologia/ } \\
\text { cosmetologia; Eng. Bioprocessos }\end{array}$ & $\begin{array}{c}? \\
\text { Fucapi } \\
\end{array}$ & - & - & 2009 \\
\hline $\begin{array}{l}18 . \text { Desenvolvimento de corantes } \\
\text { naturais. }\end{array}$ & - & - & $\begin{array}{c}? \\
\text { CBA, Finep }\end{array}$ & 2008 \\
\hline $\begin{array}{l}19 . \quad \text { Desenvolvimento } \\
\text { Nanoencapsulado }\end{array}$ & $\begin{array}{c}- \\
\text { CT-Pim, } \\
\text { Pronatus, } \\
\text { Ecoamazon }\end{array}$ & - & $\begin{array}{c}\text { ? } \\
\text { Finep, CBA, } \\
\text { Ufam,Unesp } \\
\text { Nanocore }\end{array}$ & 2008 \\
\hline $\begin{array}{l}\text { 20. Prog. Am. de apoio à pesquisa em } \\
\text { MPEs - Pappe Subvenção/Finep }\end{array}$ & $\begin{array}{c}- \\
\text { Sebrae-Am/ } \\
\text { IEL }\end{array}$ & $\begin{array}{l}\text { 2.000.000,00 } \\
\text { Sect/Fapeam } \\
\text { Afeam/Idam }\end{array}$ & $\begin{array}{l}4.000 .000,00 \\
\text { Finep }\end{array}$ & 2008 a 2010 \\
\hline 21. Prog. inovação tecnológica - PIT & - & $\begin{array}{l}2.500 .000,00 \\
\text { Sect/Fapeam }\end{array}$ & - & 2008 a 2010 \\
\hline 22. Prog. de apoio a incubadoras - AM & - & $\begin{array}{l}1.500 .000,00 \\
\text { Sect/Fapeam }\end{array}$ & - & 2008 a 2010 \\
\hline $\begin{array}{l}\text { 23. Prog. } \\
\text { Biotecnológico }\end{array}$ & - & $\begin{array}{c}16.015,00 \\
\text { Sect }\end{array}$ & - & 2008 \\
\hline
\end{tabular}

Fonte: Plano de Desenvolvimento Preliminar do APL de Fitoterápicos e Fitocosméticos. SEPLAN, 2013. 
Anexo 2: Questionário aplicado nas empresas selecionadas do PAPPE-Subvenção

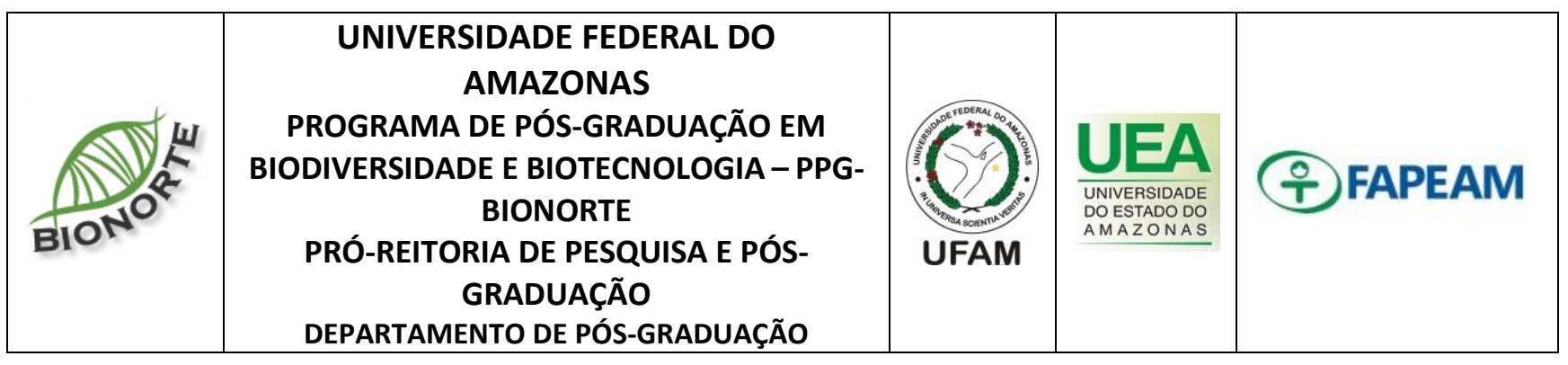

\section{QUESTIONÁRIO PARA ANÁLISE DO DESEMPENHO DE EMPRESAS NO CONTEXTO DOS ARRANJOS PRODUTIVOS LOCAIS}

Esta é uma pesquisa que compõe o projeto de tese intitulado "ARRANJOS PRODUTIVOS E ESTRATÉGIAS PARA APROVEITAMENTO DA BIODIVERSIDADE DO ESTADO DO AMAZONAS", do doutorando Marconde Carvalho de Noronha, do PPG-BIONORTE, sob orientação da Profa. Dra. Ires Miranda e co-orientação da Profa. Dra. Michele Aracaty, que tem por objetivo o levantamento de informações relativas ao desempenho das empresas participantes do instrumento APL enquanto fomento público utilizado oficialmente pelo Governo do Amazonas a partir da criação do Núcleo Estadual de APLs. As questões foram elaboradas com base no modelo alvo proposto pelo Governo Federal, via GTP-APL do MDIC.

O questionário deve ser respondido pela direção da empresa ou pessoa indicada pela mesma; Contém questões de múltipla escolha, em que somente uma resposta pode ser considerada válida.

\section{DADOS GERAIS}

Nome da empresa: Ano de fundação:

E-mail: Cidade/UF:

1. Em que nível de enquadramento sua empresa encontra-se inserida?
( ) Microempresa
( ) Pequena Empresa
( ) Média Empresa
( ) Grande Empresa

2. Como se deu o conhecimento do instrumento "Arranjos Produtos Locais - APLs"?
( ) Grupo de Trabalho
( ) Comitê
( ) Comissão
( ) Núcleo
( ) Outro

3. Em que momento se deu a inserção da empresa no instrumento APL de intervenção governamental em prol do desenvolvimento regional e sustentável do Estado do Amazonas?
( ) Potencialidades Regionais (Suframa/1997)
( ) Plataformas Tecnológicas (MCT/2001)
( ) Arranjos Produtivos Locais (Seplan/2007)
( ) Encadeamento Produtivo (Sebrae/2010)
( ) Nova Matriz Econômica (Seplancti/2016)
( ) Outro

4. A empresa buscava/busca atingir com esta participação seus objetivos no âmbito do mercado:
( ) Local
( ) Regional
( ) Nacional
( ) Internacional

5. Existia/existe uma área específica para lidar com o tema APL dentro da empresa?
( ) Planejamento
( ) P\&D ou C\&T
( ) Negócios/MKT
( ) Outro 


\section{GOVERNANÇA/PARCERIAS}

6. Como foi feita a escolha sobre qual área desenvolver um projeto/parceria em APL?

( ) Nas discussões dos grupos de trabalho formados para esse fim;

( ) Nas reuniões/fórum do Núcleo Estadual de APLs - NEAPL;

( ) A partir das pesquisas desenvolvidas nos diversos segmentos econômicos;

( ) A partir dos encaminhamentos técnicos para a tomada de decisão do gestor envolvido;

( ) Outra:

7. De que forma as empresas, governos e demais entidades da região apoiaram/apoiam o seu negócio?

( ) Na aquisição de produtos, disponibilização direta de infraestrutura, crédito e treinamento para a produção.

( ) Na aquisição de produtos e disponibilização indireta de infraestrutura, crédito e treinamento para a produção.

( ) Na disponibilização direta ou indireta de infraestrutura, crédito e treinamento de mão de obra para a produção em eventuais necessidades.

( ) Não há nenhum tipo de apoio.

8. Quanto ao relacionamento de sua empresa com as demais empresas do setor, é possível afirmar que:

( ) O relacionamento é muito bom, havendo acordos de produção e compartilhamento natural de informações para o desenvolvimento mútuo.

( ) O relacionamento é bom, havendo eventualmente acordos de produção e compartilhamento de informações através da intervenção da governança do arranjo.

( ) O relacionamento é tenso devido à disputa por clientes, não há acordos de produção, e de compartilhamento de informações somente com a intervenção da governança do arranjo.

( ) Não existe nenhum tipo de relacionamento entre sua empresa com as demais.

Comente neste espaço:

9. Ainda sobre o relacionamento entre sua empresa e a governança do arranjo:

( ) Excelente relacionamento entre a empresa e governança do arranjo. A empresa participa do planejamento das atividades do arranjo e beneficia-se dos projetos.

( ) Bom relacionamento entre a empresa e a governança do arranjo, a empresa beneficia-se dos projetos, mas não participa do planejamento das atividades do arranjo.

( ) Relacionamento tenso. A empresa não participa das atividades do arranjo pois não concorda com as decisões tomadas pela governança do arranjo.

( ) A empresa não se relaciona com o arranjo.

Comente neste espaço:

\section{FORNECEDORES}

10. Como é adquirida a matéria prima para o(s) seu(s) produto(s)?

( ) Direto de produtores individuais do interior do estado do Amazonas.

( ) Direto de produtores individuais de outros estados.

( ) De cooperativas e/ou associações do interior do estado do Amazonas.

( ) De cooperativas e/ou associações de outros estados.

( ) De empresas de outros estados.

Comente neste espaço: 
11. No que tange à participação dos fornecedores no desenvolvimento dos negócios de sua empresa:

( ) Os fornecedores são comprometidos com o desenvolvimento da empresa e têm participação direta e ativa nos negócios da empresa.

( ) Os fornecedores assumem seus compromissos de fornecimento de insumos, porém não têm participação nos negócios da empresa.

( ) Os fornecedores apresentam eventuais falhas em assumir seus compromissos com a empresa, dificultando o desenvolvimento, e não têm participação nos negócios da empresa.

( ) Os fornecedores bloqueiam o desenvolvimento da empresa.

Comente neste espaço:

\section{ACESSO AO MERCADO}

12. O modelo alvo propõe que seja realizada a qualificação para acesso ao mercado. Caso tenha acontecido efetivamente esta ação, indique a instituição responsável abaixo:
( ) SEBRAE-AM
( ) FIEAM
( ) CIEAM
( ) SEPROR/IDAM
( )

13. O instrumento APL deve oportunizar à empresa o desenvolvimento de metodologia e tecnologia capaz de ampliar sua produtividade. Caso tenha ocorrido aumento de produtividade indique um percentual aproximado a seguir:
( ) $10 \%$
( ) $20 \%$
( ) $40 \%$
( ) $80 \%$
( ) acima de $100 \%$

14. Em relação à visibilidade da empresa pelo mercado e sociedade em geral, a empresa:

( ) É bem vista pelo crescimento econômico proporcionado à região, pela qualidade de seus produtos e por suas atividades em prol do desenvolvimento regional e sustentável.

( ) É bem vista pelo crescimento econômico proporcionado à região, pela qualidade de seus produtos, mas não desenvolve atividades em prol do desenvolvimento regional e sustentável.

( ) A empresa ainda não é tida como referencial no negócio em que atua, nem desenvolve atividades em prol do desenvolvimento sustentável e social.

( ) A empresa enfrenta dificuldades de estabilização na região devido ao relacionamento com a sociedade (ex.: pela geração de impactos ambientais).

Comente neste espaço:

\section{METODOLOGIA ORGANIZACIONAL E TECNOLOGIAS}

15. Qual a modelo organizacional utilizado na empresa segundo o projeto apresentado para a Subvenção para medir seu desempenho?
( ) PDCA
( ) Balanced Scorecad
( ) Seis Sigma
( ) FOFA
$(1)$

16. Em relação à informatização dos processos administrativos:

( ) Todos os processos administrativos foram informatizados, com utilização de softwares específicos às necessidades da empresa. Uso da internet nos processos.

( ) Somente os processos gerenciais foram informatizados, com utilização das ferramentas básicas e uso da internet nos processos gerenciais.

( ) Existe pelo menos um computador na empresa, sendo utilizado para atividades burocráticas (ex.: emissão de ofícios).

( ) Não existe computador na empresa.

Comente neste espaço: 
17. No que diz respeito à tecnologia de produção implantada na empresa:

( ) Todos os processos produtivos da empresa são automatizados, com participação operacional de mão de obra.

( ) A população é dividida igualmente em processos automáticos e semi-automáticos, com pouca utilização de ferramentas manuais.

( ) A produção é dividida em processos semi-automáticos e manuais.

( ) Toda produção é realizada pela mão de obra com utilização apenas de ferramentas manuais.

Comente neste espaço:

\section{CRÉDITO E FINANCIAMENTO}

18. Em qual programa da FAPEAM de Subvenção aos APLS do Governo do Amazonas, a empresa participou?
( ) PAPPE (1 a Edição/2008)
( ) PAPPE (2a Edição/2010)
( ) PAPPE (3a Edição/2011)
( ) PAPPE-Integração(2012)
( ) Outro

19. Houve obtenção de créditos complementares além do PAPPE-Subvenção?
( ) AFEAM
( ) BASA
( ) BANCO DO BRASIL - DRS
( ) CEF
( )

\section{CAPITAL SOCIAL}

20. O instrumento 'APL' enquanto modelo de desenvolvimento regional e sustentável pode propiciar às empresas condições para gerar emprego e renda. Caso tenham acontecido efetivamente estas condições, indique abaixo o número de contratações ocorridas:
( ) 01 02 empregos ( ) 03 04 empregos ( ) 05 06 empregos ( ) acima de 07 empregos
Comente neste espaço:

21. Quantas famílias foram beneficiadas com o projeto apresentado à Subvenção?
( ) entre 20 a 50
( ) entre 50 e 100
( ) entre 100 e 150
( )entre 150 a 200
Comente neste espaço:

22. Quanto às relações interpessoais constituídas na empresa, é possível dizer que apresenta:

( ) Excelente relacionamento. Os colaboradores sempre motivados participam das decisões da empresa.

( ) Bom relacionamento. Os colaboradores são comprometidos com o trabalho, mas não participam ativamente das decisões da empresa, a menos que sejam solicitados.

( ) Relacionamento tenso. Os colaboradores são desmotivados com os negócios da empresa e apresentam dificuldades em aceitar a liderança constituída.

( ) Relacionamento difícil. Os colaboradores não são comprometidos com o trabalho.

Comente neste espaço:

\section{CAPACITAÇÃO TECNOLÓGICA}

23. O modelo de APLs propõe a capacitação dos recursos humanos da empresa? Caso tenha acontecido efetivamente esta ação, indique a instituição responsável abaixo:
( ) CETAM
( ) IFAM
( ) UEA
( ) UFAM
( ) SESCOOP/OCB
( )

24. Quanto ao nível de conhecimento técnico adquirido pelos colaboradores de sua empresa: 
( ) Assimilaram bem as técnicas de produção e esses treinamentos são disponibilizados todos os anos. Aplicam os conhecimentos e inovam constantemente.

( ) Assimilaram bem as técnicas de produção dos produtos existentes e há pelo menos um treinamento por ano. Normalmente aplicam as práticas e inovam anualmente.

( ) Os colaboradores são treinados somente quando treinamentos são disponibilizados pelo arranjo. Normalmente não aplicam as práticas e há mais de dois anos não há produtos novos.

( ) O conhecimento é adquirido na prática, não havendo planejamento de treinamento. Há anos não há produtos novos.

Comente neste espaço:

25. Em relação ao nível de conhecimento e treinamento gerencial da empresa:

( ) O nível de conhecimento em gestão é elevado e treinamentos internos e externos são disponibilizados todos os anos. As técnicas são constantemente aplicadas.

( ) O nível de conhecimento em gestão é médio e há pelo menos um treinamento interno por ano. Normalmente as técnicas são colocadas em prática.

( ) O nível de conhecimento em gestão é baixo e os gerentes são treinados somente quando treinamentos são disponibilizados pelo arranjo.

( ) O conhecimento é adquirido na prática. Não há planejamento de treinamentos.

Comente neste espaço: 